Supporting Information

\title{
Catalyst Design Principles Enabling Intermolecular Alkene-Diene [2+2] Cycloaddition and Depolymerization Reactions
}

\author{
Megan Mohadjer Beromi, ${ }^{1}$ Jarod M. Younker, ${ }^{2}$ Hongyu Zhong, ${ }^{1}$ Tyler P. Pabst, ${ }^{1}$ and Paul J. \\ Chirik $^{1 *}$ \\ ${ }^{1}$ Department of Chemistry, Frick Laboratory \\ Princeton University, Princeton, NJ 08544, USA \\ ${ }^{2}$ ExxonMobil Chemical Company, Baytown, TX 77520, USA \\ pchirik@princeton.edu
}

\section{Table of Contents}

I. General Considerations $\quad$ S3

II. Preparation or Identification of Metal Diolefin and Metallacyclic Complexes $\quad$ S5

Preparation of (PNP)Fe(s-cis $\left.\mathrm{C}_{4} \mathrm{H}_{6}\right) \quad$ S5

Preparation of (PNN)Fe(s-cis $\left.\mathrm{C}_{4} \mathrm{H}_{6}\right)$

Preparation of $\left({ }^{\mathrm{Me}(\mathrm{Ph})} \mathrm{PDI}\right) \mathrm{Fe}\left(\right.$ trans $\left.\mathrm{C}_{4} \mathrm{H}_{6}\right) \quad \mathrm{S} 11$

Preparation of (MePDI)Ru(s-trans $\mathrm{C}_{4} \mathrm{H}_{6}$ ) $\quad \mathrm{S} 14$

Preparation of (MePDI)Ru(s-trans E-piperylene) $\quad \mathrm{S} 16$

NMR-Scale Synthesis and Identification of $1 \quad S 18$

NMR-Scale Synthesis and Identification of $2 \quad$ S22

III. General Procedure for the [2+2] Cycloaddition of Dienes and Ethylene S24

IV. Experiments Relevant to Diene Disposition $\quad$ S25

CSD Search Criteria and Data $\quad$ S25

Trigonal Bipyramidal vs. Square Pyramidal Bond Deviation Analysis $\quad$ S26

Stoichiometric Reactivity of (PNP)Fe $\left(s-c i s \mathrm{C}_{4} \mathrm{H}_{6}\right)$ with Ethylene

Stoichiometric Reactivity of $(\mathrm{PNN}) \mathrm{Fe}\left(\mathrm{s}-\mathrm{Cis} \mathrm{C}_{4} \mathrm{H}_{6}\right)$ with Ethylene $\quad \mathrm{S} 31$

Catalytic Competence of (PNP)Fe $\left(s-c i s \mathrm{C}_{4} \mathrm{H}_{6}\right)$ in [2+2] Cycloaddition $\quad \mathrm{S} 33$

Catalytic Competence of $(\mathrm{PNN}) \mathrm{Fe}\left(\mathrm{s}-\mathrm{Cis} \mathrm{C}_{4} \mathrm{H}_{6}\right)$ in [2+2] Cycloaddition $\quad \mathrm{S} 34$

V. Experiments Relevant to Diene Dynamics $\quad$ S35

Variable Temperature NMR of ( $\left.{ }^{\text {Me }} \mathrm{PDI}\right) \mathrm{Fe}\left(s\right.$-trans $\left.\mathrm{C}_{4} \mathrm{H}_{6}\right)$

Variable Temperature NMR of ( $\left.{ }^{\mathrm{Me}(\mathrm{Ph})} \mathrm{PDI}\right) \mathrm{Fe}\left(\right.$ s-trans $\left.\mathrm{C}_{4} \mathrm{H}_{6}\right)$ 
Exchange Experiments of ( $\left.{ }^{\mathrm{Me}} \mathrm{PDI}\right) \mathrm{Fe}\left(\mathrm{s}\right.$-trans $\left.\mathrm{C}_{4} \mathrm{H}_{6}\right)$ with Butadiene- $d_{6}$

VI. Experiments Relevant to Oxidative Cyclization S42

Exchange Experiments of ( $\left.{ }^{\mathrm{Me}} \mathrm{PDI}\right) \mathrm{Ru}\left(s\right.$-trans $\left.\mathrm{C}_{4} \mathrm{H}_{6}\right)$ with Butadiene- $d_{6} \quad \mathrm{~S} 42$

Stoichiometric Reactivity of of ( $\left.{ }^{\mathrm{Me} P D I}\right) \mathrm{Ru}\left(s\right.$-trans $\mathrm{C}_{4} \mathrm{H}_{6}$ ) with Ethylene $\mathrm{S43}$

VII. Experiments Relevant to Reductive Elimination $\quad$ S44

Stoichiometric Reactivity of ( $\left.{ }^{\mathrm{Me}} \mathrm{PDI}\right) \mathrm{Fe}\left(\mathrm{s}\right.$-trans $\mathrm{C}_{4} \mathrm{H}_{6}$ ) with ${ }^{13} \mathrm{C}$-Labeled Ethylene $\quad \mathrm{S} 44$

Stoichiometric Reactivity of (MePDI)Ru(s-trans E-piperylene) with ${ }^{13} \mathrm{C}$-Labeled Ethylene

Stoichiometric Reactivity of 1 with CO S51

Catalytic Competence of (MePDI)Ru(s-trans E-piperylene) in [2+2] Cycloaddition S53

Stoichiometric Reactivity of 1 with ${ }^{13} \mathrm{C}$-Labeled Ethylene Under Irradiation $\quad$ S55

Catalytic Competence of (MePDI)Ru(s-trans E-piperylene) in [2+2] Cycloaddition Under

Irradiation $\quad$ S58

VIII. Experiments Relevant to Retro-[2+2] Cyclization S59

Identification of Speciation of [Fe] in the Retro-Cyclization of Propenylcyclobutane S59

Attempted Thermal Retro-Cyclization of $1 \quad$ S61

Photoinduced Retro-Cyclization of 1

IX. Computational Details $\quad$ S63

Geometry Optimizations as a Function of Plane Angle $\quad$ S63

Calculations on Reaction Spin Surface $\quad$ S63

X. Crystallographic Data $\quad S 65$

Crystallographic Data for (PNP)Fe(s-cis $\left.\mathrm{C}_{4} \mathrm{H}_{6}\right) \quad S 65$

Crystallographic Data for (PNN)Fe(s-cis $\left.\mathrm{C}_{4} \mathrm{H}_{6}\right) \quad S 66$

Crystallographic Data for ( $\left.{ }^{\mathrm{Me}(\mathrm{Ph})} \mathrm{PDI}\right) \mathrm{Fe}\left(\right.$ trans $\left.\mathrm{C}_{4} \mathrm{H}_{6}\right)$

Crystallographic Data for ( $\left.{ }^{M e} \mathrm{PDI}\right) \mathrm{Ru}($ s-trans E-piperylene) $\quad$ S68

Crystallographic Data for $2 \quad$ S69

$\begin{array}{ll}X I . \text { References } & \text { S70 }\end{array}$ 


\section{General Considerations}

All air- and moisture-sensitive manipulations were carried out using vacuum line, Schlenk and cannula techniques or in an MBraun inert atmosphere (nitrogen) dry box unless otherwise noted. All glassware was stored in a pre-heated oven prior to use. The solvents used for air- and moisture-sensitive manipulations were dried and deoxygenated using literature procedures. ${ }^{1}$ Butadiene, butadiene- $d_{6}$, ethylene, and ${ }^{13} \mathrm{C}$-labeled ethylene were purchased in reagent grade from either Matheson or Aldrich. The butadiene was deoxygenated by stirring vigorously over powderized BASF B3-11G copper catalyst ( $5 \times 3 \mathrm{~mm}$ tablets) at room temperature for 48 hours, then vacuum transferred into a thick-walled glass vessel containing calcium hydride. The butadiene was stirred over calcium hydride at room temperature for at least 24 hours and degassed before use. Ethylene was stored over activated $4 \AA$ molecular sieves for at least 24 hours before use. Labeled gases were stored in thick-walled glass vessels and used as received. Piperylene (52\% s-trans E-piperylene, as a mixture of s-trans E/Z piperylene and cyclopentene) was supplied by Firmenich, dried over calcium hydride, and stored in the glove box at $-35^{\circ} \mathrm{C}$. The following compounds were prepared according to literature procedures: vinylcyclobutane, ${ }^{2} E$ propenylcyclobutane, ${ }^{3}$ magnesium butadiene, ${ }^{4} \quad\left({ }^{\mathrm{Me}} \mathrm{PDI}\right) \mathrm{FeCl}_{2},{ }^{5} \quad\left({ }^{\mathrm{Me}} \mathrm{PDI}\right) \mathrm{Fe}\left(\mathrm{s}\right.$-trans $\left.\mathrm{C}_{4} \mathrm{H}_{6}\right),{ }^{2},{ }^{6}$ $\left({ }^{\text {Me}} \mathrm{PDI}\right) \mathrm{Fe}\left(\right.$ s-trans E-piperylene), $\left.{ }^{3}\left({ }^{\mathrm{Me}(\mathrm{Ph})} \mathrm{PDI}\right) \mathrm{FeCl}_{2},{ }^{7} \mathrm{PNPFeBr},{ }^{8} \mathrm{PNNFeCl}_{2},{ }^{9}{ }^{\mathrm{Me}} \mathrm{PDI}\right) \mathrm{RuCl}_{2} .{ }^{10}$

${ }^{1} \mathrm{H}$ and ${ }^{13} \mathrm{C}$ NMR spectra were recorded on Bruker NanoBay 300, Varian iNova 400, or Bruker Avance III 500 spectrometers operating at $300.13 \mathrm{MHz}, 399.80 / 100.54 \mathrm{MHz}$, and $500.46 / 125.86$ $\mathrm{MHz}$, respectively. All ${ }^{1} \mathrm{H}$ and ${ }^{13} \mathrm{C}$ NMR chemical shifts are reported in ppm relative to $\mathrm{SiMe}_{4}$ using the ${ }^{1} \mathrm{H}$ (benzene- $d_{6}: 7.16 \mathrm{ppm}$ ) and ${ }^{13} \mathrm{C}$ (benzene- $d_{6}: 128.06 \mathrm{ppm}$ ) chemical shifts of the solvent as a standard. ${ }^{1} \mathrm{H}$ NMR data for diamagnetic compounds are reported as follows: chemical shift, multiplicity $(\mathrm{s}=$ singlet, $\mathrm{d}=$ doublet, $\mathrm{t}=$ triplet, $\mathrm{q}=$ quartet, $\mathrm{p}=$ pentet, $\mathrm{br}=$ broad, $\mathrm{m}=$ multiplet, app $=$ apparent, obsc $=$ obscured $)$, coupling constants $(\mathrm{Hz})$, integration. ${ }^{13} \mathrm{C}$ NMR data for diamagnetic compounds are reported by their chemical shift. 
Zero-field ${ }^{57} \mathrm{Fe}$ Mössbauer spectra were recorded on a SEE Co. Mössbauer spectrometer (MS4) at $80 \mathrm{~K}$ in constant acceleration mode. ${ }^{57} \mathrm{Co} / \mathrm{Rh}$ was used as the radiation source. WMOSS software ${ }^{11}$ was used for the quantitative evaluation of the spectral parameters (least-squares fitting to Lorentzian peaks). The temperature of the sample was controlled by a Janis Research Co. CCS-850 He/ $/ \mathrm{N}_{2}$ cryostat within an accuracy of $0.3 \mathrm{~K}$. Isomer shifts were determined relative to $\alpha$-iron at $298 \mathrm{~K}$.

Single crystals suitable for X-ray diffraction were coated with polyisobutylene oil in a drybox, transferred to a nylon loop and then quickly transferred to the goniometer head of a Bruker SMART APEX DUO diffractometer equipped with a molybdenum X-ray tube $(\lambda=0.71073 \AA)$ and a Cu X-ray tube $(\lambda=1.54178 \AA)$. Preliminary data revealed the crystal system. The data collection strategy was optimized for completeness and redundancy using the Bruker COSMO software suite. The space group was identified, and the data were processed using the Bruker SAINT+ program and corrected for absorption using SADABS. The structures were solved using direct methods (SHELXS) completed by subsequent Fourier synthesis and refined by full-matrix leastsquares procedures. Elemental analyses were performed at Robinson Microlit Laboratories, Inc., in Ledgewood, NJ.

UV-Visible absorption spectra were recorded on a Cary 60 UV-Vis spectrometer (Agilent Technologies, Santa Clara, California) using $1 \mathrm{~cm}$ cuvettes fitted with Teflon sealed caps. Solutions were prepared and sealed in the glove box prior to analysis. Irradiation experiments were conducted using two Kessil ${ }^{\mathrm{TM}} \mathrm{H}-150$ blue lamps ( $30 \mathrm{~W}, 427 \mathrm{~nm}$ ), with the entire apparatus covered by a cardboard box. The set up was cooled by two small fans (Holmed HNF0410A) and achieved a maximum temperature of $35^{\circ} \mathrm{C}$.

Information for DFT calculations are detailed in Section IX. Computational Details. 


\section{Preparation or Identification of Metal Diene and Metallocyclic Complexes}

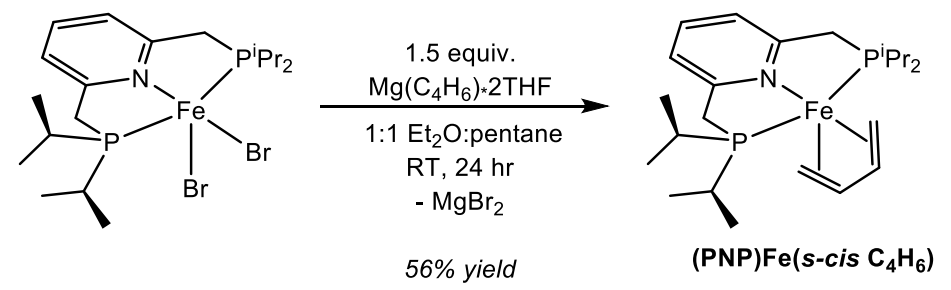

Preparation of (PNP)Fe(s-cis $\mathrm{C}_{4} \mathrm{H}_{6}$ ). To a $20 \mathrm{~mL}$ scintillation vial containing a stir bar in the glove box was added $0.190 \mathrm{~g}(0.342 \mathrm{mmol})$ of $(\mathrm{PNP}) \mathrm{FeBr}_{2}$ and $0.114 \mathrm{~g}(0.513 \mathrm{mmol}, 1.5$ equiv.) of magnesium butadiene. $2 \mathrm{~mL}$ of pentane, followed by $2 \mathrm{~mL}$ of $\mathrm{Et}_{2} \mathrm{O}$ were added to the vial resulting in an instantaneous color change to a dark blue solution. The vial was sealed and the contents were stirred vigorously at room temperature in the glove box for 24 hours. The contents were then filtered through a pad of Celite after which the filtrate was evaporated to dryness. The dark blue residue was taken up in minimal $(\sim 1 \mathrm{~mL})$ pentane and recrystallized at $-35^{\circ} \mathrm{C}$ to yield $0.086 \mathrm{~g}$ (56\% yield) of (PNP)Fe(s-cis $\mathrm{C}_{4} \mathrm{H}_{6}$ ) as a deep blue crystalline solid. Crystals suitable for X-ray diffraction were obtained from a concentrated diethyl ether solution at $-35{ }^{\circ} \mathrm{C}$. Anal Calc'd for $\mathrm{C}_{23} \mathrm{H}_{41} \mathrm{FeNP}_{2}$ : C, 61.47; H, 9.20; N, 3.12. Found: C, 61.07; H, 9.18; N, 2.93. ${ }^{1} \mathrm{H}$ NMR (400 MHz, $\left.\mathrm{C}_{6} \mathrm{D}_{6}, 25^{\circ} \mathrm{C}\right): \delta$ 6.53-6.49 (m, 2H), $6.34(\mathrm{~d}, J=6.5 \mathrm{~Hz}, 1 \mathrm{H}), 5.50(\mathrm{br} \mathrm{s}, 1 \mathrm{H}), 4.88(\mathrm{br} \mathrm{s}, 1 \mathrm{H}), 3.49$ (dd, $J=15.7,8.4 \mathrm{~Hz}, 1 \mathrm{H}), 3.33(\mathrm{~d}, J=14.3 \mathrm{~Hz}, 1 \mathrm{H}), 3.11(\mathrm{dd}, J=16.1,3.4 \mathrm{~Hz}, 1 \mathrm{H}), 3.01(\mathrm{dd}, J=$ 14.1, $9.3 \mathrm{~Hz}, 1 \mathrm{H}), 2.66(\mathrm{~m}, 1 \mathrm{H}), 2.30(\mathrm{~m}, 1 \mathrm{H}), 2.17(\mathrm{~m}, 1 \mathrm{H}), 1.47-1.41(\mathrm{~m}, 11 \mathrm{H}), 1.23(\mathrm{dd}, J=$ 11.9, 7.5 Hz, 3H), 1.13-1.05 (m, 9H), 0.96 (br s, 1H), 0.74 (dd, $J=7.7,1.7 \mathrm{~Hz}, 3 \mathrm{H}$ ), 0.66 (dd, $J=$ $12.6 \mathrm{~Hz}, 7.3 \mathrm{~Hz}, 3 \mathrm{H}), 0.25$ (d, J = 6.0 Hz, 1H), $-1.47(\mathrm{t}, J=7.3 \mathrm{~Hz}, 1 \mathrm{H}),-1.90(\mathrm{t}, J=8.4 \mathrm{~Hz}, 1 \mathrm{H})$. The ${ }^{1} \mathrm{H}$ NMR spectrum is given in Figure S1A. ${ }^{31} \mathrm{P}\left\{{ }^{1} \mathrm{H}\right\} \mathrm{NMR}\left(202 \mathrm{MHz}, \mathrm{C}_{6} \mathrm{D}_{6}, 25^{\circ} \mathrm{C}\right): \delta$ 104.2, 82.0. The ${ }^{31} \mathrm{P}\left\{{ }^{1} \mathrm{H}\right\}$ NMR spectrum is given in Figure S1B. ${ }^{13} \mathrm{C}\left\{{ }^{1} \mathrm{H}\right\} \mathrm{NMR}\left(101 \mathrm{MHz}, \mathrm{C}_{6} \mathrm{D}_{6}\right) \delta 164.87$, $164.78,164.76,164.72,164.68,164.66,164.61,128.30,127.82,117.91,117.84,114.86,114.80$, $82.20,77.17,77.13,44.54,44.41,43.96,43.83,35.37,35.27,35.18,35.08,30.24,29.36,29.32$, $28.84,28.62,27.86,27.77,27.16,21.71,21.66,21.08,21.03,20.83,20.79,20.76,20.41,20.35$, $20.14,19.15,18.71,18.64,16.94,16.85$. The ${ }^{13} \mathrm{C}\left\{{ }^{1} \mathrm{H}\right\}$ NMR spectrum is given in Figure S1C. 
Solid-state Mössbauer $(80 \mathrm{~K}): \delta=0.38 \mathrm{~mm} \mathrm{~s}^{-1},\left|\Delta \mathrm{E}_{Q}\right|=1.85 \mathrm{~mm} \mathrm{~s}^{-1}$. The Mössbauer spectrum is reported in Figure S1D.

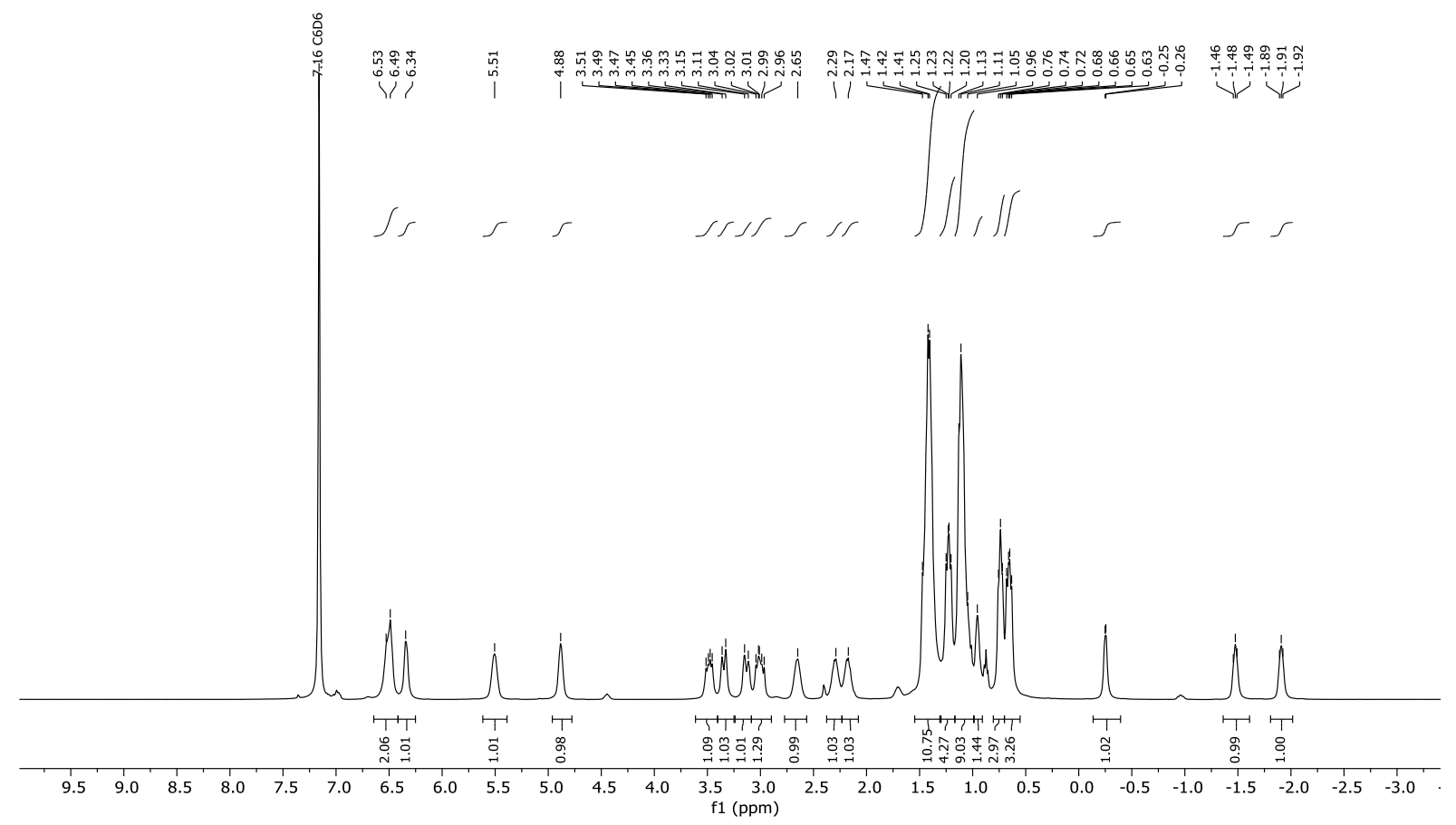

Figure S1A. ${ }^{1} \mathrm{H}$ NMR (400 MHz, $\left.\mathrm{C}_{6} \mathrm{D}_{6}, 25^{\circ} \mathrm{C}\right)$ spectrum of (PNP)Fe(s-cis $\mathrm{C}_{4} \mathrm{H}_{6}$ ).
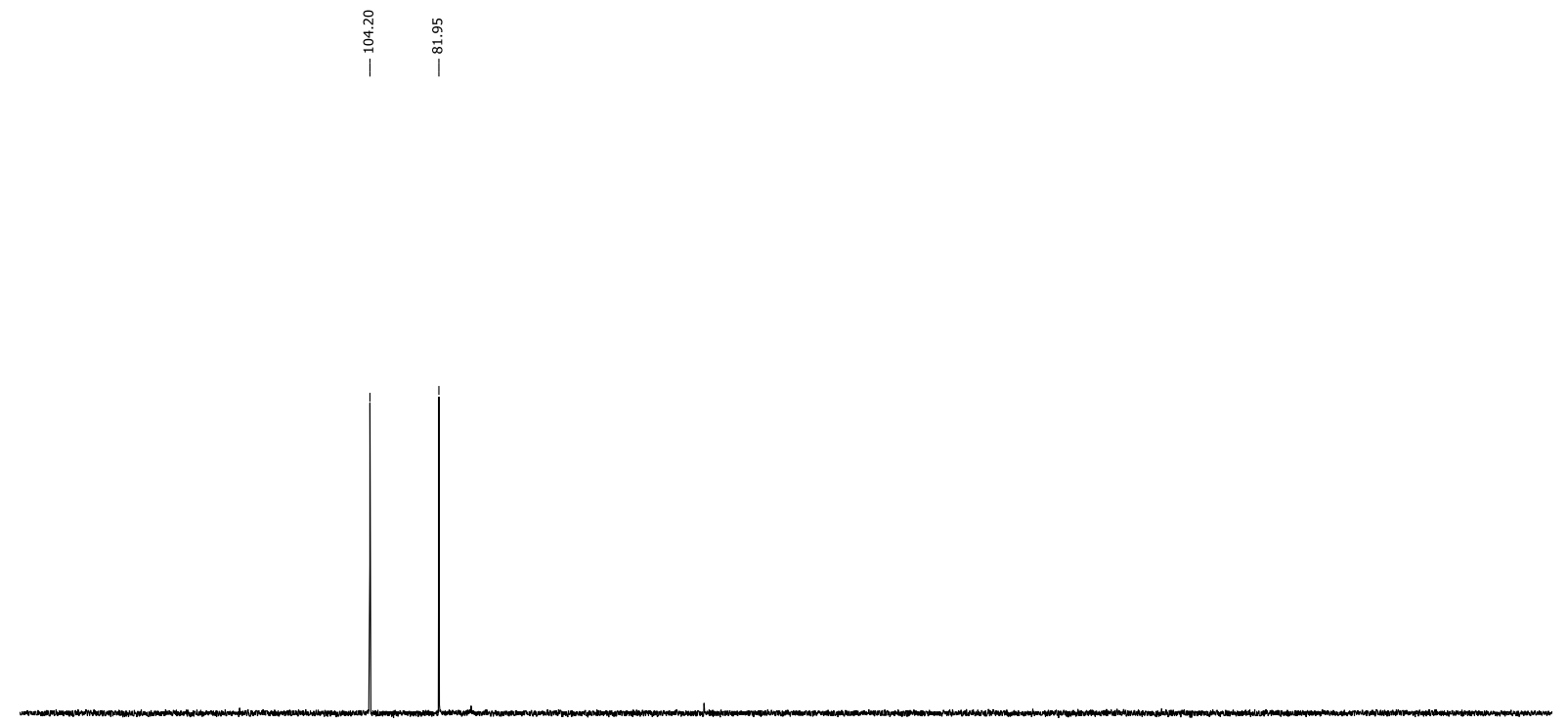

$\begin{array}{lllllllllllllllllllllllll}\mid & 180 & 160 & 140 & 120 & 100 & 80 & 60 & 40 & 20 & 0 & -20 & -40 & -60 & -80 & -100 & -120 & -140 & -160 & -180 & -200 & -220 & -240 & -260 & \mid\end{array}$

Figure S1B. ${ }^{31} \mathrm{P}\left\{{ }^{1} \mathrm{H}\right\}$ NMR $\left(202 \mathrm{MHz}, \mathrm{C}_{6} \mathrm{D}_{6}, 25^{\circ} \mathrm{C}\right)$ spectrum of (PNP)Fe(s-cis $\left.\mathrm{C}_{4} \mathrm{H}_{6}\right)$. 


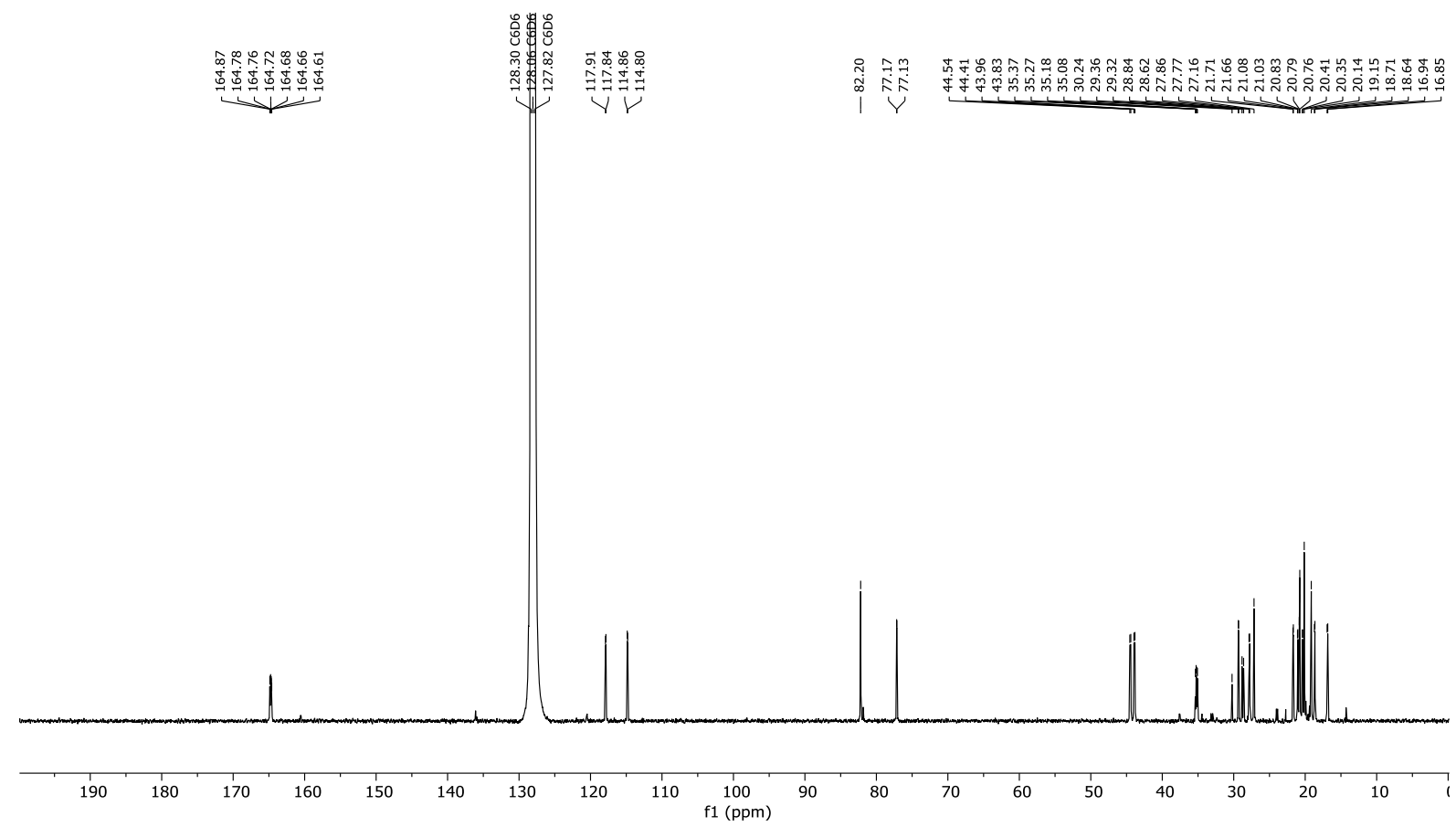

Figure S1C. ${ }^{13} \mathrm{C}\left\{{ }^{1} \mathrm{H}\right\}$ NMR $\left(101 \mathrm{MHz}, \mathrm{C}_{6} \mathrm{D}_{6}, 25^{\circ} \mathrm{C}\right)$ spectrum of (PNP)Fe(s-cis $\left.\mathrm{C}_{4} \mathrm{H}_{6}\right)$.

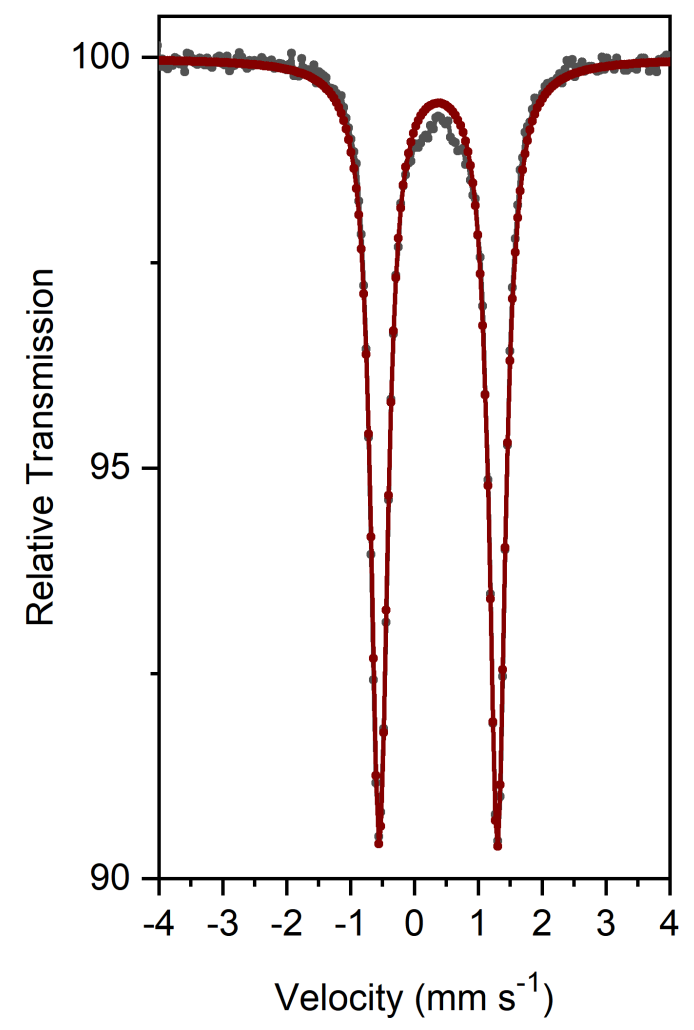

Figure S1D. Solid-state (80 K) Mössbauer spectrum of (PNP)Fe(s-cis $\left.\mathbf{C}_{4} \mathbf{H}_{6}\right)$. The experimental data (grey trace) was fit to the following parameters: $\delta=0.38 \mathrm{~mm} \mathrm{~s}^{-1},\left|\Delta \mathrm{E}_{\mathrm{Q}}\right|=1.85 \mathrm{~mm} \mathrm{~s}^{-1}$. The fit is shown in red. 

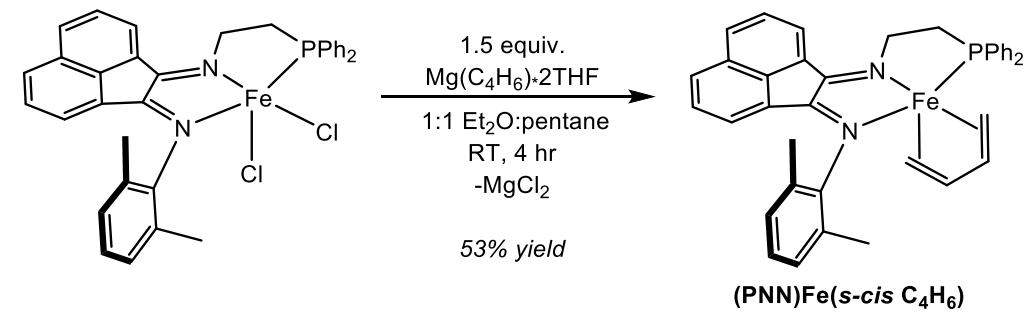

Preparation of (PNN)Fe(s-cis $\mathbf{C}_{4} \mathbf{H}_{6}$ ). To a $20 \mathrm{~mL}$ scintillation vial containing a stir bar in the glove box was added $0.200 \mathrm{~g}(0.360 \mathrm{mmol})$ of $(\mathrm{PNN}) \mathrm{FeCl}_{2}$ and $0.114 \mathrm{~g}(0.513 \mathrm{mmol}, 1.5$ equiv. $)$ of magnesium butadiene. $2 \mathrm{~mL}$ of pentane followed by $2 \mathrm{~mL}$ of $\mathrm{Et}_{2} \mathrm{O}$ were added to the vial resulting in an instantaneous color change to a deep magenta solution. The vial was sealed and the contents were stirred vigorously at room temperature in the glove box for 4 hours. The contents were then filtered through a pad of Celite after which the filtrate was evaporated to dryness. The deep magenta residue was taken up in minimal $(\sim 1 \mathrm{~mL})$ pentane and recrystallized at $-35{ }^{\circ} \mathrm{C}$ to yield $0.116 \mathrm{~g}(53 \%$ yield) of ( $\mathrm{PNN}) \mathrm{Fe}\left(\mathbf{s}-\mathrm{cis} \mathbf{C}_{4} \mathrm{H}_{6}\right)$ as a green, iridescent crystalline solid. Crystals suitable for X-ray diffraction were obtained from a concentrated diethyl ether solution at $-35{ }^{\circ} \mathrm{C}$. Anal Calc'd for $\mathrm{C}_{38} \mathrm{H}_{35} \mathrm{FeN}{ }_{2} \mathrm{P}$ : C, 75.25; $\mathrm{H}, 5.82 ; \mathrm{N}, 4.62$. Found: $\mathrm{C}, 74.80 ; \mathrm{H}, 5.99 ; \mathrm{N}, 4.21 .{ }^{1} \mathrm{H}$ NMR (400 MHz, $\left.\mathrm{C}_{6} \mathrm{D}_{6}, 25^{\circ} \mathrm{C}\right): \delta 7.49-7.42(\mathrm{~m}, 3 \mathrm{H}), 7.40(\mathrm{~d}, J=8.2 \mathrm{~Hz}, 1 \mathrm{H}), 7.36(\mathrm{~d}, J=6.9 \mathrm{~Hz}$, $1 \mathrm{H}), 7.29(\mathrm{~d}, J=8.2 \mathrm{~Hz}, 1 \mathrm{H}), 7.18(\mathrm{~s}, 2 \mathrm{H}), 7.14-7.07(\mathrm{~m}, 2 \mathrm{H}), 7.06-6.97(\mathrm{~m}, 5 \mathrm{H}), 6.83(\mathrm{dd}, J=$ 8.1, 7.1 Hz, 1H), $6.76-6.70(\mathrm{~m}, 1 \mathrm{H}), 6.67-6.60(\mathrm{~m}, 3 \mathrm{H}), 6.45(\mathrm{~d}, J=7.0 \mathrm{~Hz}, 1 \mathrm{H}), 6.37-6.25$ (m, 1H), $6.23-6.12(\mathrm{~m}, 1 \mathrm{H}), 4.07(\mathrm{ddt}, J=11.3,8.2,4.2 \mathrm{~Hz}, 1 \mathrm{H}), 3.85(\mathrm{ddt}, J=13.3,11.1,6.9$ $\mathrm{Hz}, 1 \mathrm{H}), 3.38$ (dtd, $J=15.1,8.2,2.6 \mathrm{~Hz}, 1 \mathrm{H}), 3.26$ (tdd, $J=14.1,11.2,2.6 \mathrm{~Hz}, 1 \mathrm{H}), 2.38(\mathrm{~s}, 2 \mathrm{H})$, $2.18(\mathrm{~s}, 2 \mathrm{H}), 2.15(\mathrm{~d}, J=7.7 \mathrm{~Hz}, 1 \mathrm{H}), 1.39(\mathrm{~d}, J=6.8 \mathrm{~Hz}, 2 \mathrm{H}),-2.84(\mathrm{dd}, J=18.7,8.2 \mathrm{~Hz}, 1 \mathrm{H}),-$ $3.05(\mathrm{t}, J=11.0 \mathrm{~Hz}, 1 \mathrm{H}) .$. The ${ }^{1} \mathrm{H}$ NMR spectrum is given in Figure S2A. ${ }^{31} \mathrm{P}\left\{{ }^{1} \mathrm{H}\right\} \mathrm{NMR}(202 \mathrm{MHz}$, $\left.\mathrm{C}_{6} \mathrm{D}_{6}, 25^{\circ} \mathrm{C}\right): \delta$ 70.4. The ${ }^{31} \mathrm{P}\left\{{ }^{1} \mathrm{H}\right\}$ NMR spectrum is given in Figure S2B. ${ }^{13} \mathrm{C}$ NMR $(126 \mathrm{MHz}$, $\left.\mathrm{C}_{6} \mathrm{D}_{6}\right) \delta 156.70,154.56,153.86,136.04,133.46,133.20,133.11,132.76,132.70,132.22,131.37$ $130.59,129.65,129.30,129.08,128.69,128.38,128.25,127.87,125.39,124.87,123.79,118.80$ $116.94,97.89,83.63,50.45,40.70,40.43,37.35,33.02,32.92,20.72,18.52,15.60$. The ${ }^{13} \mathrm{C}\left\{{ }^{1} \mathrm{H}\right\}$ 
NMR spectrum is given in Figure S1C. Solid-state Mössbauer $(80 \mathrm{~K}): \delta=0.33 \mathrm{~mm} \mathrm{~s}^{-1},\left|\Delta \mathrm{E}_{\mathrm{Q}}\right|=$ $1.50 \mathrm{~mm} \mathrm{~s}^{-1}$. The Mössbauer spectrum is given in Figure S2D.

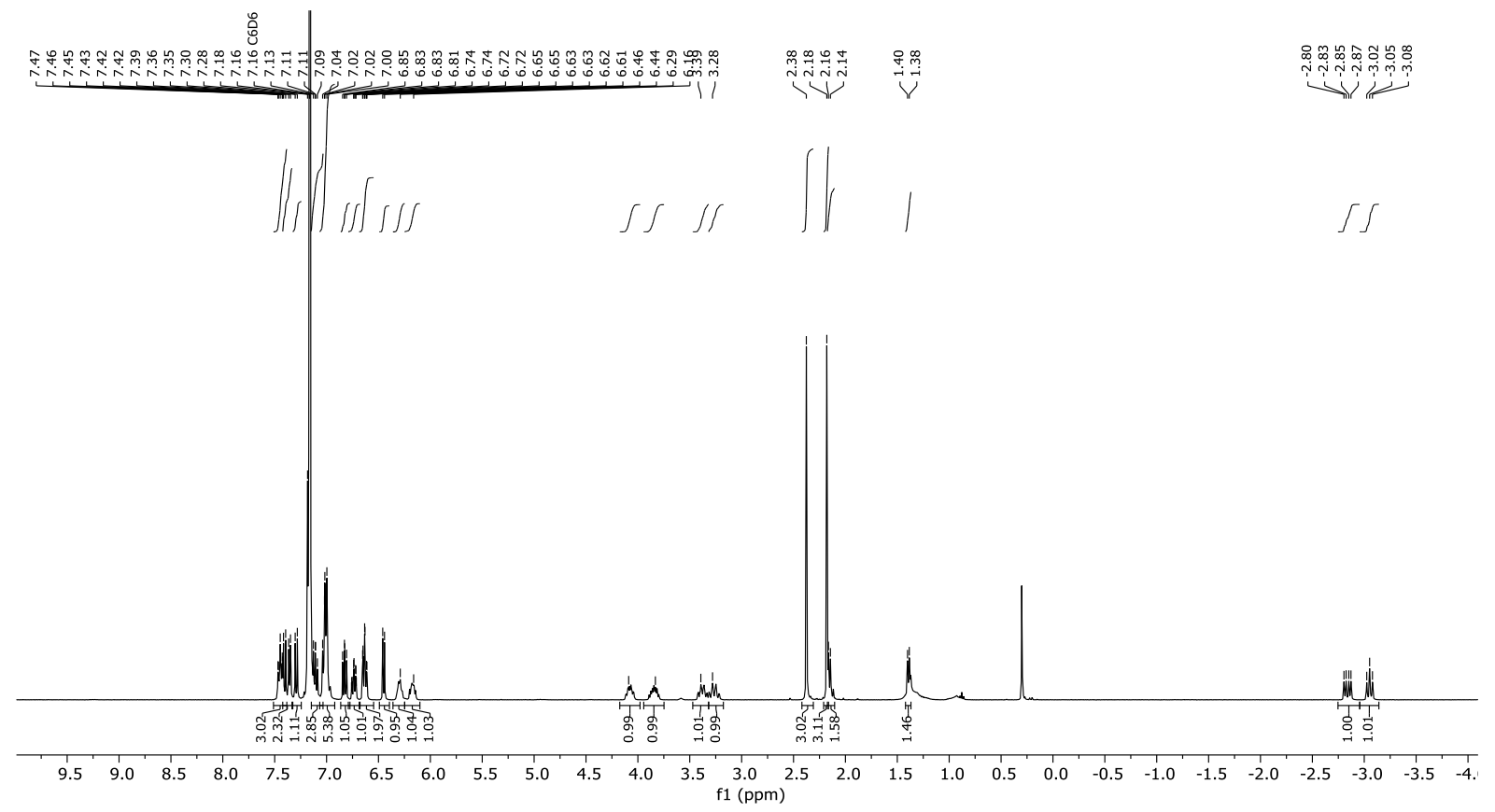

Figure S2A. ${ }^{1} \mathrm{H}$ NMR $\left(400 \mathrm{MHz}, \mathrm{C}_{6} \mathrm{D}_{6}, 25^{\circ} \mathrm{C}\right)$ spectrum of (PNN)Fe(s-cis $\left.\mathbf{C}_{4} \mathrm{H}_{6}\right)$.

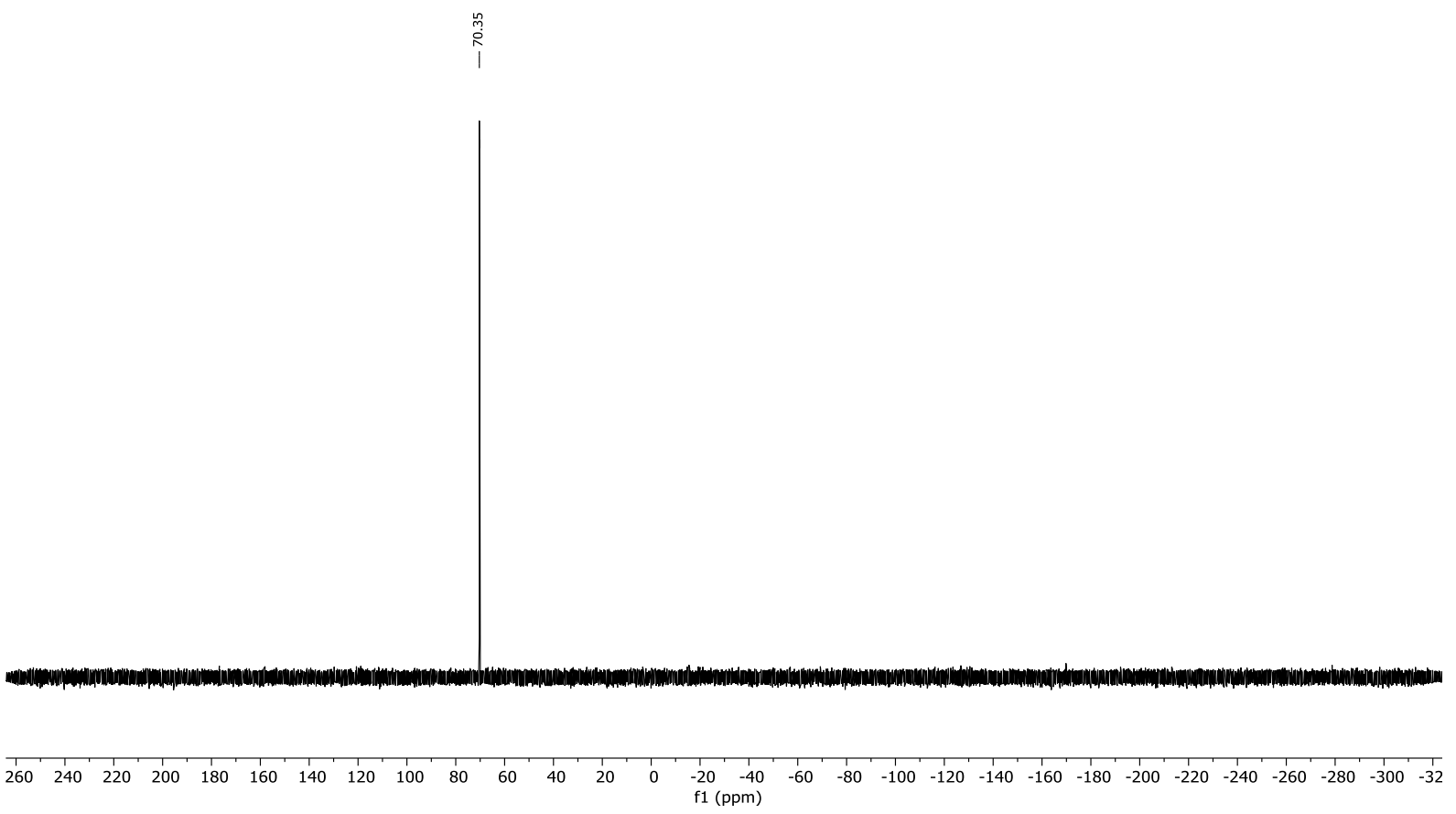

Figure S2B. ${ }^{31} \mathrm{P}\left\{{ }^{1} \mathrm{H}\right\} \mathrm{NMR}\left(202 \mathrm{MHz}, \mathrm{C}_{6} \mathrm{D}_{6}, 25^{\circ} \mathrm{C}\right)$ spectrum of (PNN)Fe(s-cis $\left.\mathrm{C}_{4} \mathrm{H}_{6}\right)$. 


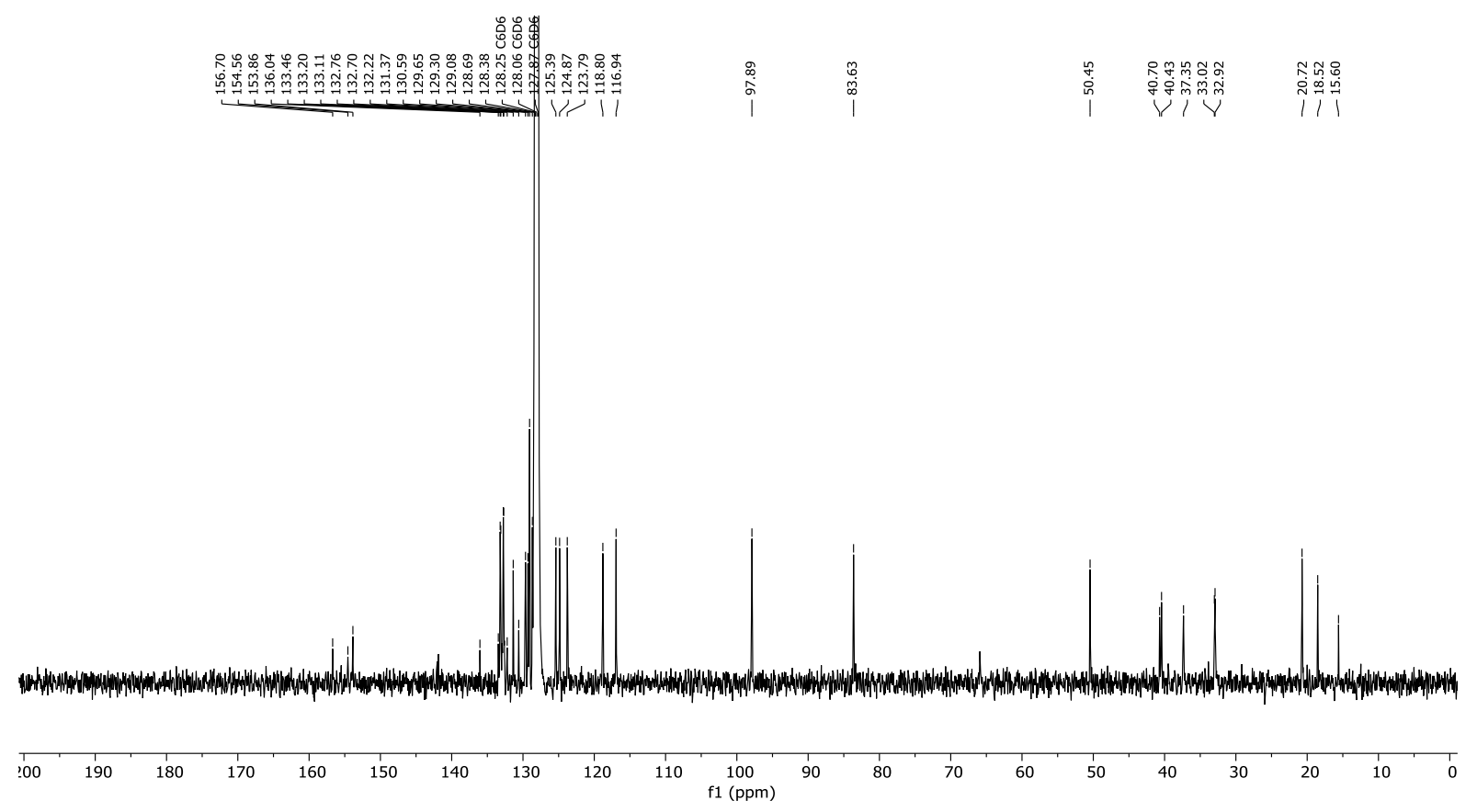

Figure S2C. ${ }^{13} \mathrm{C}\left\{{ }^{1} \mathrm{H}\right\} \mathrm{NMR}\left(101 \mathrm{MHz}, \mathrm{C}_{6} \mathrm{D}_{6}, 25^{\circ} \mathrm{C}\right)$ spectrum of (PNN)Fe(s-cis $\left.\mathrm{C}_{4} \mathrm{H}_{6}\right)$.

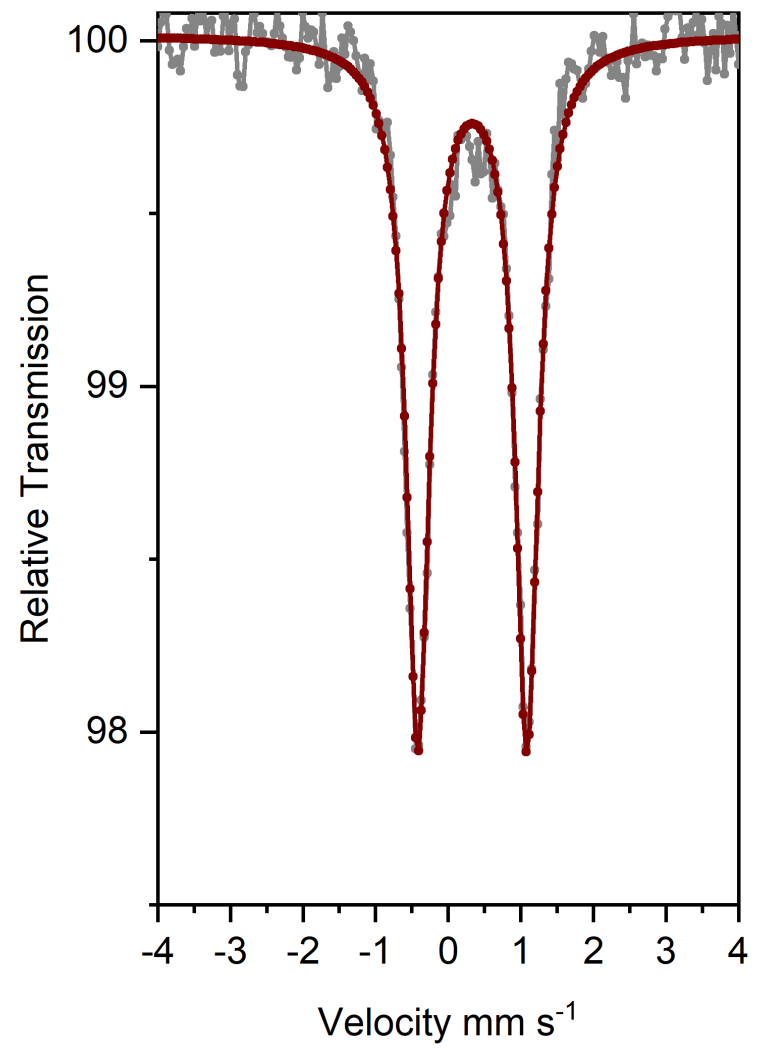

Figure S2D. Solid-state (80 K) Mössbauer spectrum of (PNN)Fe(s-cis $\left.\mathbf{C}_{4} \mathbf{H}_{6}\right)$. The experimental data (grey trace) was fit to the following parameters: $\delta=0.33 \mathrm{~mm} \mathrm{~s}^{-1},\left|\Delta \mathrm{E}_{Q}\right|=1.50 \mathrm{~mm} \mathrm{~s}^{-1}$. The fit is shown in red. 

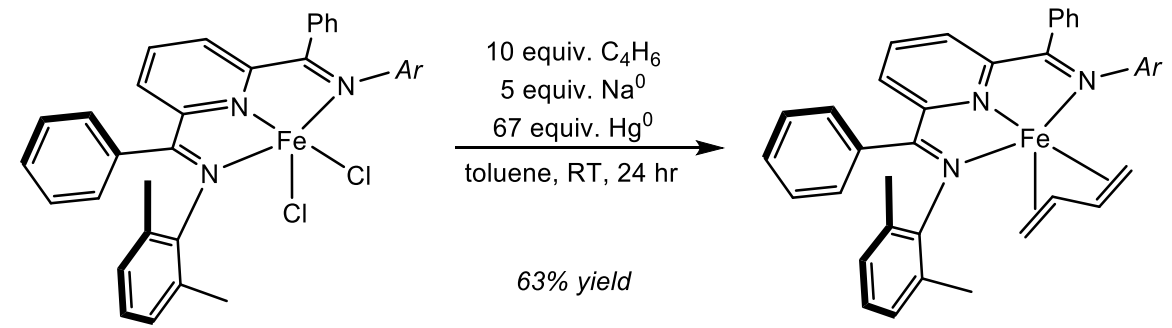

Preparation of ( $\left.{ }^{\mathrm{Me}(\mathrm{Ph})} \mathrm{PDI}\right) \mathrm{Fe}\left(\mathrm{s}\right.$-trans $\left.\mathrm{C}_{4} \mathrm{H}_{6}\right)$. To a $50 \mathrm{~mL}$ Schlenk bomb containing a stir bar in the glove box was added $10.8 \mathrm{~g}$ (54.0 mmol, 67 equiv.) of mercury and $\sim 4 \mathrm{~mL}$ of toluene. $0.054 \mathrm{~g}$ (2.33 mmol, 2.9 equiv.) of finely divided sodium metal were added to the flask after which the contents were stirred vigorously for 10 minutes. $0.500 \mathrm{~g}(0.806 \mathrm{mmol})$ of $\left({ }^{\mathrm{Me}(\mathrm{Ph})} \mathrm{PDI}\right) \mathrm{FeCl}_{2}$ was added to the solution and the flask was sealed and the contents frozen in liquid nitrogen. Butadiene ( $8.06 \mathrm{mmol}, 10$ equiv.) was added to the flask by calibrated gas bulb after which the flask and contents were thawed to room temperature and stirred vigorously for 24 hours. The deep red solution was decanted away from the amalgam in a glove box and filtered through a pad of Celite, after which the solvent was removed under vacuum. The deep red residue was taken up in minimal $(\sim 3 \mathrm{~mL})$ diethyl ether and recrystallized at $-35{ }^{\circ} \mathrm{C}$ to yield $0.312 \mathrm{~g}$ (63\% yield) of ( $\left.{ }^{\mathrm{Me}(\mathrm{Ph})} \mathrm{PDI}\right) \mathrm{Fe}\left(\mathrm{s}\right.$-trans $\mathrm{C}_{4} \mathrm{H}_{6}$ ) as a deep red crystalline solid. Crystals suitable for $\mathrm{X}$-ray diffraction were obtained from a concentrated toluene solution layered with pentane (1:2 toluene:pentane) at $-35{ }^{\circ} \mathrm{C}$. Anal Calc'd for $\mathrm{C}_{39} \mathrm{H}_{37} \mathrm{FeN}_{3}$ : C, 77.61; $\mathrm{H}, 6.18 ; \mathrm{N}, 6.96$. Found: $\mathrm{C}, 77.44 ; \mathrm{H}, 5.80 ; \mathrm{N}$, 6.58. ${ }^{1} \mathrm{H}$ NMR $\left(400 \mathrm{MHz}, \mathrm{C}_{6} \mathrm{D}_{6}, 25^{\circ} \mathrm{C}\right): \delta 8.18(\mathrm{~d}, J=7.7 \mathrm{~Hz}, 2 \mathrm{H}), 7.32(\mathrm{t}, J=7.7 \mathrm{~Hz}, 1 \mathrm{H}), 7.14-$ $7.04(\mathrm{~m}, 4 \mathrm{H}), 7.02-6.87(\mathrm{~m}, 6 \mathrm{H}), 6.84-6.74(\mathrm{~m}, 2 \mathrm{H}), 6.68(\mathrm{~d}, \mathrm{~J}=7.5 \mathrm{~Hz}, 4 \mathrm{H}), 5.01-4.58(\mathrm{~m}$, 2H), $3.50(\mathrm{dd}, J=12.1,6.0 \mathrm{~Hz}, 2 \mathrm{H}), 2.87(\mathrm{~d}, J=6.2 \mathrm{~Hz}, 2 \mathrm{H}), 1.59(\mathrm{~s}, 12 \mathrm{H})$. The ${ }^{1} \mathrm{H}$ NMR spectrum is given in Figure S3A. ${ }^{13} \mathrm{C}\left\{{ }^{1} \mathrm{H}\right\} \mathrm{NMR}\left(101 \mathrm{MHz}, \mathrm{C}_{6} \mathrm{D}_{6}\right) \delta 154.55,152.70,150.01,138.57,137.39$, 130.77, 129.02, 127.53, 127.04, 125.24, 123.96, 120.31, 119.28, 103.91, 86.80, 70.19, 67.02, $24.59,21.67,21.09,20.94,15.59,1.42$. The ${ }^{13} \mathrm{C}\left\{{ }^{1} \mathrm{H}\right\}$ NMR spectrum is given in Figure S3B. Solidstate Mössbauer $(80 \mathrm{~K}): \delta=0.40 \mathrm{~mm} \mathrm{~s}^{-1},\left|\Delta \mathrm{E}_{\mathrm{Q}}\right|=0.77 \mathrm{~mm} \mathrm{~s}^{-1}$. The Mössbauer spectrum is reported in Figure S3C. 


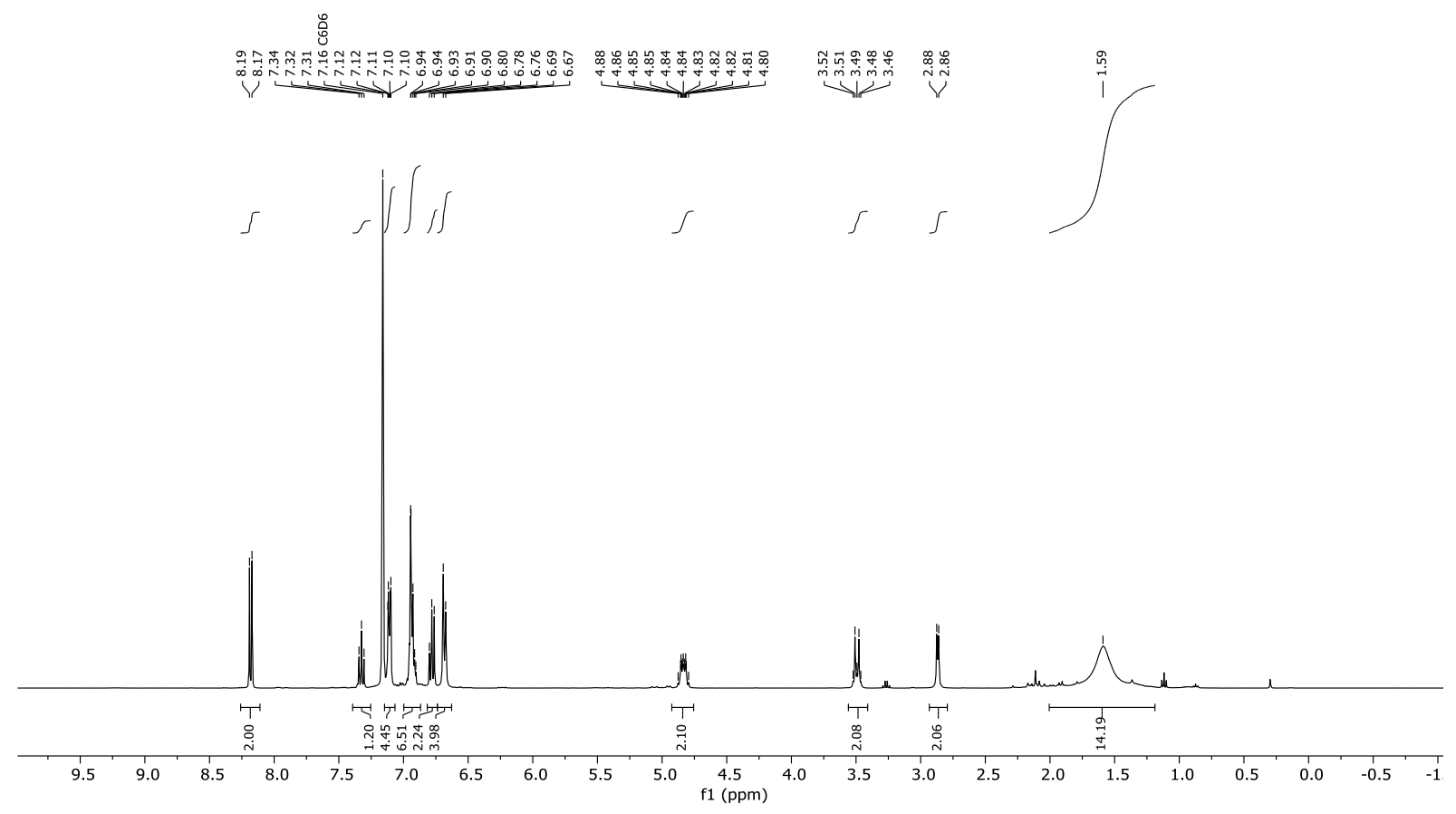

Figure S3A. ${ }^{1} \mathrm{H}$ NMR $\left(400 \mathrm{MHz}, \mathrm{C}_{6} \mathrm{D}_{6}, 25^{\circ} \mathrm{C}\right)$ spectrum of ( $\left.{ }^{\mathrm{Me}(\mathrm{Ph})} \mathrm{PDI}\right) \mathrm{Fe}\left(\mathbf{s}-\right.$ trans $\left.\mathrm{C}_{4} \mathrm{H}_{6}\right)$.

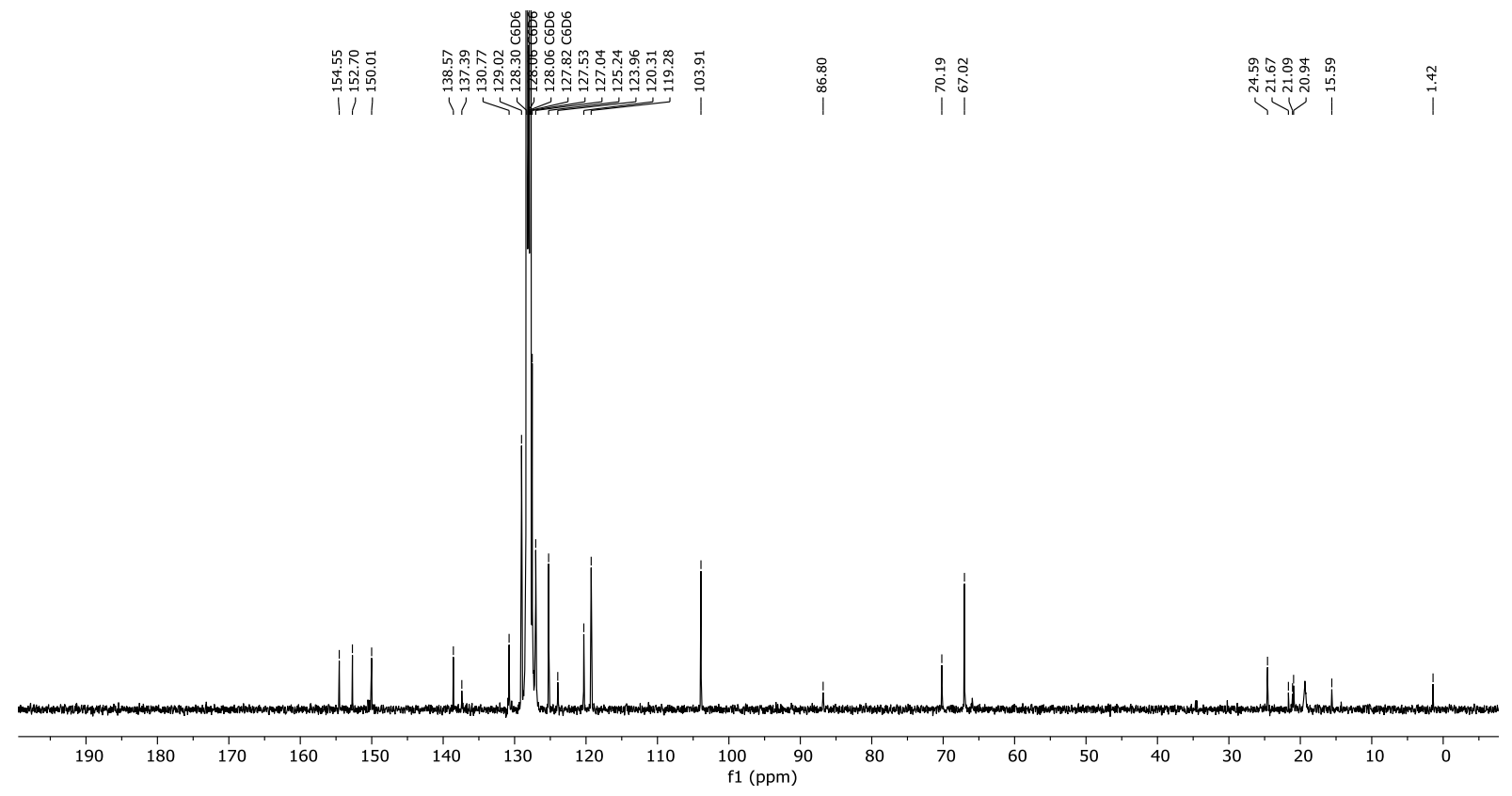

Figure S3B. ${ }^{13} \mathrm{C}\left\{{ }^{1} \mathrm{H}\right\}$ NMR $\left(101 \mathrm{MHz}, \mathrm{C}_{6} \mathrm{D}_{6}, 25^{\circ} \mathrm{C}\right)$ spectrum of (Me(Ph)PDI)Fe(s-trans $\left.\mathrm{C}_{4} \mathrm{H}_{6}\right)$. 


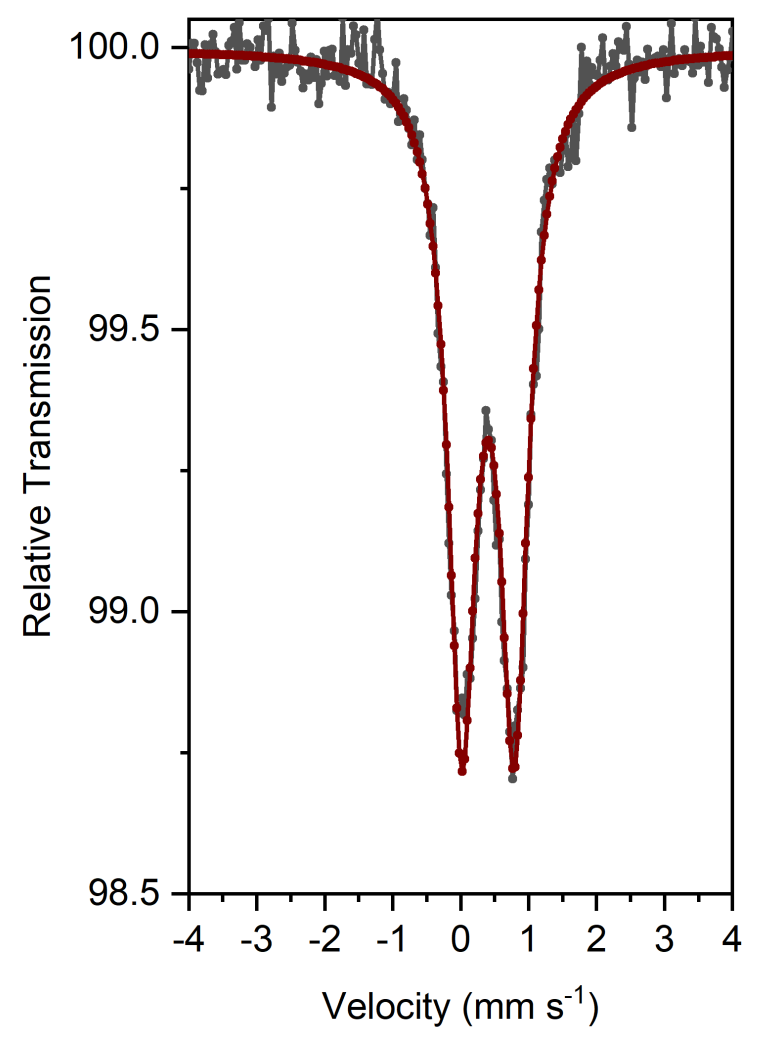

Figure S3C. Solid-state ( $80 \mathrm{~K}$ ) Mössbauer spectrum of of (Me(Ph)PDI)Fe(s-trans $\mathrm{C}_{4} \mathrm{H}_{6}$ ). The experimental data (grey trace) was fit to the following parameters: $\delta=0.40 \mathrm{~mm} \mathrm{~s}^{-1},\left|\Delta \mathrm{E}_{\mathrm{Q}}\right|=0.77 \mathrm{~mm} \mathrm{~s}^{-1}$. The fit is shown in red. 

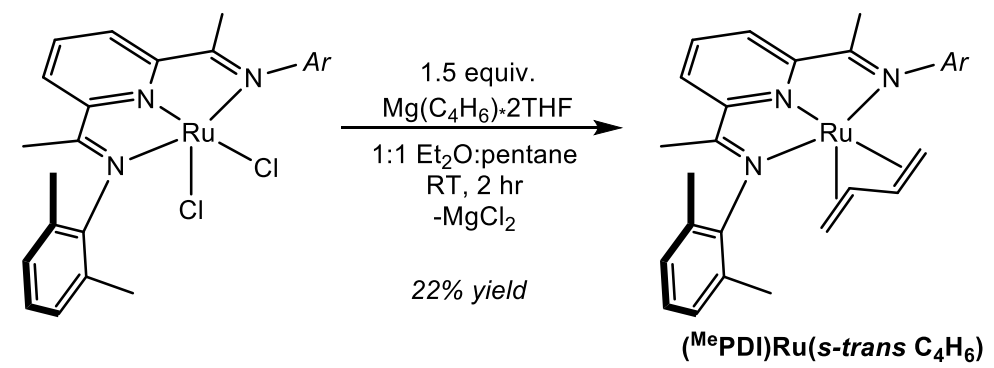

Preparation of ( $\left.{ }^{\mathrm{Me}} \mathrm{PDI}\right) \mathrm{Ru}\left(\mathrm{s}\right.$-trans $\mathrm{C}_{4} \mathrm{H}_{6}$ ). To a $20 \mathrm{~mL}$ scintillation vial containing a stir bar in the glove box was added $0.108 \mathrm{~g}(0.199 \mathrm{mmol})$ of ( $\left.{ }^{\mathrm{Me} P D I}\right) \mathrm{RuCl}_{2}$ and $0.067 \mathrm{~g}(0.299 \mathrm{mmol}, 1.5$ equiv. $)$ of magnesium butadiene. $2 \mathrm{~mL}$ of pentane followed by $2 \mathrm{~mL}$ of $\mathrm{Et}_{2} \mathrm{O}$ was added to the vial. The vial was sealed and the contents were stirred vigorously at room temperature in the glove box for 2 hours resulting in a deep green solution. The contents were then filtered through a pad of Celite, after which the filtrate was evaporated to dryness and triturated with $\sim 1 \mathrm{~mL}$ pentane to afford $0.022 \mathrm{~g}(22 \%$ yield $)$ of $\left({ }^{\mathrm{Me}} \mathrm{PDI}\right) \mathrm{Ru}\left(\mathrm{s}\right.$-trans $\left.\mathrm{C}_{4} \mathrm{H}_{6}\right)$ as a deep green solid. Anal Calc'd for $\mathrm{C}_{29} \mathrm{H}_{33} \mathrm{RuN}_{3}$ : C, 66.39; $\mathrm{H}, 6.34 ; \mathrm{N}, 8.01$. Found: $\mathrm{C}, 66.06 ; \mathrm{H}, 6.29 ; \mathrm{N}, 7.70 .{ }^{1} \mathrm{H}$ NMR $(400 \mathrm{MHz}$, $\mathrm{C}_{6} \mathrm{D}_{6}, 25^{\circ} \mathrm{C}$ ): $\delta 8.02(\mathrm{~d}, J=7.7 \mathrm{~Hz}, 2 \mathrm{H}$ ), 7.13 (obs t, $J=7.7 \mathrm{~Hz}, 1 \mathrm{H}), 6.91(\mathrm{~m}, 6 \mathrm{H}), 3.46-3.31$ (m, 2H), 2.91 (d, J = 5.3 Hz, 2H), 2.87 (dd, $J=10.3,5.0 \mathrm{~Hz}, 2 \mathrm{H}$ ), $2.23(\mathrm{~s}, 6 \mathrm{H}), 1.65$ (s, 6H), 1.47 $(\mathrm{s}, 6 \mathrm{H})$. The ${ }^{1} \mathrm{H}$ NMR spectrum is given in Figure $\mathrm{S} 4 \mathrm{~A} .{ }^{13} \mathrm{C}\left\{{ }^{1} \mathrm{H}\right\} \mathrm{NMR}\left(101 \mathrm{MHz}, \mathrm{C}_{6} \mathrm{D}_{6}\right) \delta 156.27$, 153.32, 153.24, 151.42, 150.38, 149.28, 149.21, 148.98, 148.93, 148.89, 146.41, 145.43, 145.33, 144.99, 144.54, 144.17, 131.67, 131.59, 130.50, 130.32, 130.19, 130.09, 130.04, 129.87, 129.35, $128.73,128.69,128.60,125.41,125.33,125.23,125.19,122.71,121.18,120.65,120.42,119.55$, 119.32, 113.40, 113.11, 111.67, 92.63, 92.27, 91.71, 90.31, 66.15, 66.10, 65.93, 56.93, 56.36, $54.23,54.19,54.12,46.61,30.24,19.12,18.90,18.85,18.81,18.41,18.05,17.98,17.63,17.55$, $17.53,16.65,16.62,16.55,15.61,15.26,14.40 .$. The ${ }^{13} \mathrm{C}\left\{{ }^{1} \mathrm{H}\right\}$ NMR spectrum is given in Figure S4B. 


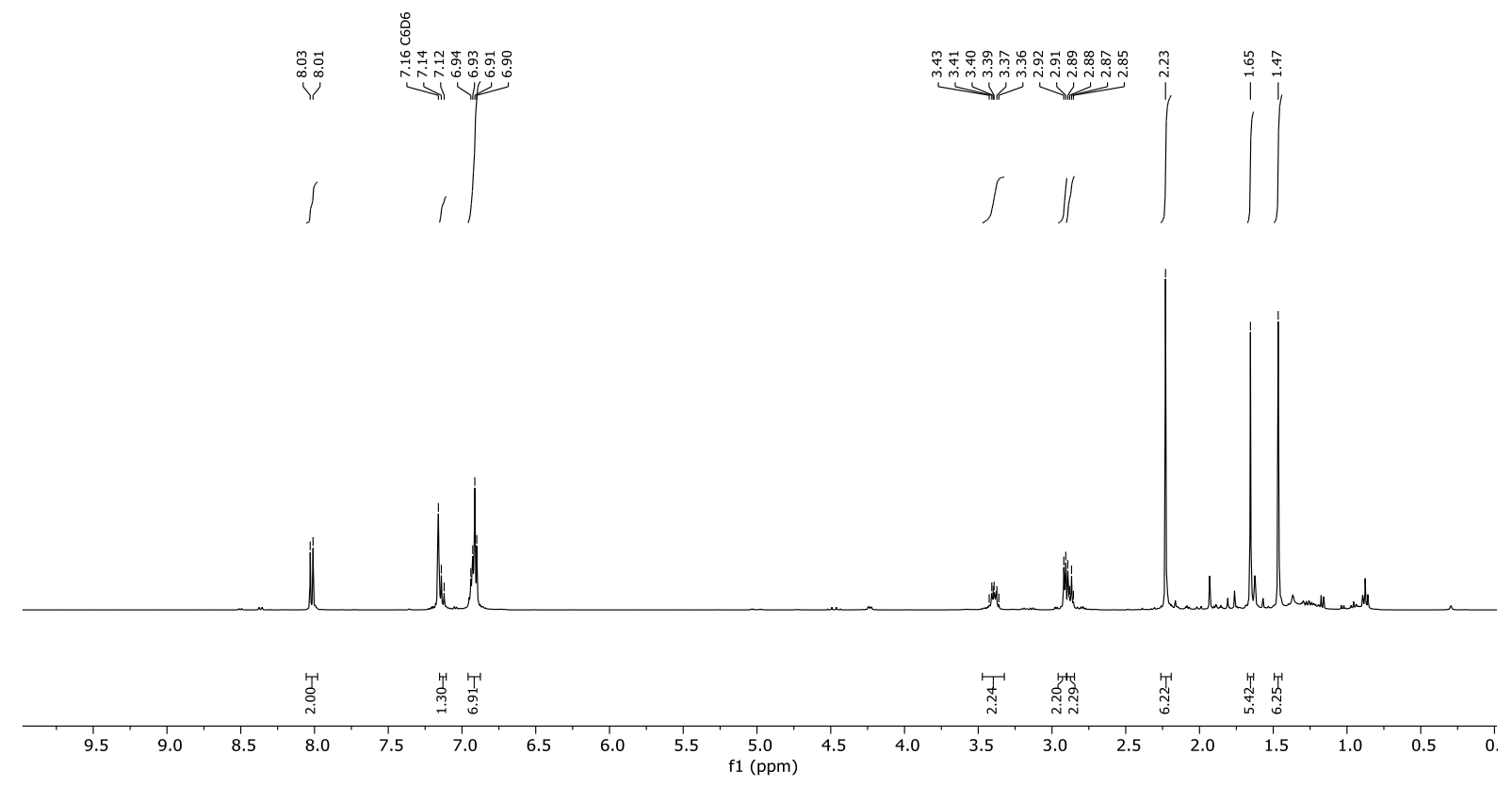

Figure S4A. ${ }^{1} \mathrm{H}$ NMR $\left(400 \mathrm{MHz}, \mathrm{C}_{6} \mathrm{D}_{6}, 25^{\circ} \mathrm{C}\right)$ spectrum of (MepDI)Ru(s-trans $\mathrm{C}_{4} \mathrm{H}_{6}$ ).

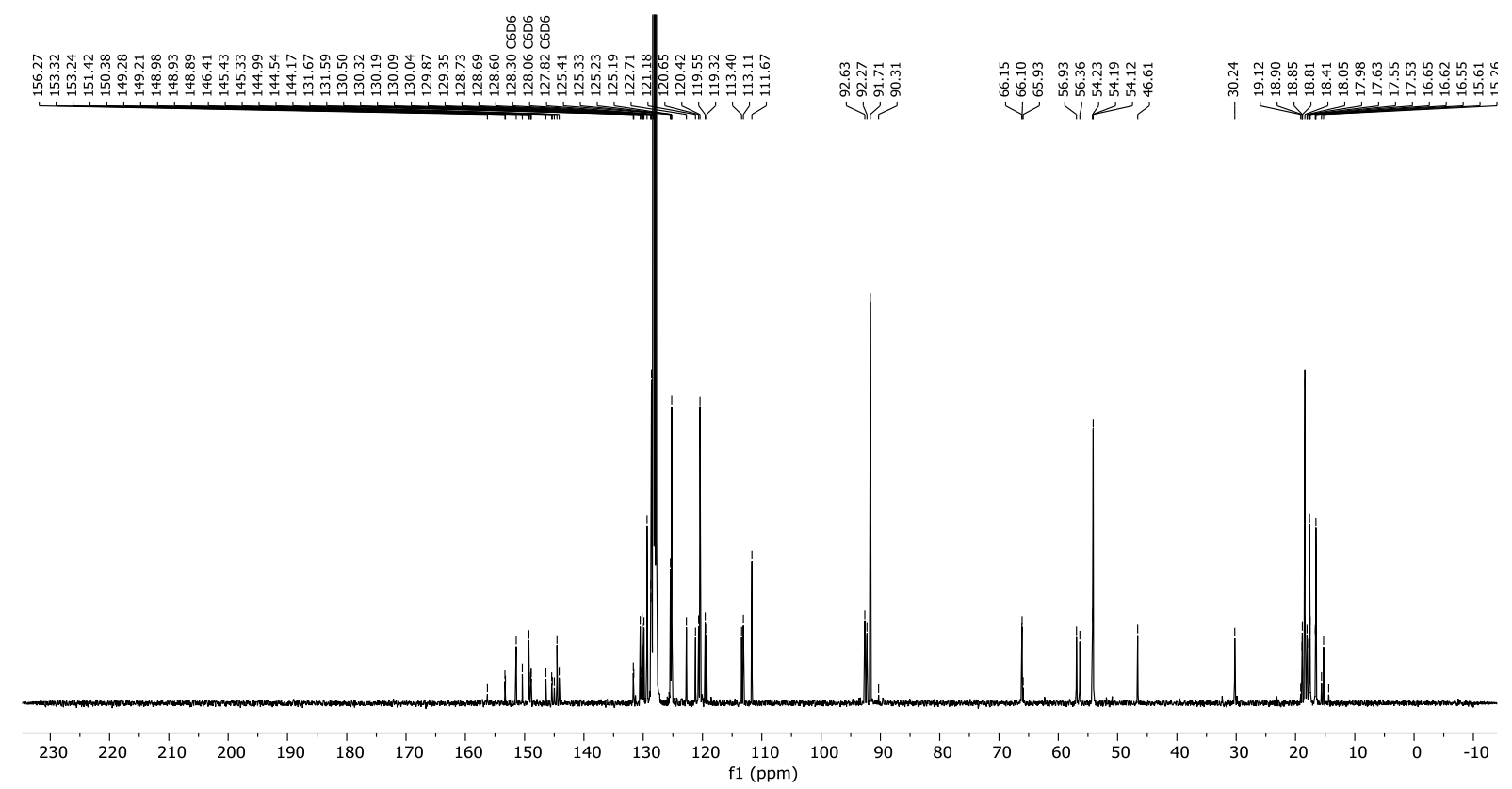

Figure S4B. ${ }^{13} \mathrm{C}\left\{{ }^{1} \mathrm{H}\right\} \mathrm{NMR}\left(101 \mathrm{MHz}, \mathrm{C}_{6} \mathrm{D}_{6}, 25^{\circ} \mathrm{C}\right)$ spectrum of (MePDI)Ru(s-trans $\mathrm{C}_{4} \mathrm{H}_{6}$ ). 


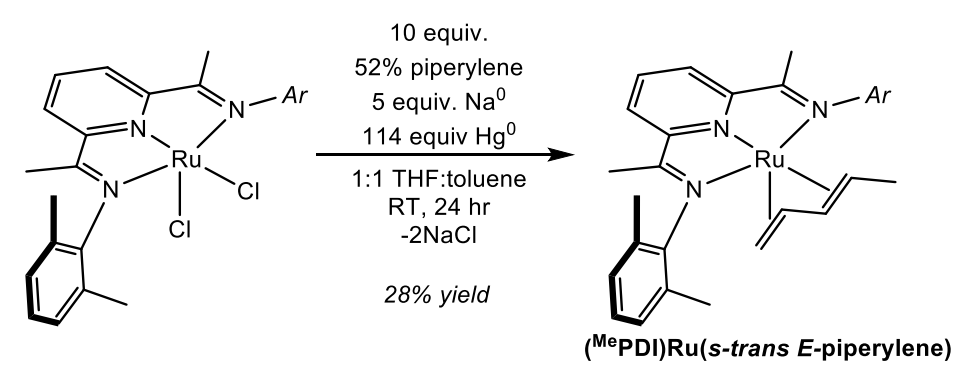

Preparation of ( $\left.{ }^{\mathrm{Pe}} \mathrm{PDI}\right) \mathrm{Fe}(\mathrm{s}$-trans E-piperylene). To a $20 \mathrm{~mL}$ scintillation vial containing a stir bar in the glove box were added $8.460 \mathrm{~g}(42.18 \mathrm{mmol}, 114$ equiv.) of mercury and $\sim 2 \mathrm{~mL}$ of toluene. $0.042 \mathrm{~g}(1.846 \mathrm{mmol}, 5$ equiv.) of finely divided sodium metal was added to the flask, after which the contents were stirred vigorously for 10 minutes. A solution of $0.200 \mathrm{~g}(0.370 \mathrm{mmol})$ of ( $\left.{ }^{\mathrm{Me} P D I}\right) \mathrm{RuCl}_{2}$ and $0.485 \mathrm{~g}$ of $52 \%$ s-trans E-piperylene mixture (3.70 mmol s-trans E-piperylene, 10 equiv.) in $\sim 2 \mathrm{~mL}$ of THF was prepared and added to the scintillation vial after which the vial was sealed and stirred at room temperature for 24 hours. The deep green solution was decanted away from the amalgam in a glove box and evaporated to dryness under vacuum. The deep green residue was extracted with pentane $(\sim 10 \mathrm{~mL})$ and the filtrate passed through a pad of Celite. The pentane was removed under vacuum, and the green residue was dissolved in minimal toluene $(\sim 1 \mathrm{~mL})$ and layered with $\sim 2 \mathrm{~mL}$ pentane. The product was recrystallized at $-35^{\circ} \mathrm{C}$ to yield 0.056 g (28\% yield) of (MePDI)Ru(s-trans E-piperylene) as a deep green crystalline solid. Crystals suitable for X-ray diffraction were obtained from the recrystallization conditions above. Anal Calc'd for $\mathrm{C}_{30} \mathrm{H}_{35} \mathrm{RuN}_{3}$ : C, 66.89; $\mathrm{H}, 6.55 ; \mathrm{N}, 7.80$. Found: C, 67.01; H, 6.29; N, 7.70. ${ }^{1} \mathrm{H}$ NMR (500 MHz, $\left.\mathrm{C}_{6} \mathrm{D}_{6}, 25^{\circ} \mathrm{C}\right): 8.04(\mathrm{~d}, J=7.7 \mathrm{~Hz}, 1 \mathrm{H}), 7.99(\mathrm{~d}, J=7.6 \mathrm{~Hz}, 1 \mathrm{H}), 7.12(\mathrm{t}, J=7.7 \mathrm{~Hz}, 1 \mathrm{H}), 7.03-$ $6.83(\mathrm{~m}, 6 \mathrm{H}), 3.73(\mathrm{dd}, J=10.3,7.2 \mathrm{~Hz}, 1 \mathrm{H}), 3.62(\mathrm{dq}, J=12.8,6.4 \mathrm{~Hz}, 1 \mathrm{H}), 3.24(\mathrm{dt}, J=11.2$, $6.5 \mathrm{~Hz}, 1 \mathrm{H}), 3.01(\mathrm{~d}, J=11.0 \mathrm{~Hz}, 1 \mathrm{H}), 2.48(\mathrm{~d}, J=5.9 \mathrm{~Hz}, 1 \mathrm{H}), 2.22(\mathrm{~d}, J=9.6 \mathrm{~Hz}, 6 \mathrm{H}), 1.76(\mathrm{~d}$, $J=3.0 \mathrm{~Hz}, 6 \mathrm{H}), 1.45(\mathrm{~s}, 6 \mathrm{H}), 0.98(\mathrm{~d}, J=6.4 \mathrm{~Hz}, 3 \mathrm{H})$. The ${ }^{1} \mathrm{H}$ NMR spectrum is given in Figure S5A. ${ }^{13} \mathrm{C}$ NMR $\left(101 \mathrm{MHz}, \mathrm{C}_{6} \mathrm{D}_{6}\right) \delta 151.52,151.43,149.86,149.18,145.32,144.42,130.94$, $130.53,129.96,128.63,128.30,127.82,125.08,120.80,120.19,112.11,91.95,85.70,72.53$, 
$51.24,30.24,19.32,18.67,18.53,17.72,16.70,16.50,16.36$. The ${ }^{13} \mathrm{C}\left\{{ }^{1} \mathrm{H}\right\}$ NMR spectrum is given in Figure S5B.

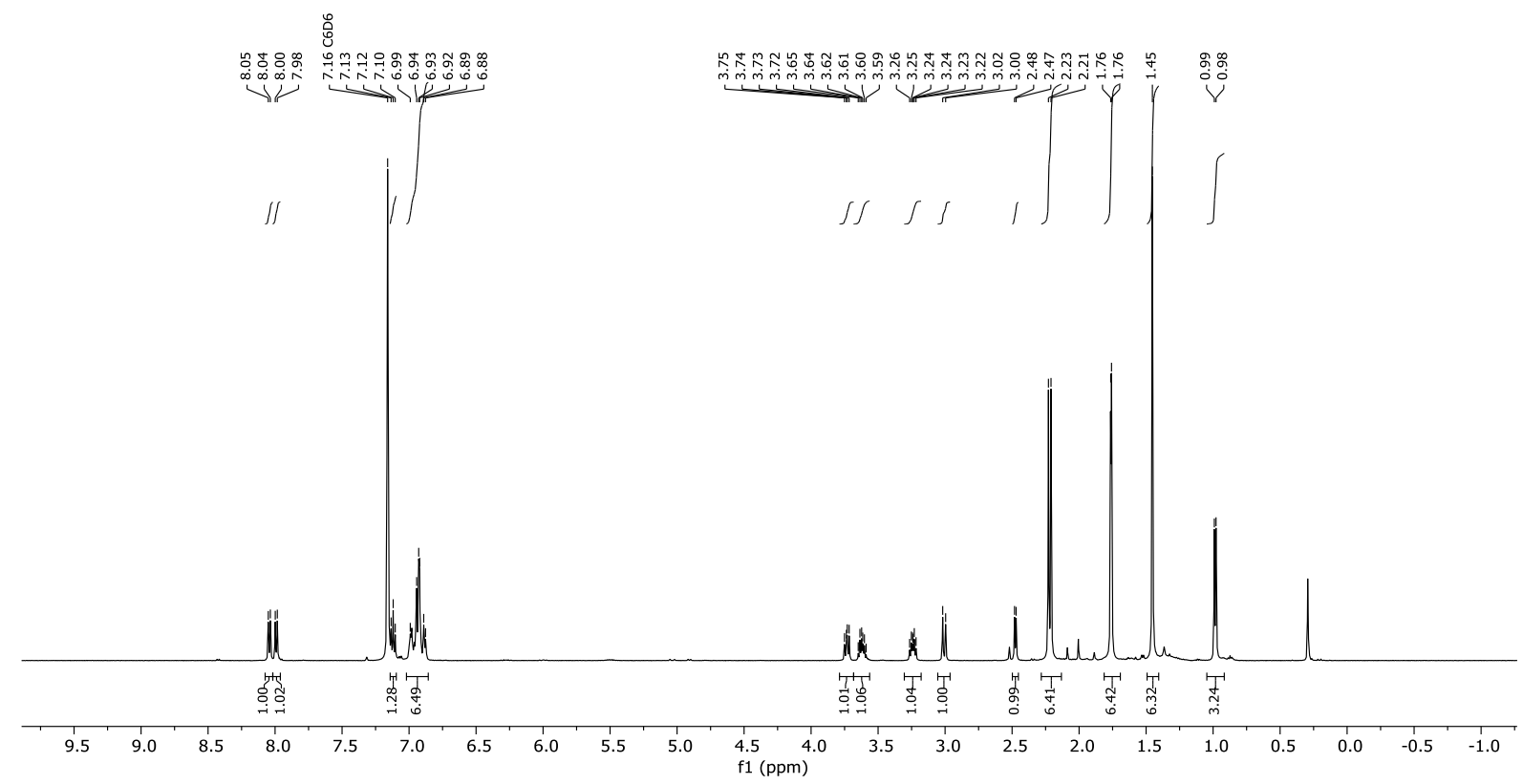

Figure S5A. ${ }^{1} \mathrm{H}$ NMR (500 MHz, $\left.\mathrm{C}_{6} \mathrm{D}_{6}, 25^{\circ} \mathrm{C}\right)$ spectrum of (MePDI)Ru(s-trans E-piperylene).

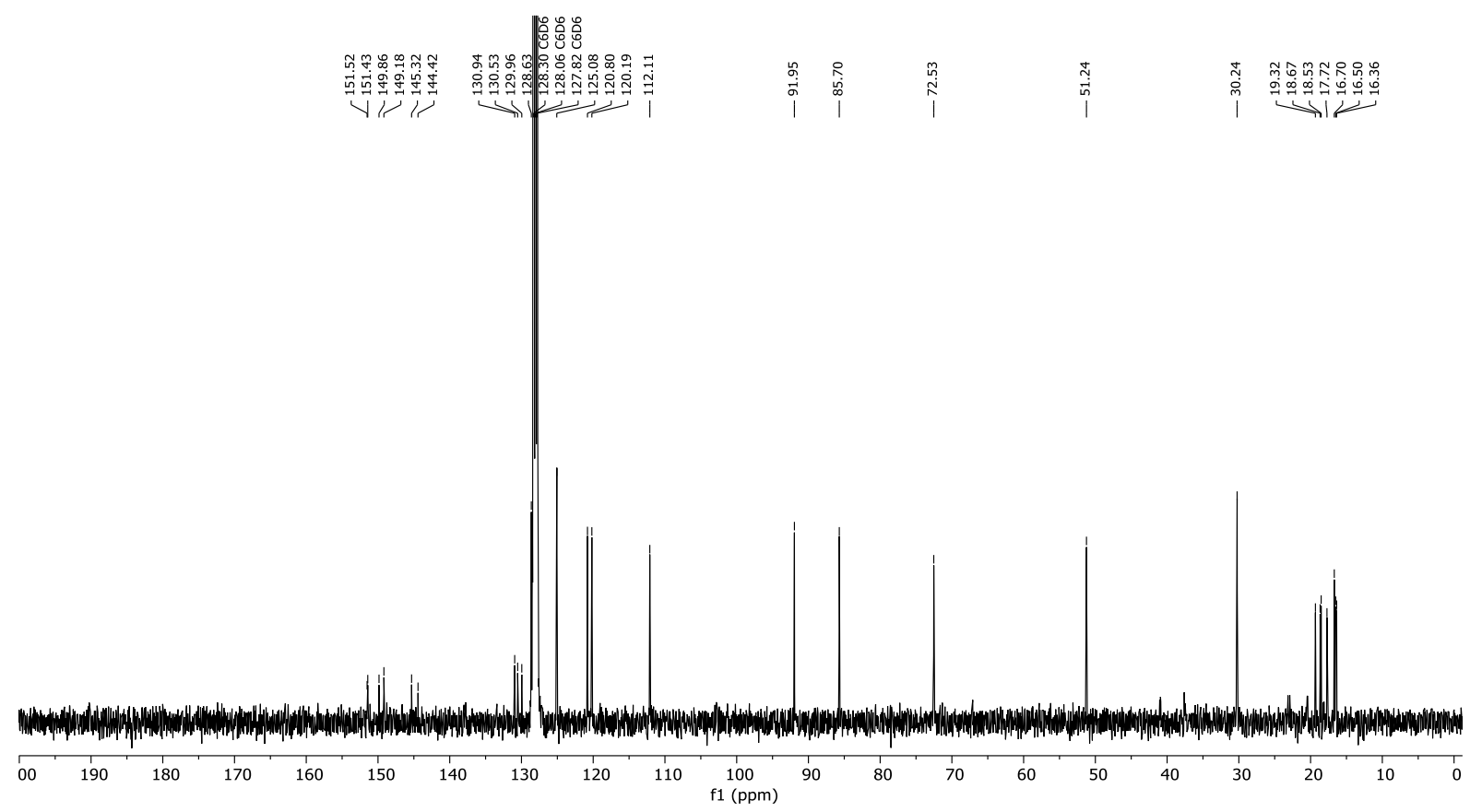

Figure S5B. ${ }^{13} \mathrm{C}\left\{{ }^{1} \mathrm{H}\right\}$ NMR $\left(101 \mathrm{MHz}, \mathrm{C}_{6} \mathrm{D}_{6}, 25^{\circ} \mathrm{C}\right)$ spectrum of (MePDI)Ru(s-trans E-piperylene). 


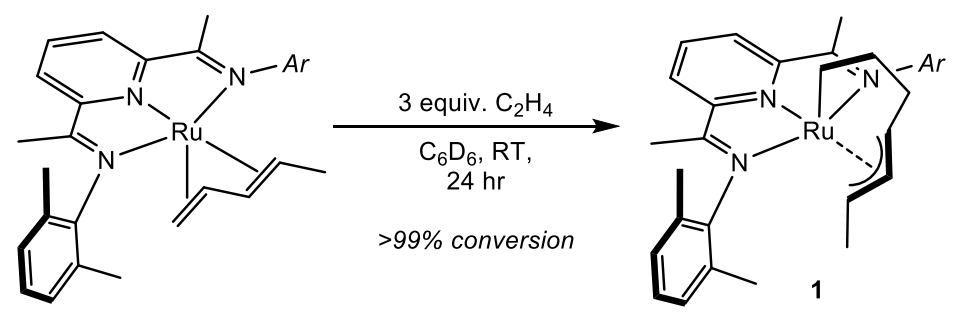

NMR-Scale Synthesis and Identification of 1. To a J. Young tube in the glove box was added a solution of $0.008 \mathrm{~g}(0.0142 \mathrm{mmol})$ of (MePDI)Ru(s-trans E-piperylene) in $0.600 \mathrm{~mL}$ of $\mathrm{C}_{6} \mathrm{D}_{6}$. The tube was sealed and frozen in liquid nitrogen after which $0.0427 \mathrm{mmol}$ (3 equiv.) of ethylene were added using a calibrated gas bulb. The contents of the tube were thawed in a room temperature water bath and mixed by inversion for 24 hours to afford 1 as a green-yellow solution. Excess ethylene was removed by vacuum transfer of the volatiles. The residue was reconstituted with $0.600 \mathrm{~mL}$ of $\mathrm{C}_{6} \mathrm{D}_{6}$ in the glovebox to afford spectroscopically pure 1 in quantitative NMR yield. The structure of 1 was assigned by two-dimensional NMR spectroscopy. ${ }^{1} \mathrm{H} N M R\left(400 \mathrm{MHz}, \mathrm{C}_{6} \mathrm{D}_{6}\right)$ $\delta 8.01(\mathrm{dd}, J=7.7,0.8 \mathrm{~Hz}, 1 \mathrm{H}), 7.86(\mathrm{dd}, J=7.8,0.9 \mathrm{~Hz}, 1 \mathrm{H}), 7.06(\mathrm{t}, J=7.8 \mathrm{~Hz}, 2 \mathrm{H}), 7.00(\mathrm{~d}, J$ $=7.5 \mathrm{~Hz}, 1 \mathrm{H}), 6.95(\mathrm{~d}, J=6.6 \mathrm{~Hz}, 1 \mathrm{H}), 6.88(\mathrm{~d}, J=7.3 \mathrm{~Hz}, 1 \mathrm{H}), 5.15(\mathrm{t}, J=9.8 \mathrm{~Hz}, 1 \mathrm{H}), 4.68(\mathrm{td}$, $J=9.6,4.7 \mathrm{~Hz}, 1 \mathrm{H}), 2.75-2.65(\mathrm{~m}, 1 \mathrm{H}), 2.60(\mathrm{tdd}, J=12.1,7.3,4.3 \mathrm{~Hz}, 2 \mathrm{H}), 2.43-2.31(\mathrm{~m}$, 1H), $2.19(\mathrm{~s}, 3 \mathrm{H}), 2.13(\mathrm{~s}, 3 \mathrm{H}), 2.11(\mathrm{~s}, 3 \mathrm{H}), 2.10(\mathrm{~s}, 3 \mathrm{H}), 1.44(\mathrm{~s}, 3 \mathrm{H}), 1.37(\mathrm{~d}, J=6.5 \mathrm{~Hz}, 3 \mathrm{H})$, $1.30(\mathrm{~s}, 3 \mathrm{H}),-0.59(\mathrm{ddd}, J=9.6,7.6,1.8 \mathrm{~Hz}, 1 \mathrm{H}),-0.92(\mathrm{q}, J=9.1 \mathrm{~Hz}, 1 \mathrm{H})$. The ${ }^{1} \mathrm{H}$ NMR spectrum is given in Figure S6A. ${ }^{13} \mathrm{C}$ NMR $\left(101 \mathrm{MHz}, \mathrm{C}_{6} \mathrm{D}_{6}\right) \delta 128.42,127.92,127.68,127.44,125.06$, $124.98,119.87,119.16,114.10,110.95,91.40,69.31,43.57,43.24,38.75,19.00,18.43,18.25$, 17.82, 17.54, 16.89, 16.21. The ${ }^{13} \mathrm{C}\left\{{ }^{1} \mathrm{H}\right\}$ spectrum is reported in Figure S6B. The ${ }^{1} \mathrm{H}-{ }^{1} \mathrm{H}$ COSY, ${ }^{1} \mathrm{H}-{ }^{13} \mathrm{C}\left\{{ }^{1} \mathrm{H}\right\}-\mathrm{HSQC}$, and ${ }^{1} \mathrm{H}-{ }^{13} \mathrm{C}\left\{{ }^{1} \mathrm{H}\right\}-\mathrm{HMBC}$ spectra used to assign the structure of 1 are given in Figures S6C, S6D, and S6E, respectively. UV-Visible (pentane, $\left.25^{\circ} \mathrm{C}\right): 217 \mathrm{~nm}\left(\varepsilon=7001 \mathrm{M}^{-1} \mathrm{~cm}^{-}\right.$ $\left.{ }^{1}\right), 282 \mathrm{~nm}\left(\varepsilon=2331 \mathrm{M}^{-1} \mathrm{~cm}^{-1}\right), 469 \mathrm{~nm}\left(\varepsilon=1615 \mathrm{M}^{-1} \mathrm{~cm}^{-1}\right), 741 \mathrm{~nm}\left(\varepsilon=395 \mathrm{M}^{-1} \mathrm{~cm}^{-1}\right)$. The UVVisible spectrum is reported in Figure S6F. 


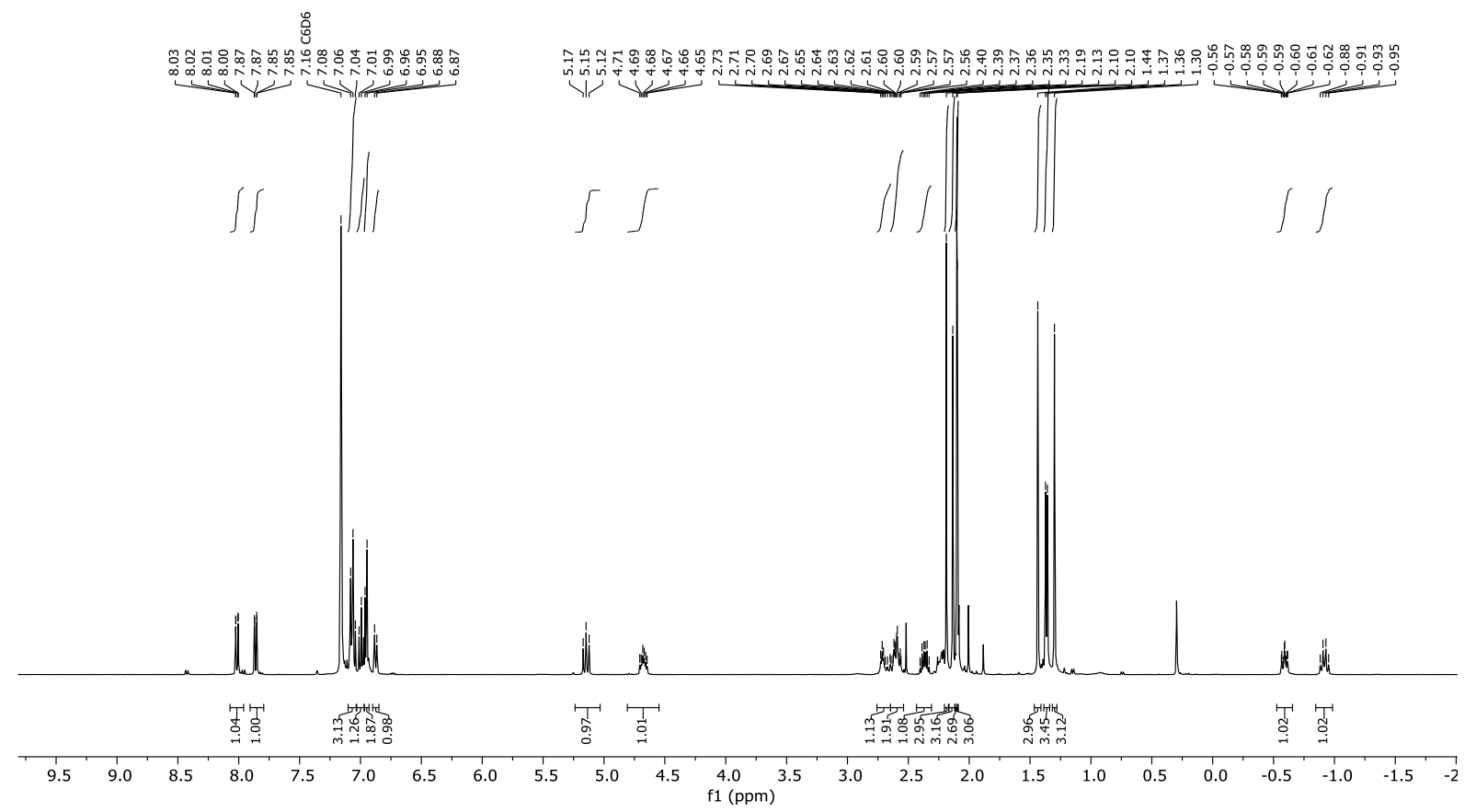

Figure S6A. ${ }^{1} \mathrm{H}$ NMR (400 MHz, $\left.\mathrm{C}_{6} \mathrm{D}_{6}, 25^{\circ} \mathrm{C}\right)$ spectrum of 1.

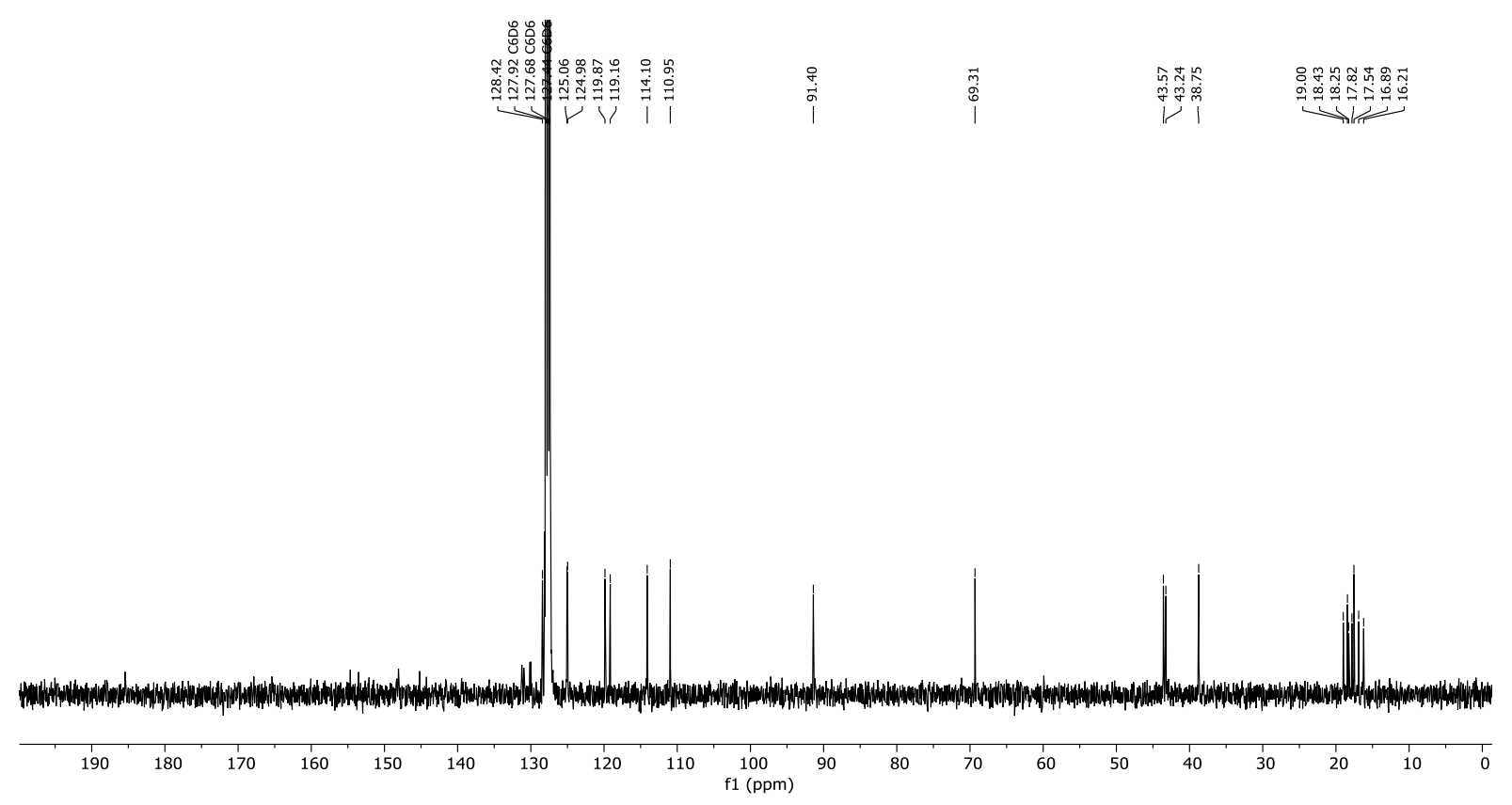

Figure S6B. ${ }^{13} \mathrm{C}\left\{{ }^{1} \mathrm{H}\right\}$ NMR $\left(101 \mathrm{MHz}, \mathrm{C}_{6} \mathrm{D}_{6}, 25^{\circ} \mathrm{C}\right)$ spectrum of 1. 


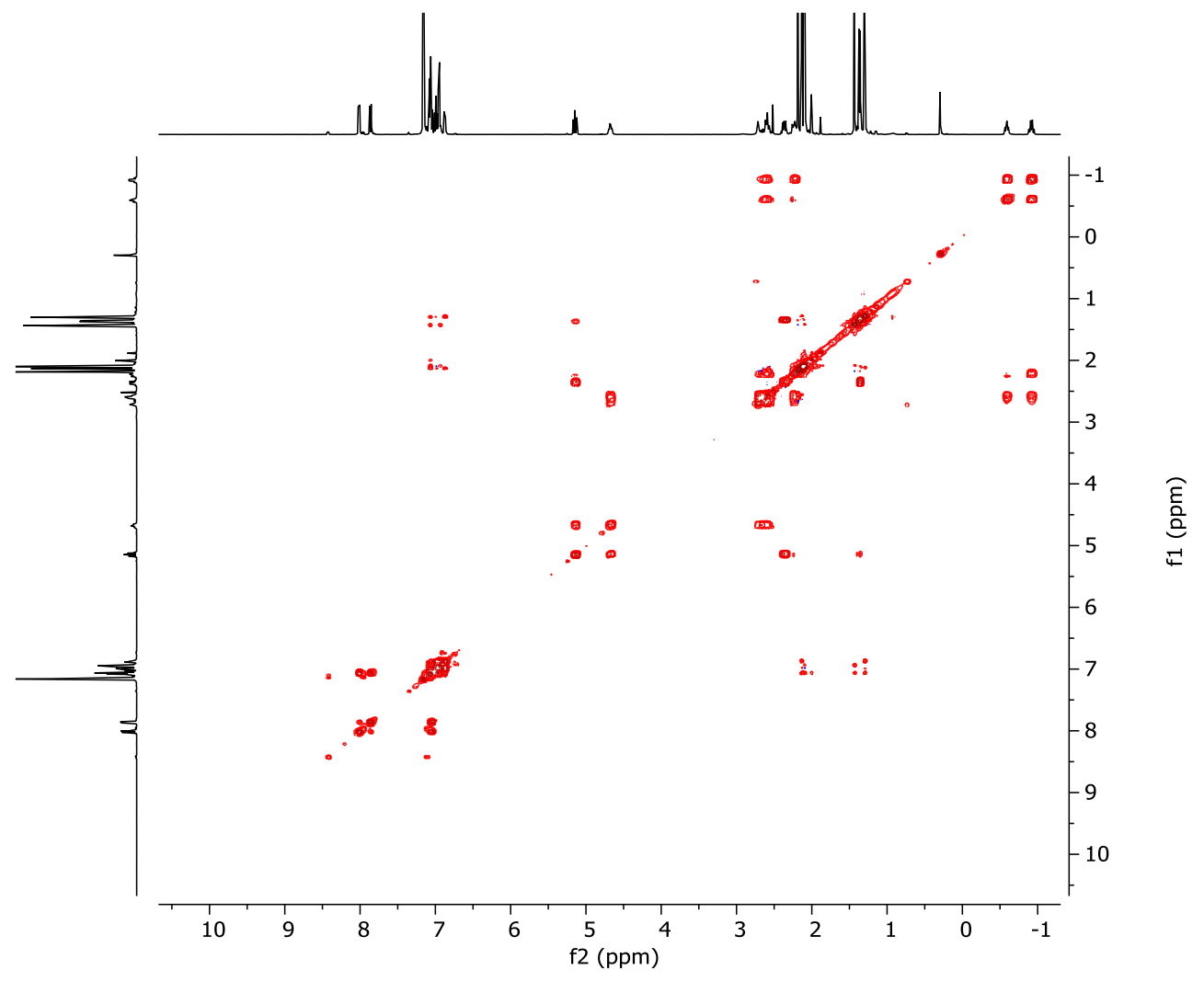

Figure S6C. ${ }^{1} \mathrm{H}-{ }^{-1} \mathrm{H}$ COSY NMR $\left(400 \mathrm{MHz}, \mathrm{C}_{6} \mathrm{D}_{6}, 25^{\circ} \mathrm{C}\right)$ spectrum of 1.

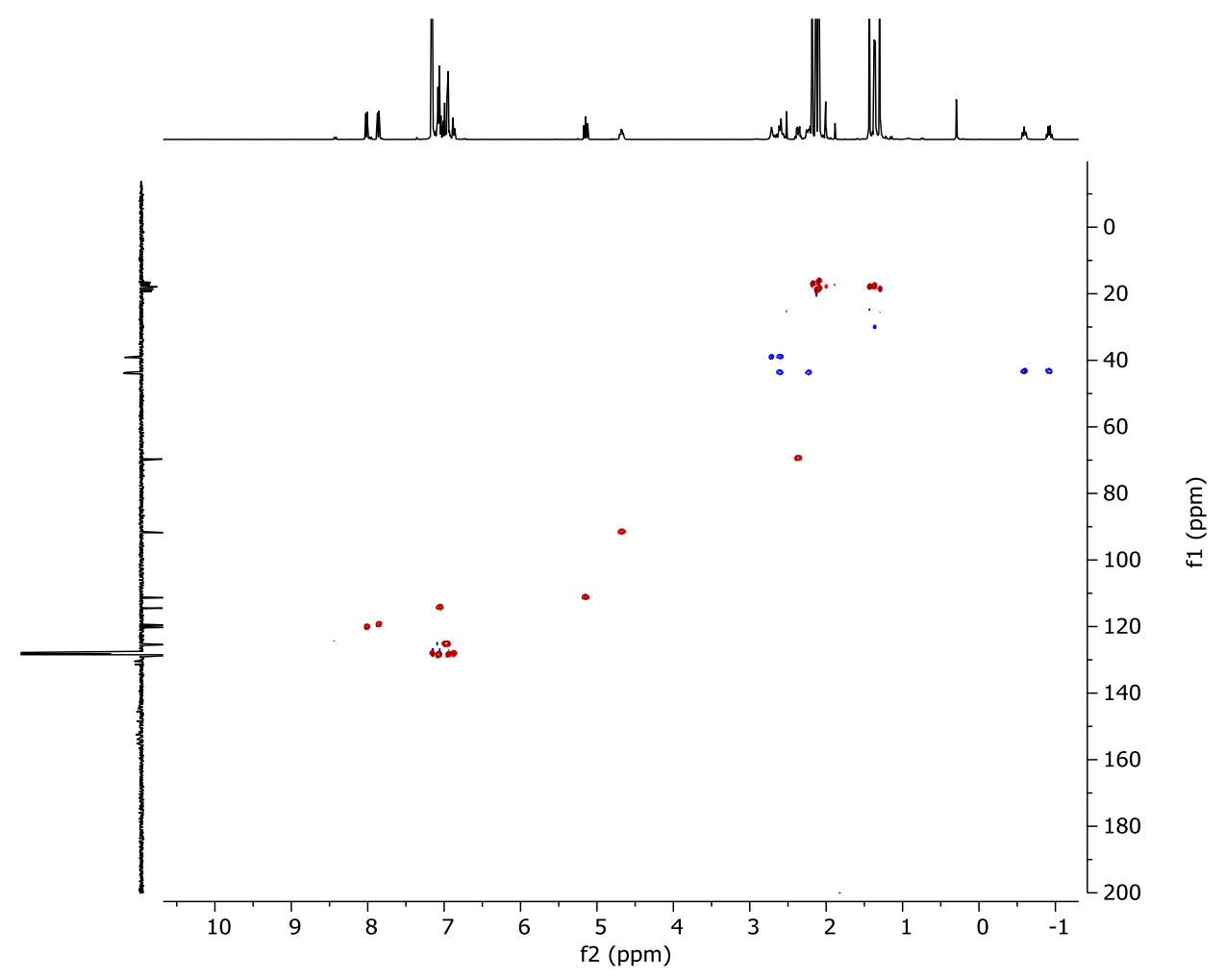

Figure S6D. ${ }^{1} \mathrm{H}-{ }^{13} \mathrm{C}\left\{{ }^{1} \mathrm{H}\right\} \mathrm{HSQC}$ NMR $\left(400 \mathrm{MHz}, 101 \mathrm{MHz}, \mathrm{C}_{6} \mathrm{D}_{6}, 25^{\circ} \mathrm{C}\right)$ spectrum of 1. 


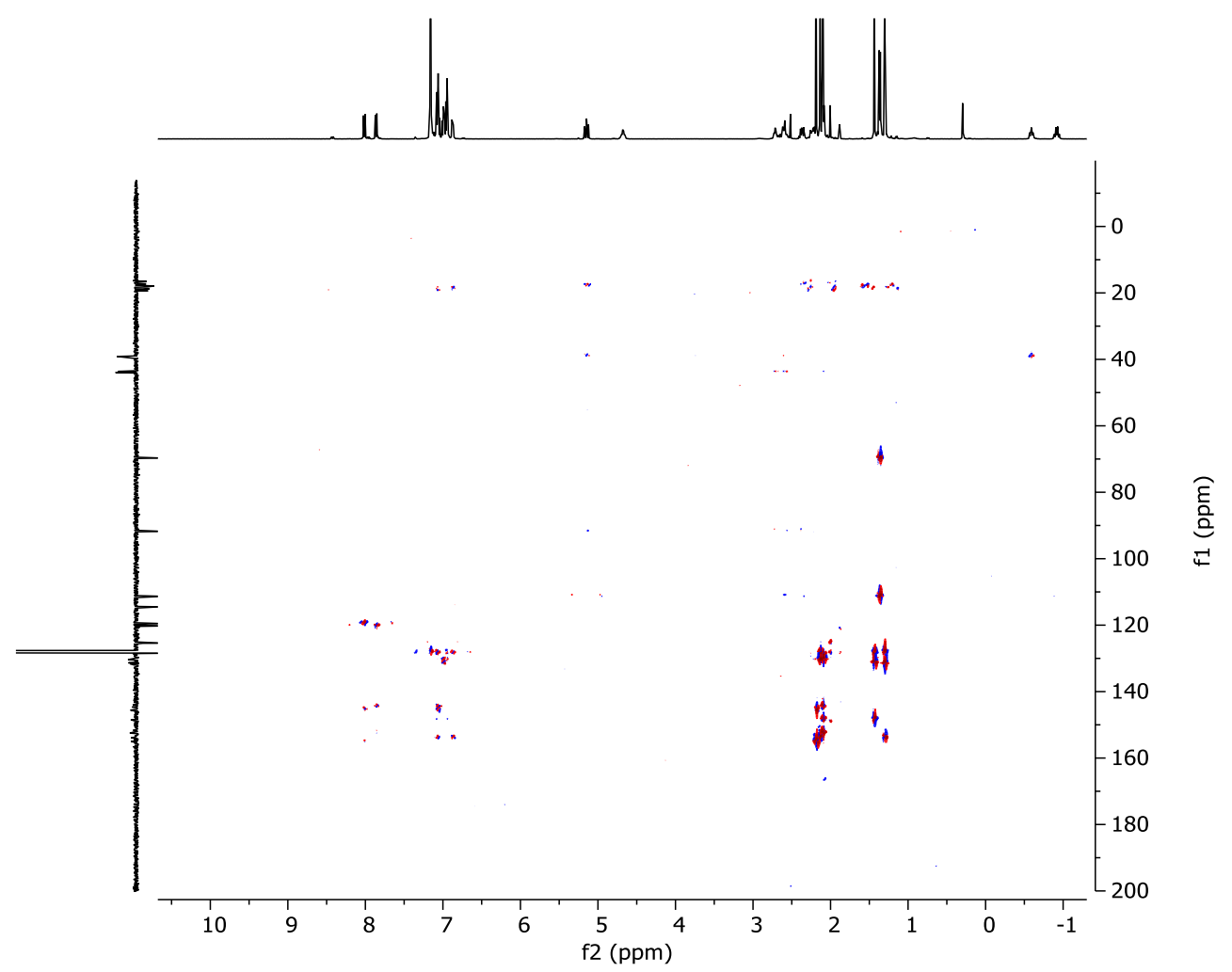

Figure S6E. ${ }^{1} \mathrm{H}-{ }^{13} \mathrm{C}\left\{{ }^{1} \mathrm{H}\right\}$ HMBC NMR $\left(400 \mathrm{MHz}, 101 \mathrm{MHz}, \mathrm{C}_{6} \mathrm{D}_{6}, 25^{\circ} \mathrm{C}\right)$ spectrum of 1.

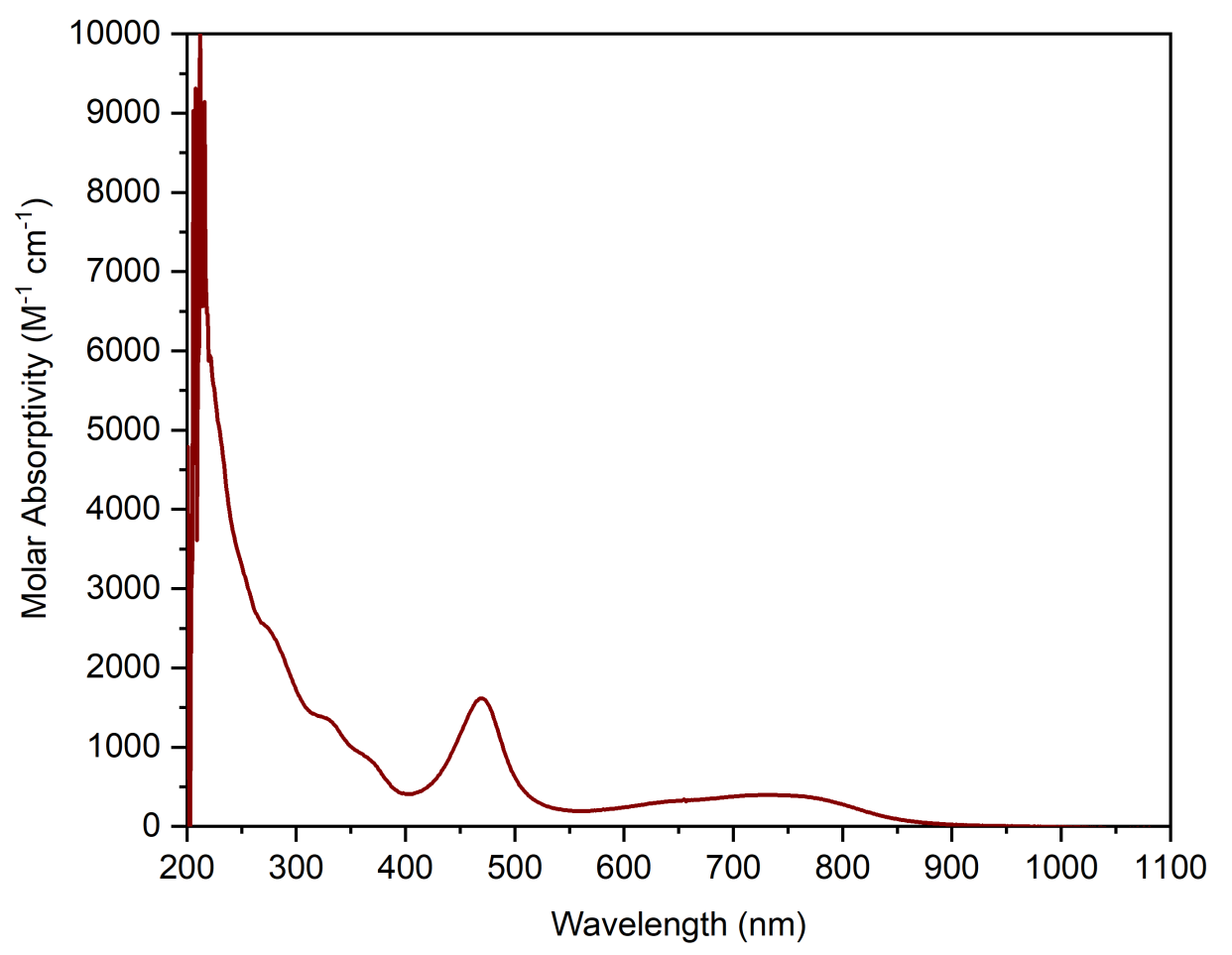

Figure S6F. UV-Visible spectrum (pentane, $25^{\circ} \mathrm{C}$ ) of 1. 

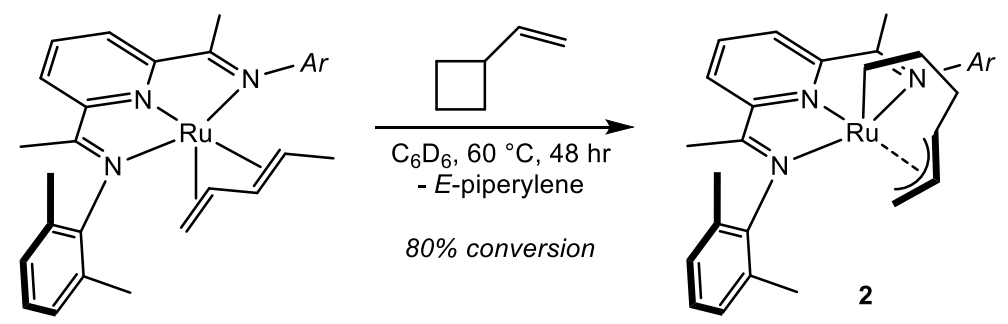

NMR-Scale Synthesis and Identification of 2. To a J. Young tube in the glove box was added a solution of $0.008 \mathrm{~g}(0.0142 \mathrm{mmol})$ of (MePDI)Ru(s-trans E-piperylene) in $0.600 \mathrm{~mL}$ of $\mathrm{C}_{6} \mathrm{D}_{6}$. The contents of the tube were sealed and frozen in liquid nitrogen after which $0.0213 \mathrm{mmol}(1.5$ equiv.) of vinylcyclobutane were added using a calibrated gas bulb. The contents of the tube were thawed in a room temperature water bath and placed in an oil bath at $60{ }^{\circ} \mathrm{C}$ for 48 hours. Reaction progress was monitored by ${ }^{1} \mathrm{H}$ NMR spectroscopy and reached $80 \%$ conversion after 48 hours. The tube was cooled to room temperature and brought into the glove box, after which the contents were transferred to a scintillation vial. The volatiles were removed under vacuum after which $\sim 0.800 \mathrm{~mL}$ of diethyl ether was added. The vial was placed in a $-35^{\circ} \mathrm{C}$ freezer from which deep green single crystals of 2 suitable for X-ray diffraction were obtained. Yield not determined. ${ }^{1} \mathrm{H}$ $\operatorname{NMR}\left(400 \mathrm{MHz}, \mathrm{C}_{6} \mathrm{D}_{6}\right) \delta 7.99(\mathrm{dd}, J=7.7,1.1 \mathrm{~Hz}, 1 \mathrm{H}), 7.83(\mathrm{dd}, J=7.7,0.8 \mathrm{~Hz}, 1 \mathrm{H}), 7.07$ (td, $J$ $=7.8,5.4 \mathrm{~Hz}, 3 \mathrm{H}), 6.98(\mathrm{t}, J=7.5 \mathrm{~Hz}, 1 \mathrm{H}), 6.96-6.86(\mathrm{~m}, 3 \mathrm{H}), 5.06-4.98(\mathrm{~m}, 1 \mathrm{H}), 4.94(\mathrm{t}, J=$ $1.6 \mathrm{~Hz}, 2 \mathrm{H}), 2.50-2.36(\mathrm{~m}, 4 \mathrm{H}), 2.21(\mathrm{~s}, 3 \mathrm{H}), 2.17(\mathrm{~s}, 3 \mathrm{H}), 2.11(\mathrm{~s}, 3 \mathrm{H}), 2.08(\mathrm{~s}, 3 \mathrm{H}), 1.38(\mathrm{~s}$, 3H), $1.30(\mathrm{~s}, 3 \mathrm{H}),-0.32(\mathrm{td}, J=9.2,5.0 \mathrm{~Hz}, 1 \mathrm{H}),-0.71(\mathrm{q}, J=7.8 \mathrm{~Hz}, 1 \mathrm{H})$. The ${ }^{1} \mathrm{H}$ NMR spectrum is given in Figure S7. 


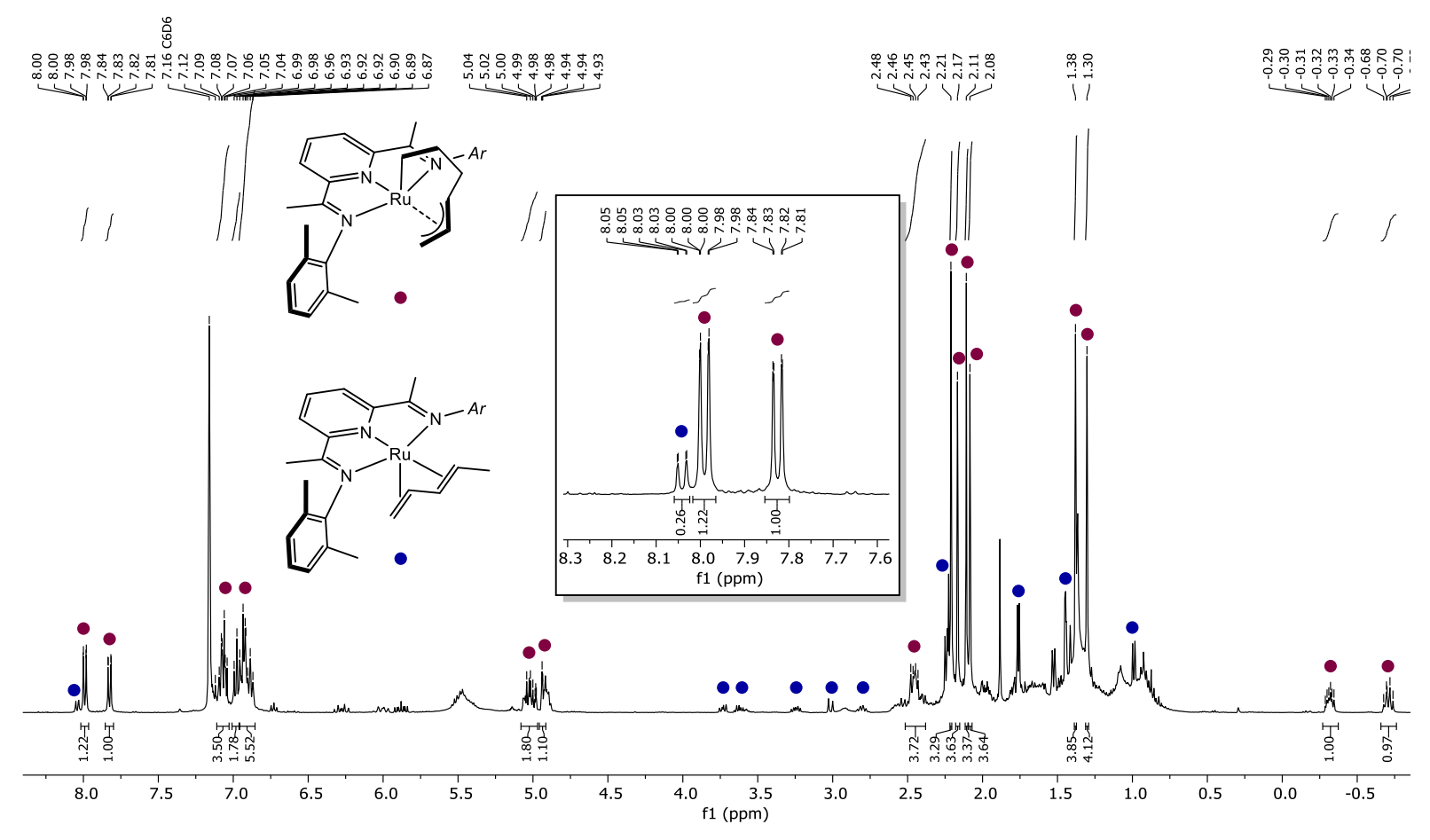

Figure S7. ${ }^{1} \mathrm{H}$ NMR $\left(400 \mathrm{MHz}, \mathrm{C}_{6} \mathrm{D}_{6}, 25^{\circ} \mathrm{C}\right.$ ) spectrum of 2 , as a $4: 1$ mixture of 2 (red circles) and (MePDI)Ru(strans E-piperylene) (blue circles). Inset: Peaks used for the determination of the ratio of 2 to (MePDI)Ru(s-trans E-piperylene). 


\section{General Procedure for the [2+2] Cycloaddition of Dienes and Ethylene}

General Procedure A: [2+2] Cycloaddition of Butadiene and Ethylene. In a typical experiment, a solution of catalyst $(0.022 \mathrm{mmol})$ and mesitylene internal standard $(0.010 \mathrm{~mL}$, $0.0718 \mathrm{mmol}$ ) in $0.600 \mathrm{~mL} \mathrm{C}_{6} \mathrm{D}_{6}$ were added to a $\mathrm{J}$. Young tube in a glove box. The tube was capped and the contents frozen in liquid nitrogen. $0.43 \mathrm{mmol}$ (20 equiv.) of butadiene, followed by $0.43 \mathrm{mmol}$ ( 20 equiv.) of ethylene were added to the tube using a calibrated gas bulb without thawing between gases. The tube was warmed to ambient temperature in a water bath after which the tube was mixed by inversion intermittently for 24 hours. The resulting product was then analyzed by ${ }^{1} \mathrm{H}$ NMR spectroscopy.

General Procedure B: [2+2] Cycloaddition of Piperylene and Ethylene. In a typical experiment, a solution of catalyst $(0.022 \mathrm{mmol})$ and mesitylene internal standard $(0.010 \mathrm{~mL}$, $0.0718 \mathrm{mmol}$ ) in $0.600 \mathrm{~mL} \mathrm{C}_{6} \mathrm{D}_{6}$ were added to a J. Young tube in a glove box. $0.43 \mathrm{mmol}$ (20 equiv.) of s-trans E-piperylene (as a $52 \%$ mixture of s-trans $E / Z$ piperylene and cyclopentene) was added to the tube. The tube was capped and frozen in liquid nitrogen. $0.43 \mathrm{mmol}$ (20 equiv.) of ethylene was added to the tube using a calibrated gas bulb. The tube was warmed to ambient temperature in a water bath, after which the tube was mixed by inversion intermittently for 24 hours. The resulting product was then analyzed by ${ }^{1} \mathrm{H}$ NMR spectroscopy. 


\section{Experiments Relevant to Diene Disposition}

CSD Search Criteria and Data. Qualifying s-cis or s-trans diolefin complexes were found using the structure search function in the Cambridge Structural Database (CSD) using the generic scaffold input shown in Figure S8A, where $\mathrm{M}$ is any transition metal, and dashed bonds denote any bond. Metallacyclopentane, metallacyclopentene, and obligate fused s-cis structures were omitted from the qualifying structures. 328 structures were found: 308 of which bound diolefins in an s-cis configuration, and 20 binding s-trans. The compiled data is shown in Figure S8B.

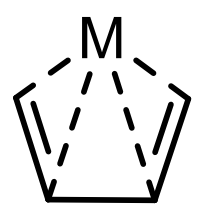

Figure S8A. Generic input structure for the CSD search. $M=$ any transition metal, dashed lines = any bond.

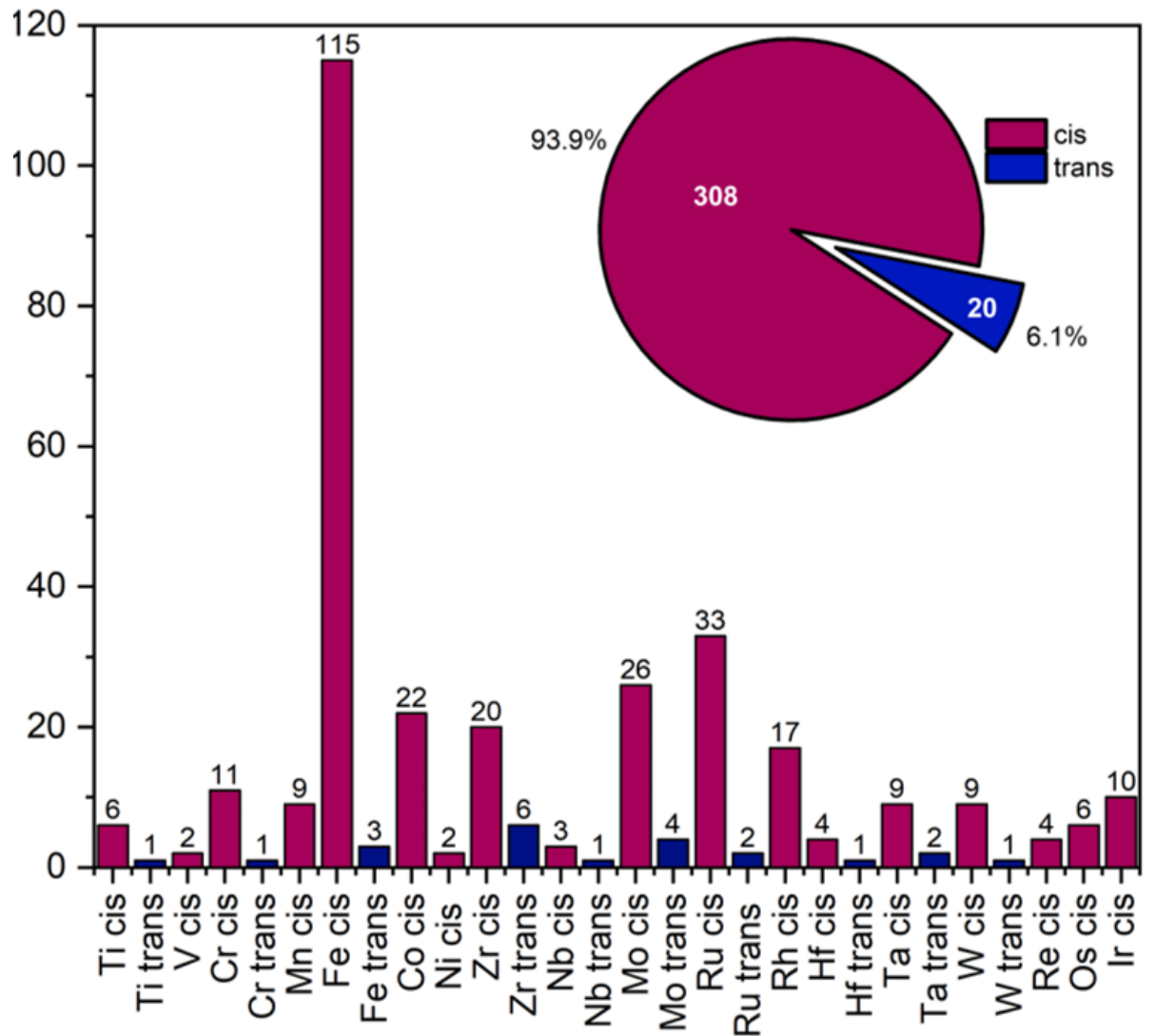

Figure S8B. Compiled data on number of qualifying structures found as a function of transition metal. Inset: global distribution on $s$-cis to $s$-trans diene ratio. 
Trigonal Bipyramidal vs. Square Pyramidal Bond Deviation Analysis. In order to determine the geometry of (PNP)Fe(s-cis $\left.\mathbf{C}_{4} \mathbf{H}_{6}\right)$ or $(\mathbf{P N N}) \mathbf{F e}\left(\right.$ s-cis $\left.\mathbf{C}_{4} \mathbf{H}_{6}\right)$ as either trigonal bipyramidal (TBP) or square pyramidal (SQP), the bond metrics of each crystallographically characterized species were compared to that of either idealized TBP or SQP structures. The total standard deviation $(\sigma)$ of each bond angle from the idealized structures was calculated and used as a basis for qualifying the geometry of the species analyzed. Centroids were used to represent the olefin units and were calculated using Mercury 2020.2.0 software.

For (PNP)Fe(s-cis $\mathbf{C}_{4} \mathbf{H}_{6}$ ), a TBP structure has an olefin and nitrogen of the pincer occupying the axial positions, with the other butadiene olefin and phosphorus atoms of the pincer occupying the equatorial positions (Figure S9A). In the SQP configuration, both olefin arms of the butadiene are in the basal plane along with one phosphorus and nitrogen atom of the pincer complex; the remaining phosphorus occupies the apical position. Comparing the bond metrics from the crystal structure of (PNP)Fe(s-cis $\left.\mathbf{C}_{4} \mathrm{H}_{6}\right)$ to either of these configurations indicates that the deviation from the TBP geometry is significantly less than that of SQP (Table S1 and S2). As such, (PNP)Fe(scis $\mathrm{C}_{4} \mathrm{H}_{6}$ ) is best represented as a TBP structure than a SQP structure.

Similarly, a TBP structure of (PNN)Fe(s-cis $\left.\mathbf{C}_{4} \mathbf{H}_{6}\right)$ has an olefin and alkyl bridge-substituted nitrogen of the pincer occupying the axial positions, with the other butadiene olefin, arylsubstituted nitrogen, and phosphorus atom of the pincer comprising the equatorial plane (Figure S9B). In the SQP configuration, both olefin arms of the butadiene are in the basal plane along with both nitrogen atoms. The phosphorus atom occupies the apical position. Comparing the deviation of the bond angles obtained from the crystal structure to both idealized geometries (Table S3 and S4) indicates that (PNN)Fe(s-cis $\left.\mathbf{C}_{4} \mathbf{H}_{6}\right)$ is also best represented as a TBP structure than a SQP structure. 


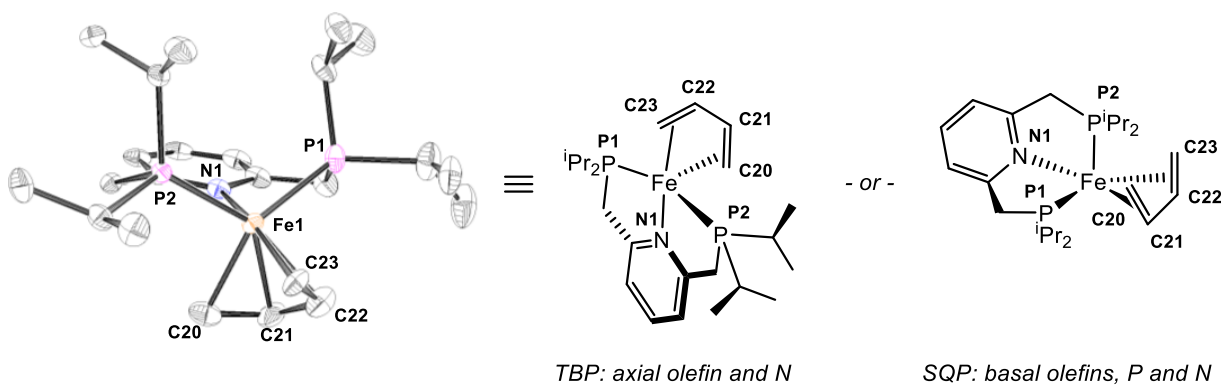

Figure S9A. Representations of (PNP)Fe(s-cis $\left.\mathrm{C}_{4} \mathrm{H}_{6}\right)$ in either a TBP geometry (left) or a SQP geometry (right).

Table S1. (PNP)Fe(s-cis $\mathbf{C}_{4} \mathrm{H}_{6}$ ) bond angle deviations from an idealized TBP geometry.

\begin{tabular}{cc}
\hline Angle & Crystal (Expected) \\
\hline N-Fe-centroid & $169.93^{\circ}\left(180^{\circ}\right)$ \\
P1-Fe-centroidEq & $128.44^{\circ}\left(120^{\circ}\right)$ \\
P2-Fe-centroidEq & $114.17^{\circ}\left(120^{\circ}\right)$ \\
P1-Fe-P2 & $116.14^{\circ}\left(120^{\circ}\right)$ \\
N-Fe-P1 & $80.14^{\circ}\left(90^{\circ}\right)$ \\
N-Fe-P2 & $83.45^{\circ}\left(90^{\circ}\right)$ \\
N-Fe-centroid ${ }^{\text {Eq }}$ & $95.16^{\circ}\left(90^{\circ}\right)$ \\
centroid ${ }^{\text {Ax }}$-Fe-P1 & $97.50^{\circ}\left(90^{\circ}\right)$ \\
centroid $^{\text {Ax }}$-Fe-P2 & $121.84^{\circ}\left(90^{\circ}\right)$ \\
centroid $^{\text {Ax }}$-Fe- centroid & $63.92^{\circ}\left(90^{\circ}\right)$ \\
\hline
\end{tabular}

$\sigma$

$14.62^{\circ}$

Centroid $^{\mathrm{Eq}}$ is defined as the center of the C22-C23 bond

Centroid $^{\mathrm{Ax}}$ is defined as the center of the $\mathrm{C} 20-\mathrm{C} 21$ bond

Table S2. (PNP)Fe(s-cis $\left.\mathrm{C}_{4} \mathrm{H}_{6}\right)$ bond angle deviations from an idealized SQP geometry.

\begin{tabular}{cc}
\hline Angle & Crystal (Expected) \\
\hline P1-Fe-centroid & $97.50^{\circ}\left(90^{\circ}\right)$ \\
P1-Fe-N & $80.14^{\circ}\left(90^{\circ}\right)$ \\
N-Fe-centroid ${ }^{2}$ & $95.16^{\circ}\left(90^{\circ}\right)$ \\
centroid $^{2}$-Fe-centroid & \\
P2-Fe-centroid & $63.92^{\circ}\left(90^{\circ}\right)$ \\
P2-Fe-centroid & $114.17^{\circ}\left(90^{\circ}\right)$ \\
P2-Fe-P1 & $121.84^{\circ}\left(90^{\circ}\right)$ \\
P2-Fe-N & $116.14^{\circ}\left(90^{\circ}\right)$ \\
\hline$\sigma$ & $83.45^{\circ}\left(90^{\circ}\right)$ \\
\hline
\end{tabular}

Centroid ${ }^{1}$ is defined as the center of the $\mathrm{C} 22-\mathrm{C} 23$ bond Centroid ${ }^{2}$ is defined as the center of the C20-C21 bond 


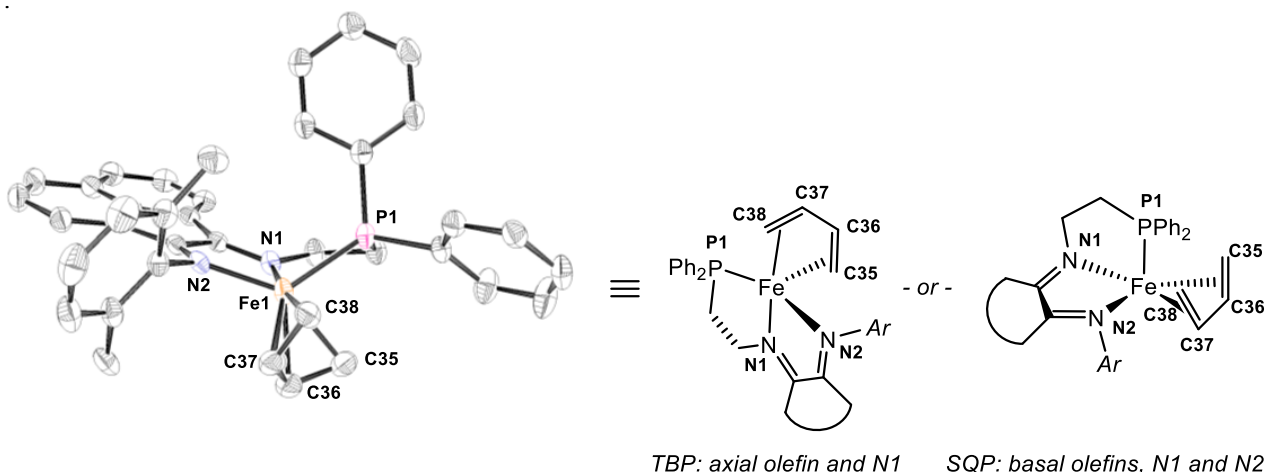

Figure S9B. Representations of (PNN)Fe(s-cis $\mathrm{C}_{4} \mathrm{H}_{6}$ ) in either a TBP geometry (left) or a SQP geometry (right).

Table S3. (PNN)Fe(s-cis $\mathrm{C}_{4} \mathrm{H}_{6}$ ) bond angle deviations from an idealized TBP geometry.

\begin{tabular}{cc}
\hline Angle & Crystal (Expected) \\
\hline N1-Fe-centroidaxial & $168.59^{\circ}\left(180^{\circ}\right)$ \\
P1-Fe-centroid ${ }^{\mathrm{Eq}}$ & $102.07^{\circ}\left(120^{\circ}\right)$ \\
P1-Fe-N2 & $127.09^{\circ}\left(120^{\circ}\right)$ \\
N2-Fe-centroidEq & $130.74^{\circ}\left(120^{\circ}\right)$ \\
centroid $^{\text {Ax }}$-Fe-centroid $\mathrm{Eq}$ & $65.11^{\circ}\left(90^{\circ}\right)$ \\
centroidAx-Fe-N2 $^{\text {Ax }}$ & $96.04^{\circ}\left(90^{\circ}\right)$ \\
centroidAx-Fe-P1 $^{\text {Ax }}$ & $110.95^{\circ}\left(90^{\circ}\right)$ \\
N1-Fe-centroidEq & $107.38^{\circ}\left(90^{\circ}\right)$ \\
N1-Fe-N2 & $82.46^{\circ}\left(90^{\circ}\right)$ \\
N1-Fe-P1 & $78.46^{\circ}\left(90^{\circ}\right)$ \\
\hline
\end{tabular}

$\sigma$

$14.84^{\circ}$

Centroid ${ }^{\mathrm{Eq}}$ is defined as the center of the C35-C36 bond Centroid $^{\mathrm{Ax}}$ is defined as the center of the C37-C38 bond

Table S4. (PNN)Fe(s-cis $\mathrm{C}_{4} \mathrm{H}_{6}$ ) bond angle deviations from an idealized SQP geometry.

\begin{tabular}{|c|c|}
\hline Angle & Crystal (Expected) \\
\hline N2-Fe-centroid ${ }^{1}$ & $96.04^{\circ}\left(90^{\circ}\right)$ \\
\hline centroid $^{1}$-Fe-centroid ${ }^{2}$ & $65.11^{\circ}\left(90^{\circ}\right)$ \\
\hline $\mathrm{Ni}-\mathrm{Fe}$-centroid ${ }^{2}$ & $107.38^{\circ}\left(90^{\circ}\right)$ \\
\hline $\mathrm{N} 1-\mathrm{Fe}-\mathrm{N} 2$ & $82.46^{\circ}\left(90^{\circ}\right)$ \\
\hline $\mathrm{P} 1-\mathrm{Fe}-\mathrm{N} 2$ & $127.09^{\circ}\left(90^{\circ}\right)$ \\
\hline $\mathrm{P} 1-\mathrm{Fe}-\mathrm{N} 1$ & $78.46^{\circ}\left(90^{\circ}\right)$ \\
\hline P1-Fe-centroid ${ }^{1}$ & $110.95^{\circ}\left(90^{\circ}\right)$ \\
\hline P1-Fe-centroid ${ }^{2}$ & $102.07^{\circ}\left(90^{\circ}\right)$ \\
\hline
\end{tabular}

Centroid ${ }^{1}$ is defined as the center of the C37-C38 bond Centroid ${ }^{2}$ is defined as the center of the C35-C36 bond 


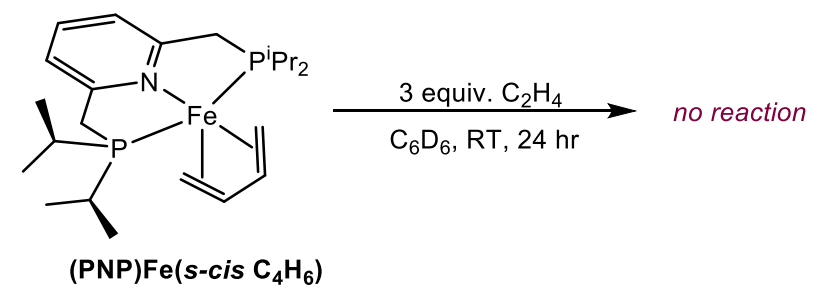

Stoichiometric Reactivity of (PNP)Fe(s-cis $\left.\mathrm{C}_{4} \mathrm{H}_{6}\right)$ with Ethylene. To a J. Young tube in the glove box was added a solution of $0.008 \mathrm{mg}(0.0178 \mathrm{mmol})(\mathrm{PNP}) \mathrm{Fe}\left(\mathrm{s}-\mathrm{cis} \mathrm{C}_{4} \mathrm{H}_{6}\right)$ in $0.600 \mathrm{~mL}$ $\mathrm{C}_{6} \mathrm{D}_{6}$. The tube was sealed and frozen in liquid nitrogen. $0.0534 \mathrm{mmol}$ of ethylene (3 equiv.) of ethylene was added using a calibrated gas bulb. The tube was thawed in a room temperature water bath, and the tube was mixed by inversion for 24 hours at room temperature. The reaction was analyzed intermittently by ${ }^{1} \mathrm{H}$ and ${ }^{31} \mathrm{P}\left\{{ }^{1} \mathrm{H}\right\}$ NMR. Although broadening of the ethylene peak was observed, the speciation of $\mathrm{Fe}$ in situ was found to be (PNP)Fe(s-cis $\left.\mathrm{C}_{4} \mathrm{H}_{6}\right)$, with no evidence for the formation of metallacyclic or paramagnetic products. The ${ }^{1} \mathrm{H}$ and ${ }^{31} \mathrm{P}\left\{{ }^{1} \mathrm{H}\right\}$ NMR data are given in Figure S10A and S10B, respectively. 


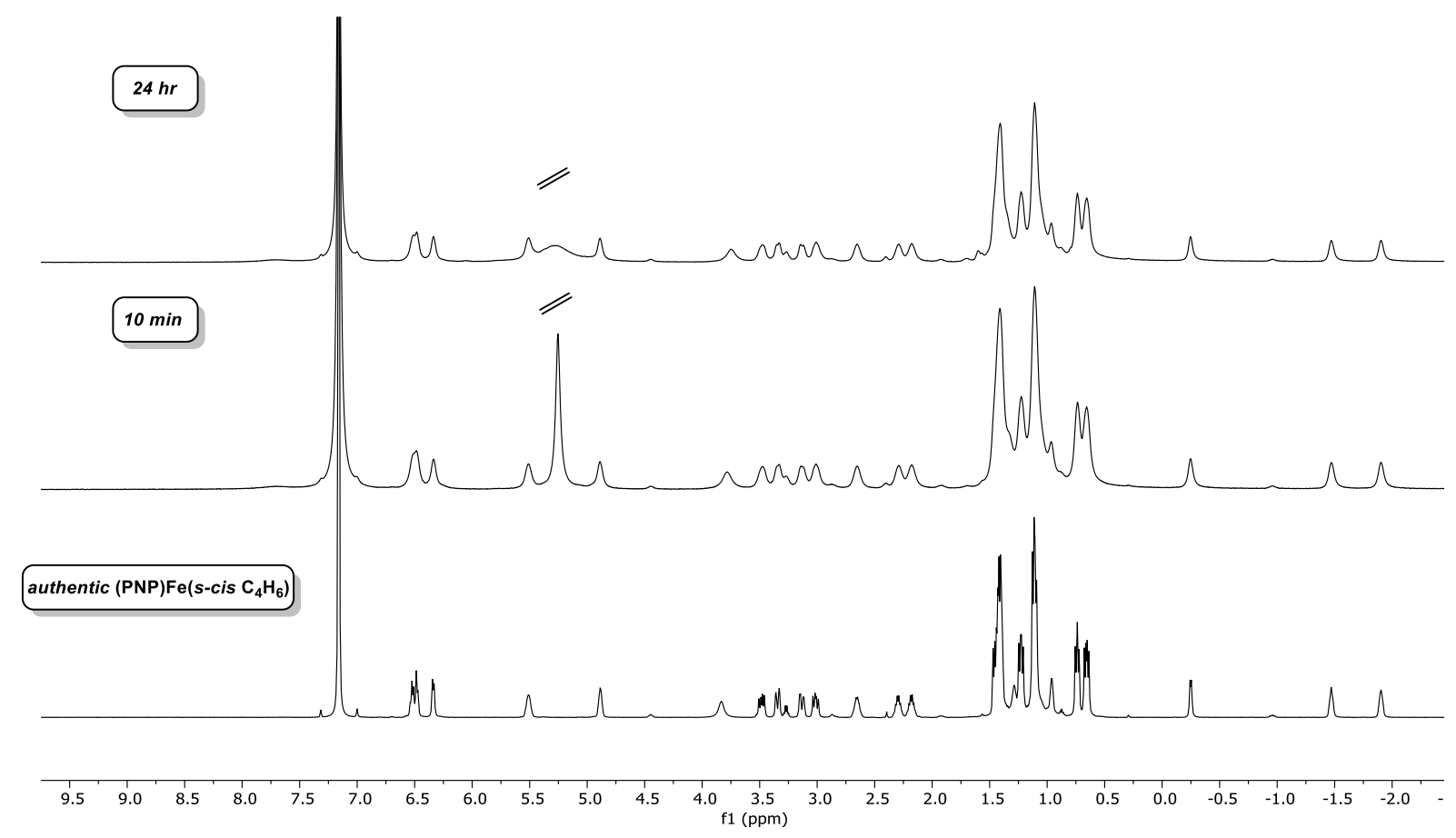

Figure S10A. ${ }^{1} \mathrm{H}$ NMR $\left(500 \mathrm{MHz}, \mathrm{C}_{6} \mathrm{D}_{6}, 25^{\circ} \mathrm{C}\right)$ spectra of the reaction of (PNP)Fe(s-cis $\left.\mathbf{C}_{4} \mathrm{H}_{6}\right)$ with superstoichiometric ethylene at 10 minutes and 24 hours of reaction time. The spectrum of authentic (PNP)Fe(scis $\mathrm{C}_{4} \mathrm{H}_{6}$ ) is provided for comparison.
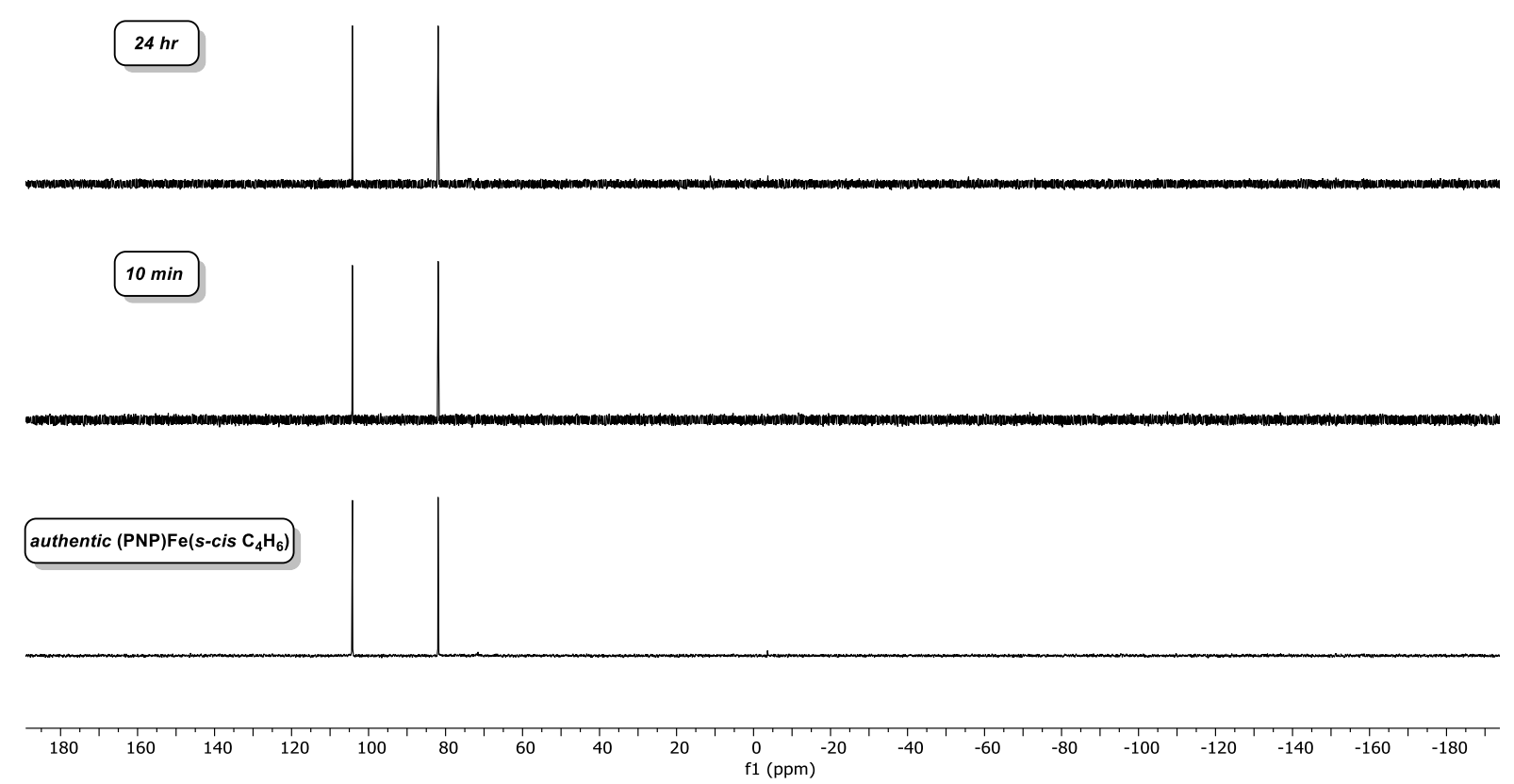

Figure S10B. ${ }^{31} \mathrm{P}\left\{{ }^{1} \mathrm{H}\right\}$ NMR $\left(202 \mathrm{MHz}, \mathrm{C}_{6} \mathrm{D}_{6}, 25^{\circ} \mathrm{C}\right)$ spectra of the reaction of (PNP)Fe(s-cis $\left.\mathrm{C}_{4} \mathrm{H}_{6}\right)$ with superstoichiometric ethylene at 10 minutes and 24 hours of reaction time. The spectrum of authentic (PNP)Fe(scis $\mathrm{C}_{4} \mathrm{H}_{6}$ ) is provided for comparison. 


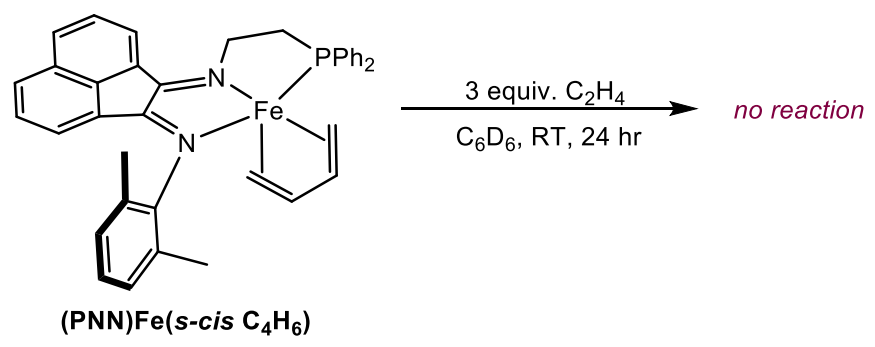

Stoichiometric Reactivity of (PNN)Fe(s-cis $\left.\mathrm{C}_{4} \mathrm{H}_{6}\right)$ with Ethylene. To a J. Young tube in the glove box was added a solution of $0.008 \mathrm{mg}(0.0132 \mathrm{mmol})(\mathbf{P N N}) \mathrm{Fe}\left(\boldsymbol{s}\right.$-cis $\left.\mathbf{C}_{4} \mathrm{H}_{6}\right)$ in $0.600 \mathrm{~mL}$ $\mathrm{C}_{6} \mathrm{D}_{6}$. The tube was sealed and the contents frozen in liquid nitrogen. $0.0396 \mathrm{mmol}$ of ethylene (3 equiv.) of ethylene was added using a calibrated gas bulb. The contents of the tube were thawed in a room temperature water bath and the tube was mixed by inversion for 24 hours at room temperature. The reaction was analyzed intermittently by ${ }^{1} \mathrm{H}$ NMR spectroscopy. The identity of the iron product was found to be (PNP)Fe(s-cis $\left.\mathrm{C}_{4} \mathrm{H}_{6}\right)$ with no evidence for the formation of metallacyclic or paramagnetic products. No broadening of the ethylene resonance was observed. The ${ }^{1} \mathrm{H}$ NMR data and ${ }^{31} \mathrm{P}\left\{{ }^{1} \mathrm{H}\right\}$ NMR are presented in Figures S11A and S11B, respectively. 


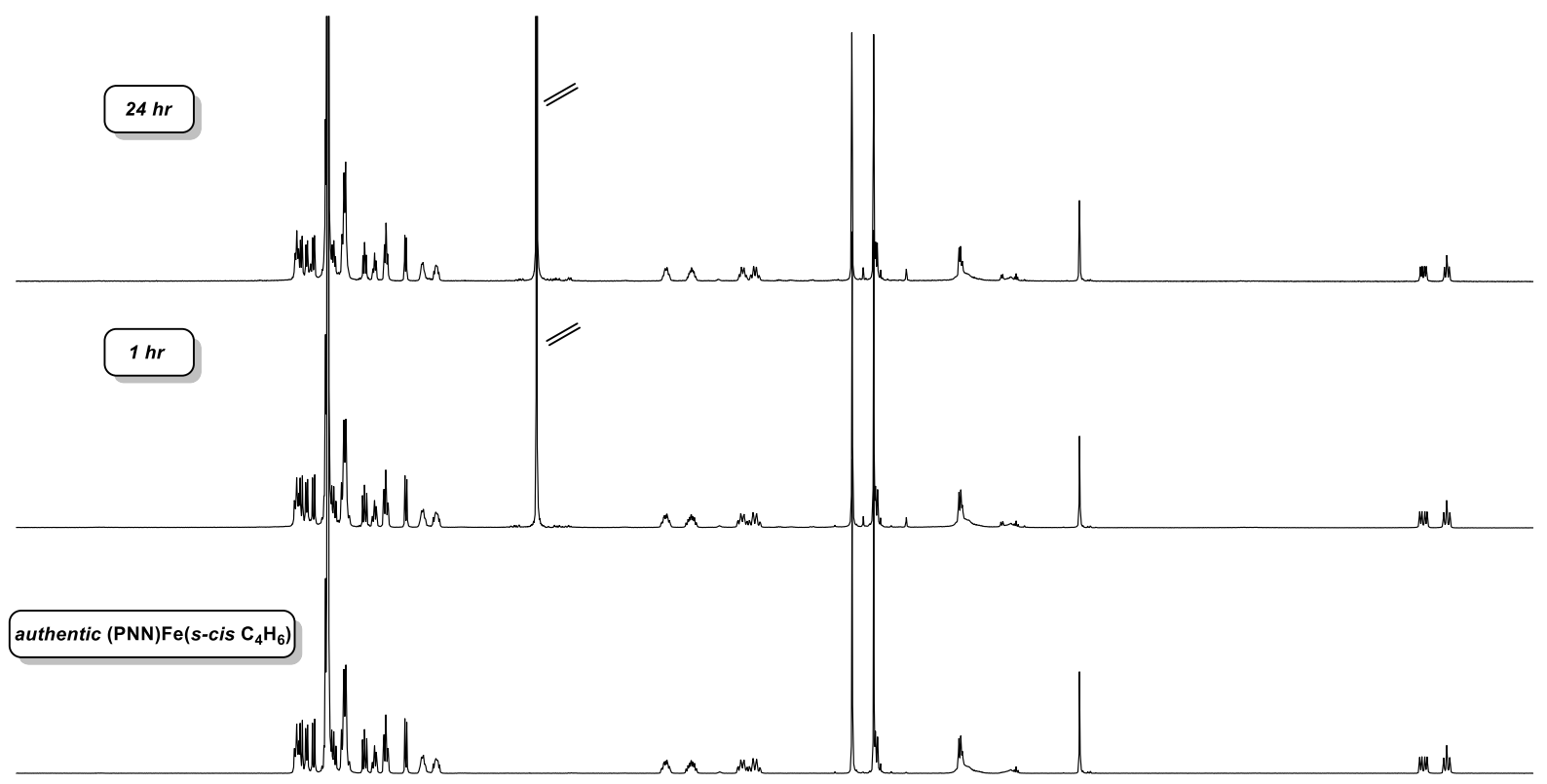

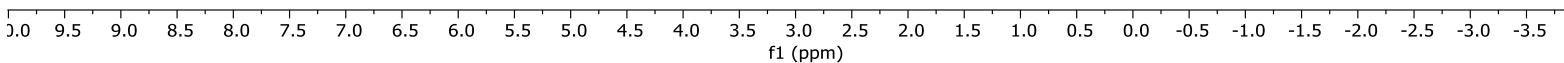

Figure S11A. ${ }^{1} \mathrm{H}$ NMR (500 MHz, $\left.\mathrm{C}_{6} \mathrm{D}_{6}, 25{ }^{\circ} \mathrm{C}\right)$ spectra of the reaction of (PNN)Fe(s-cis $\left.\mathrm{C}_{4} \mathrm{H}_{6}\right)$ with superstoichiometric ethylene at 1 hour and 24 hours of reaction time. The spectrum of authentic (PNN)Fe(s-cis $\mathbf{C}_{4} \mathrm{H}_{6}$ ) is provided for comparison.
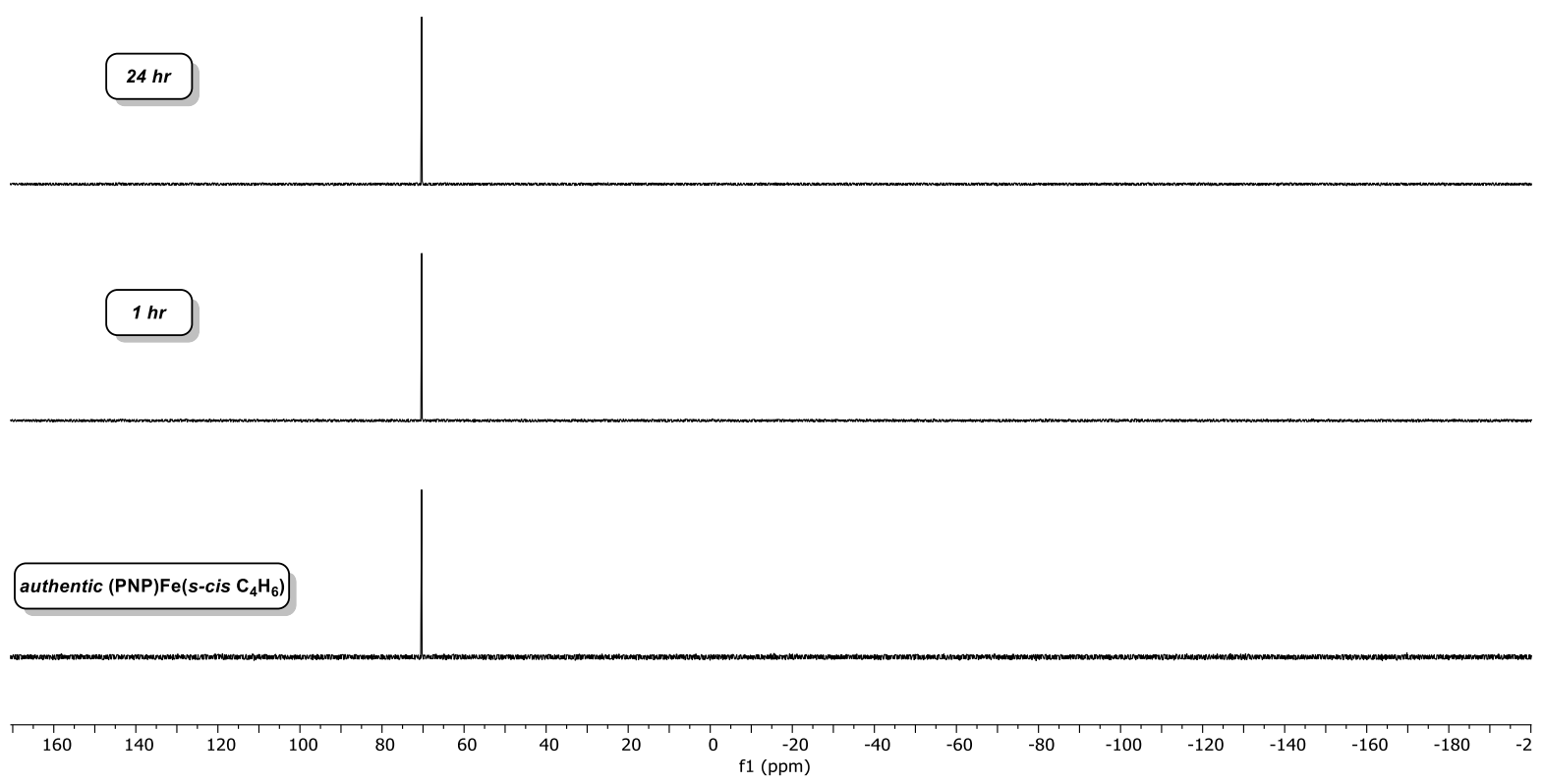

Figure S11B. ${ }^{31} \mathrm{P}\left\{{ }^{1} \mathrm{H}\right\}$ NMR $\left(202 \mathrm{MHz}, \mathrm{C}_{6} \mathrm{D}_{6}, 25^{\circ} \mathrm{C}\right)$ spectra of the reaction of (PNN)Fe(s-cis $\left.\mathbf{C}_{4} \mathrm{H}_{6}\right)$ with superstoichiometric ethylene at 10 minutes and 24 hours of reaction time. The spectrum of authentic (PNN)Fe(scis $\mathrm{C}_{4} \mathrm{H}_{6}$ ) is provided for comparison. 


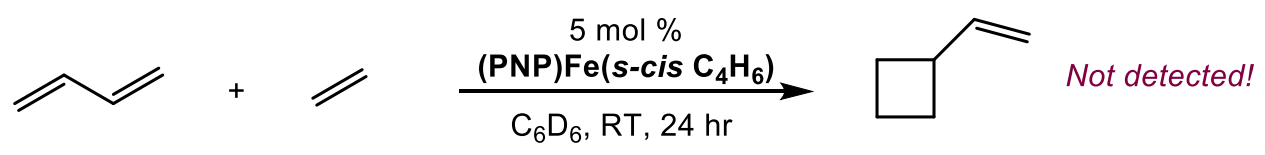

Catalytic Competence of (PNP)Fe(s-cis $\left.\mathrm{C}_{4} \mathrm{H}_{6}\right)$ in [2+2] Cycloaddition. A J. Young tube was prepared as described in General Procedure A: [2+2] Cycloaddition of Butadiene and Ethylene. After 24 hours of reaction time, the reaction was analyzed by ${ }^{1} \mathrm{H}$ NMR spectroscopy. No evidence for the formation of vinylcyclobutane or consumption of butadiene and ethylene was obtained. The identity of the iron after 24 hours was solely (PNP)Fe(s-cis $\mathrm{C}_{4} \mathrm{H}_{6}$ ). The ${ }^{1} \mathrm{H}$ NMR spectrum of the reaction mixture is presented in Figure S12.
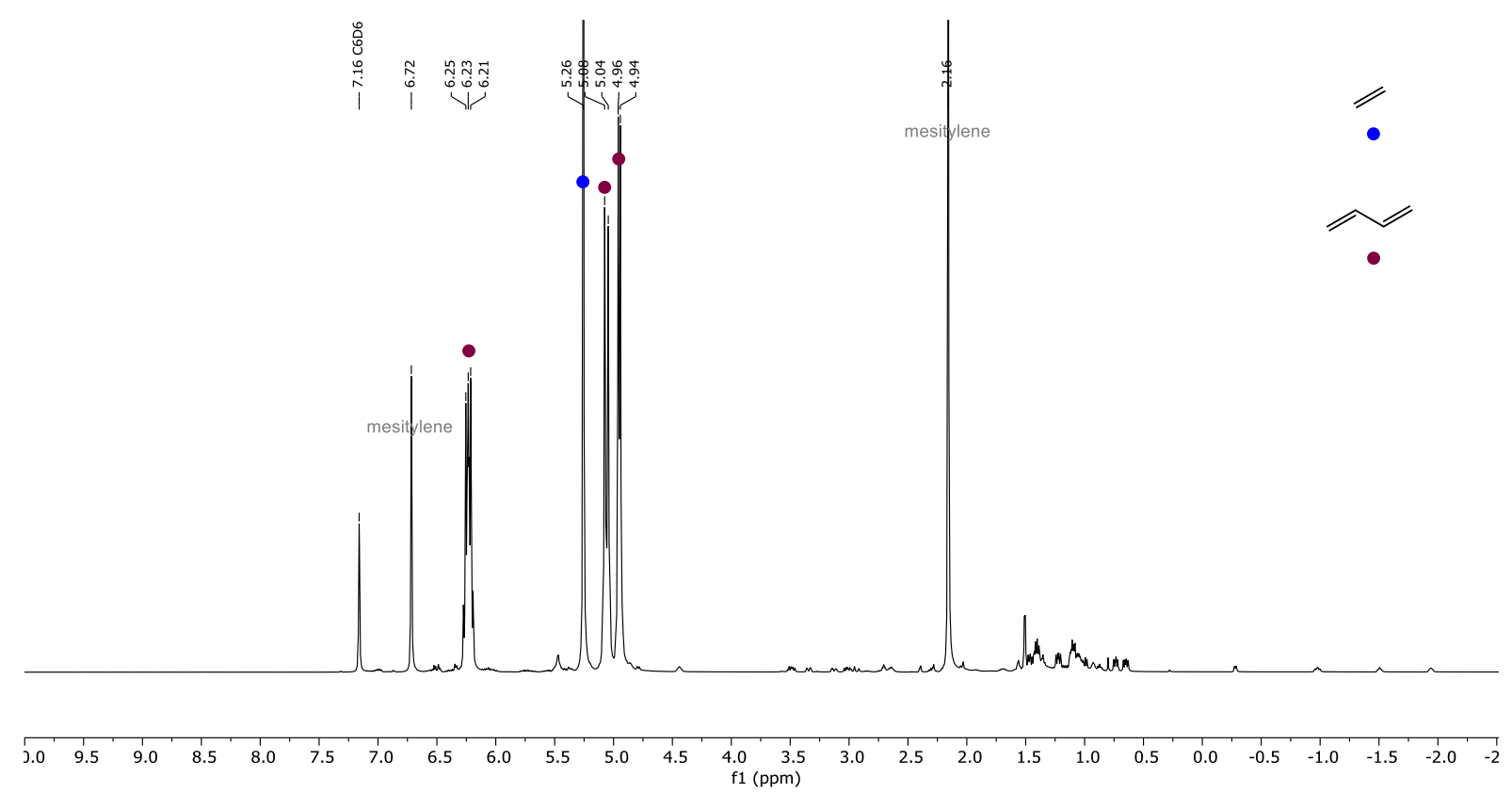

Figure S12. ${ }^{1} \mathrm{H}$ NMR $\left(500 \mathrm{MHz}, \mathrm{C}_{6} \mathrm{D}_{6}, 25^{\circ} \mathrm{C}\right.$ ) spectrum of the reaction of butadiene and ethylene catalyzed by (PNP)Fe(s-cis $\left.\mathrm{C}_{4} \mathrm{H}_{6}\right)$ after 24 hours of reaction time. Assignments of organic products are given. 


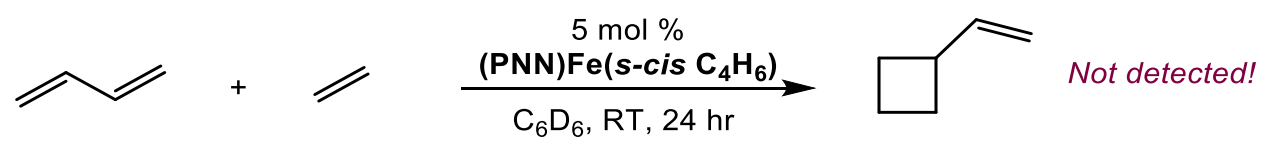

Catalytic Competence of $(\mathrm{PNN}) \mathrm{Fe}\left(\mathrm{s}-\mathrm{cis} \mathrm{C}_{4} \mathrm{H}_{6}\right)$ in [2+2] Cycloaddition. A J. Young tube was prepared as described in General Procedure A: [2+2] Cycloaddition of Butadiene and Ethylene. After 24 hours of reaction time, the reaction was analyzed by ${ }^{1} \mathrm{H}$ NMR spectroscopy. No evidence for the formation of vinylcyclobutane or consumption of butadiene and ethylene was observed. The identity of the iron after 24 hours was solely (PNN)Fe(s-cis $\left.\mathbf{C}_{4} \mathbf{H}_{6}\right)$. The ${ }^{1} \mathrm{H}$ NMR spectrum of the reaction mixture is presented in Figure S13.

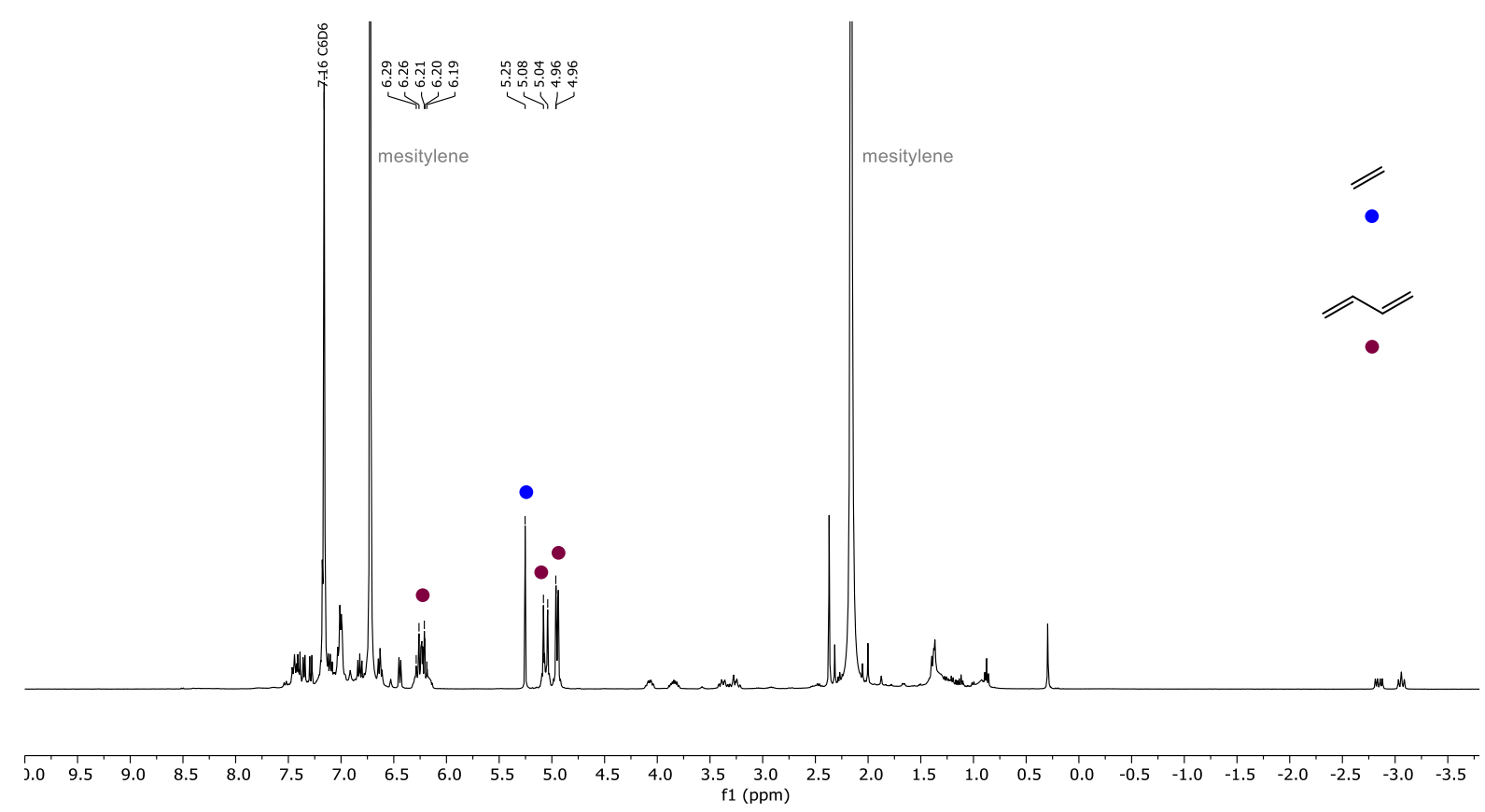

Figure S12. ${ }^{1} \mathrm{H}$ NMR (400 MHz, $\left.\mathrm{C}_{6} \mathrm{D}_{6}, 25^{\circ} \mathrm{C}\right)$ spectrum of the reaction of butadiene and ethylene catalyzed by (PNN)Fe(s-cis $\mathrm{C}_{4} \mathrm{H}_{6}$ ) after 24 hours of reaction time. Assignments of organic products are given. 


\section{Experiments Relevant to Diene Dynamics}

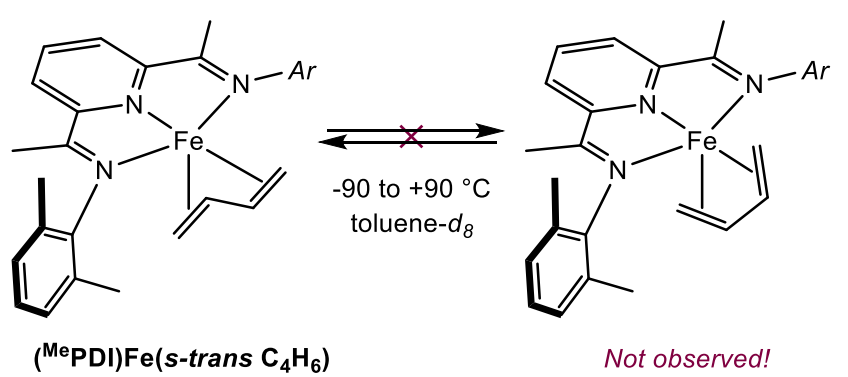

Variable Temperature NMR Study of ( ${ }^{\text {MePDI}}$ )Fe(s-trans $\left.\mathrm{C}_{4} \mathrm{H}_{6}\right)$. To a J. Young tube in the glove box was added a solution of $0.008 \mathrm{~g}(0.0167 \mathrm{mmol})$ of (MePDI)Fe(s-trans $\left.\mathrm{C}_{4} \mathrm{H}_{6}\right)$ in $0.600 \mathrm{~mL}$ of toluene- $d_{8}$. The tube was capped and analyzed by ${ }^{1} \mathrm{H}$ NMR spectroscopy at $25^{\circ} \mathrm{C}$ then at $10{ }^{\circ} \mathrm{C}$ followed by $10{ }^{\circ} \mathrm{C}$ decreasing increments to $-90{ }^{\circ} \mathrm{C}$. 5-minute intervals were allowed between scans to equilibrate the solution temperature. The tube was brought back to room temperature, then analyzed in $10^{\circ} \mathrm{C}$ increasing increments to a temperature of $+90^{\circ} \mathrm{C}$. The compiled data are reported in Figure S13.

Analysis of the VT-NMR data indicate that there is no change in, or appearance of, new butadiene signals. The only observable dynamic occurs in the aryl groups appended to the nitrogen atoms at $\sim 6.80$ and $\sim 1.5 \mathrm{ppm}$, which coalesce at a temperature of $60^{\circ} \mathrm{C}$. The coalescence of the flanking aryl groups suggests an increase in rotation rate that equilibrates the appended methyl groups. Above $60^{\circ} \mathrm{C}$, decomposition of the complex is observed. Taken together, there does not appear to be a thermally accessible $s$-cis diolefin isomer of $\left({ }^{\text {Me}} \mathbf{P D I}\right) \mathrm{Fe}\left(\boldsymbol{s}\right.$-trans $\left.\mathrm{C}_{4} \mathrm{H}_{6}\right)$. 


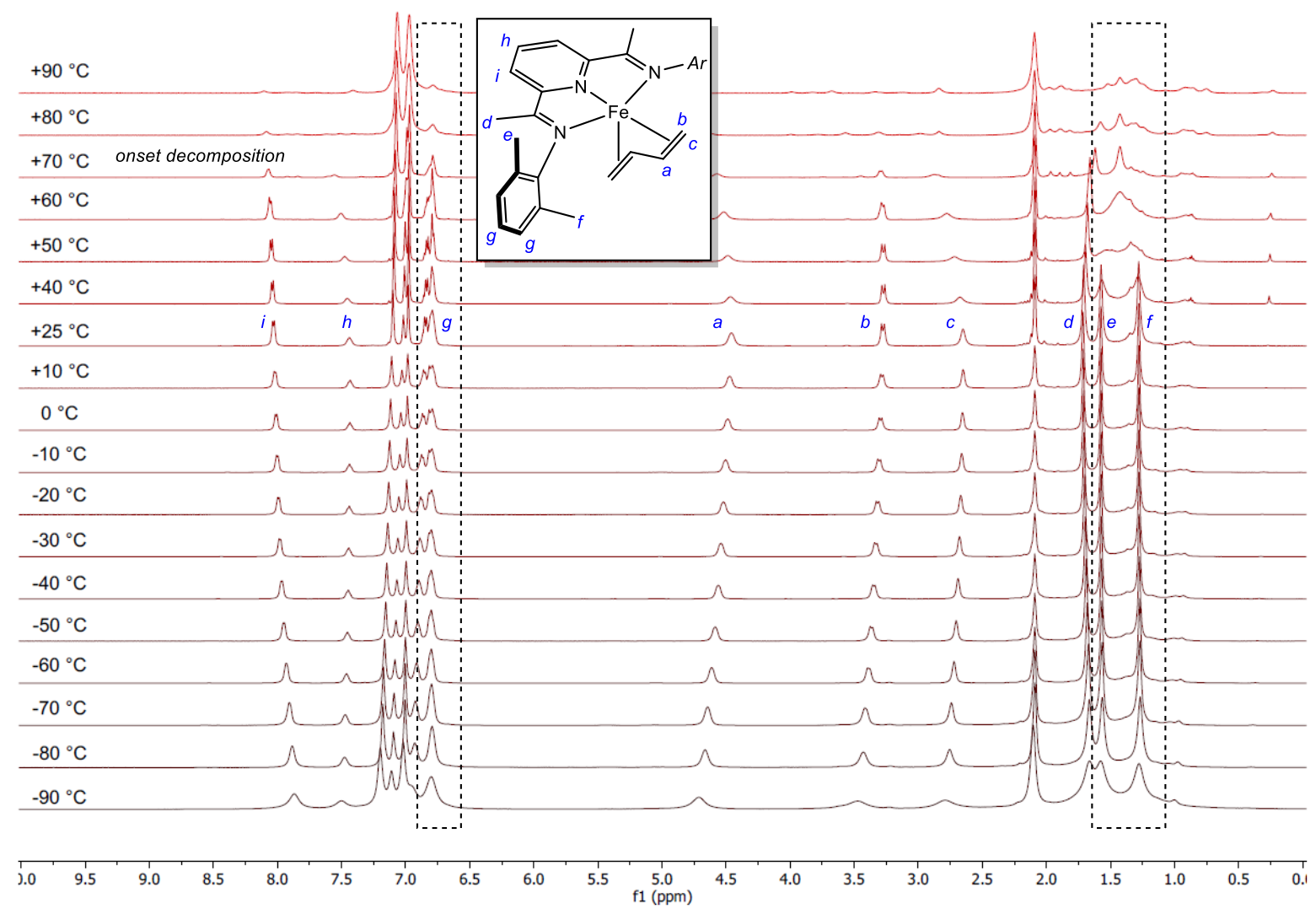

Figure S13. Variable temperature ${ }^{1} \mathrm{H}$ NMR $\left(500 \mathrm{MHz}, \mathrm{C}_{6} \mathrm{D}_{6}\right.$ ) spectra of (MePDI)Fe(s-trans $\mathrm{C}_{4} \mathrm{H}_{6}$ ). Assignment of the room temperature $\left(25^{\circ} \mathrm{C}\right)$ spectrum is given. Coalescence of the aryl groups is shown in the dotted boxes. 


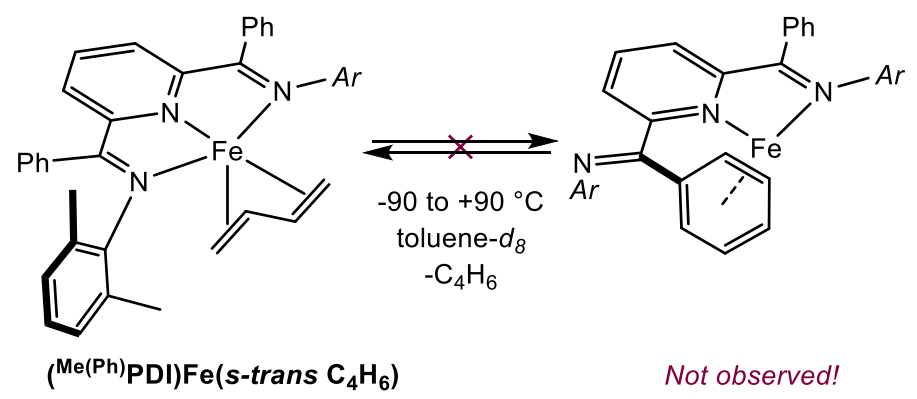

Variable Temperature NMR of $\left({ }^{\mathrm{Me}(\mathrm{Ph})} \mathrm{PDI}\right) \mathrm{Fe}\left(\mathrm{s}\right.$-trans $\left.\mathrm{C}_{4} \mathrm{H}_{6}\right)$. To a J. Young tube in the glove box was added a solution of $0.010 \mathrm{~g}(0.0167 \mathrm{mmol})$ of $\left({ }^{\mathrm{Me}(\mathrm{Ph})} \mathrm{PDI}\right) \mathrm{Fe}\left(\mathrm{s}\right.$-trans $\left.\mathrm{C}_{4} \mathrm{H}_{6}\right)$ in $0.600 \mathrm{~mL}$ of toluene- $d_{8}$. The tube was capped and analyzed by ${ }^{1} \mathrm{H}$ NMR spectroscopy at $25^{\circ} \mathrm{C}$, then at $10{ }^{\circ} \mathrm{C}$ followed by $10^{\circ} \mathrm{C}$ decreasing increments to $-90^{\circ} \mathrm{C}$. 5-minute intervals were allowed between scans to equilibrate the solution temperature. The tube was brought back to room temperature, then analyzed in $10^{\circ} \mathrm{C}$ increasing increments to a temperature of $+90^{\circ} \mathrm{C}$. The compiled data are given in Figure S14.

Analysis of the VT-NMR data indicate that there is no change in the complex to the $\eta^{6}$-bound aryl complex. Further, no signals attributable to the thermal population of an s-cis diolefin variant are observed, as there is no change in the resonances corresponding to the bound butadiene. The flanking aryl groups on the imine nitrogen atoms are coalesced at $25^{\circ} \mathrm{C}$, but can be resolved upon cooling below $10^{\circ} \mathrm{C}$. Similarly, the backbone phenyl groups have restricted rotation below $0{ }^{\circ} \mathrm{C}$, allowing for resolution of the ortho/meta and para positions. Above $+80^{\circ} \mathrm{C}$, the complex decomposes, such that this species is slightly more thermally robust than (MePDI)Fe(s-trans $\left.\mathrm{C}_{4} \mathrm{H}_{6}\right)$. Nevertheless, the lack of deactivation by imine arm dissociation implies that the imine units do not dissociate from the Fe center at catalytically relevant temperatures. 

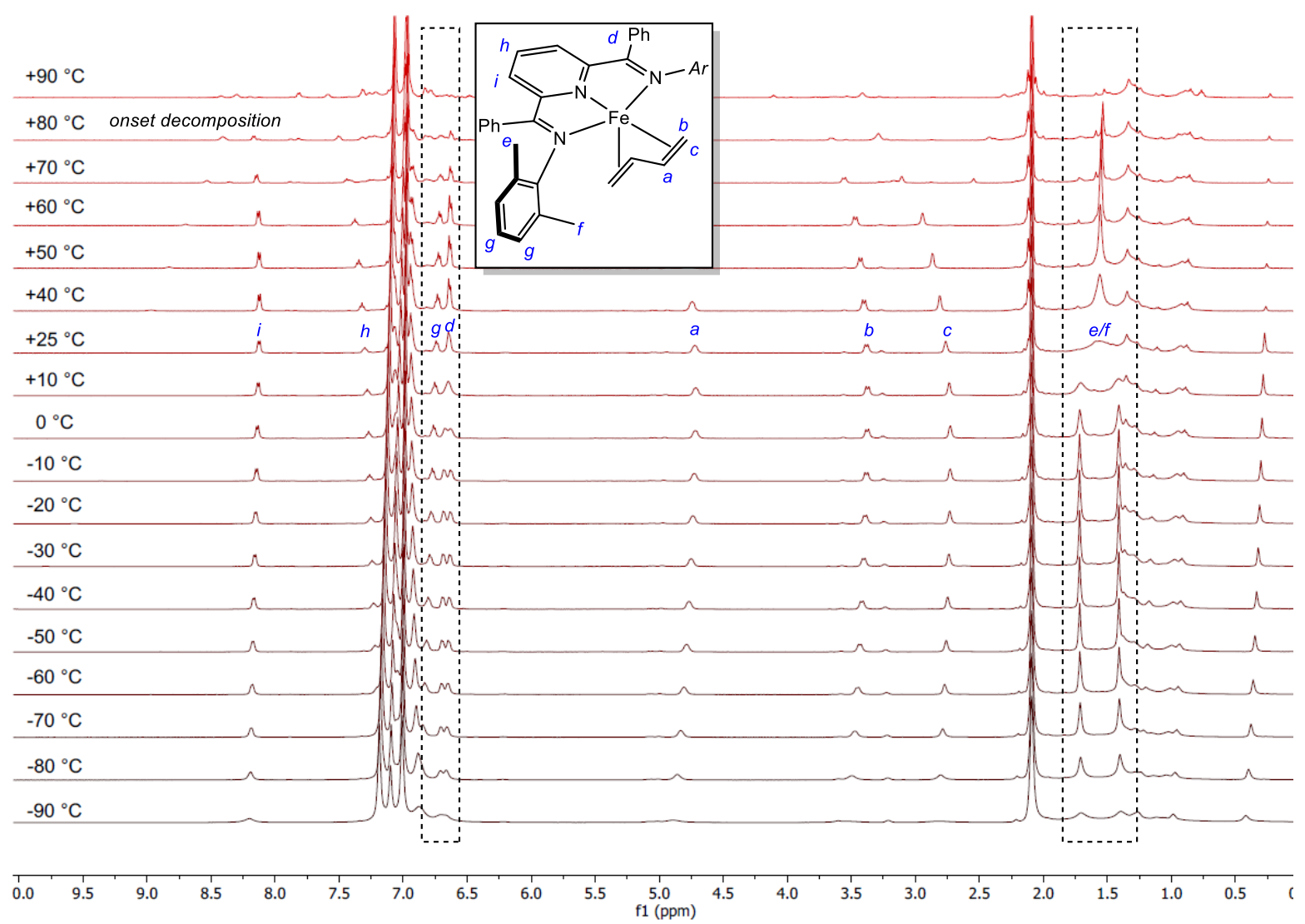

Figure S13. Variable temperature ${ }^{1} \mathrm{H}$ NMR $\left(500 \mathrm{MHz}, \mathrm{C}_{6} \mathrm{D}_{6}\right)$ spectra of ( $\left.{ }^{\mathrm{Me}(\mathrm{Ph})} \mathrm{PDI}\right) \mathrm{Fe}\left(\mathrm{s}\right.$-trans $\left.\mathrm{C}_{4} \mathrm{H}_{6}\right)$. Assignment of the room temperature $\left(25^{\circ} \mathrm{C}\right)$ spectrum is given. Coalescence of the aryl groups is shown in the dotted boxes. 


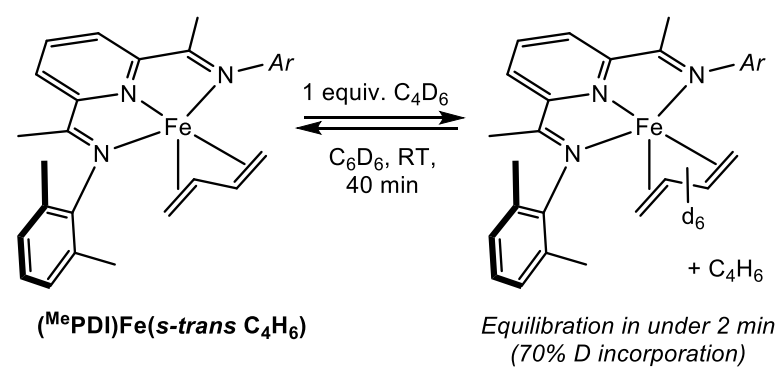

Exchange Experiments: ( $\left.{ }^{\mathrm{Me}} \mathrm{PDI}\right) \mathrm{Fe}\left(\mathrm{s}\right.$-trans $\mathrm{C}_{4} \mathrm{H}_{6}$ ) with Butadiene- $\boldsymbol{d}_{6}$. To a J. Young tube in the glove box was added a solution of $0.008 \mathrm{~g}(0.0167 \mathrm{mmol})$ of (MePDI)Fe(s-trans $\left.\mathrm{C}_{4} \mathrm{H}_{6}\right)$ in $0.600 \mathrm{~mL}$ of $\mathrm{C}_{6} \mathrm{D}_{6}$. The tube was capped and the contents frozen in liquid nitrogen after which $0.0167 \mathrm{mmol}$ ( 1 equiv.) of butadiene- $d_{6}$ was added using a calibrated gas bulb. The tube was kept frozen en route to the NMR instrument after which the contents were thawed, mixed twice by inversion, then analyzed by ${ }^{1} \mathrm{H}$ NMR spectroscopy intermittently over a 40 -minute timeframe. The presence of free natural abundance butadiene in the ${ }^{1} \mathrm{H}$ NMR spectrum indicated exchange of butadiene, which was quantified as conversion relative to the signals corresponding to natural abundance butadiene coordinated to the iron. Quantifying free/bound butadiene as a function of time indicated no change in signal integrations after the initial timepoint, indicating that equilibration happens rapidly upon thawing and mixing of the solution. The initial ${ }^{1} \mathrm{H}$ NMR spectrum is given in Figure S14A. The full data set of percent butadiene- $d_{6}$ incorporation as a function of time is presented in Figure S14B. 


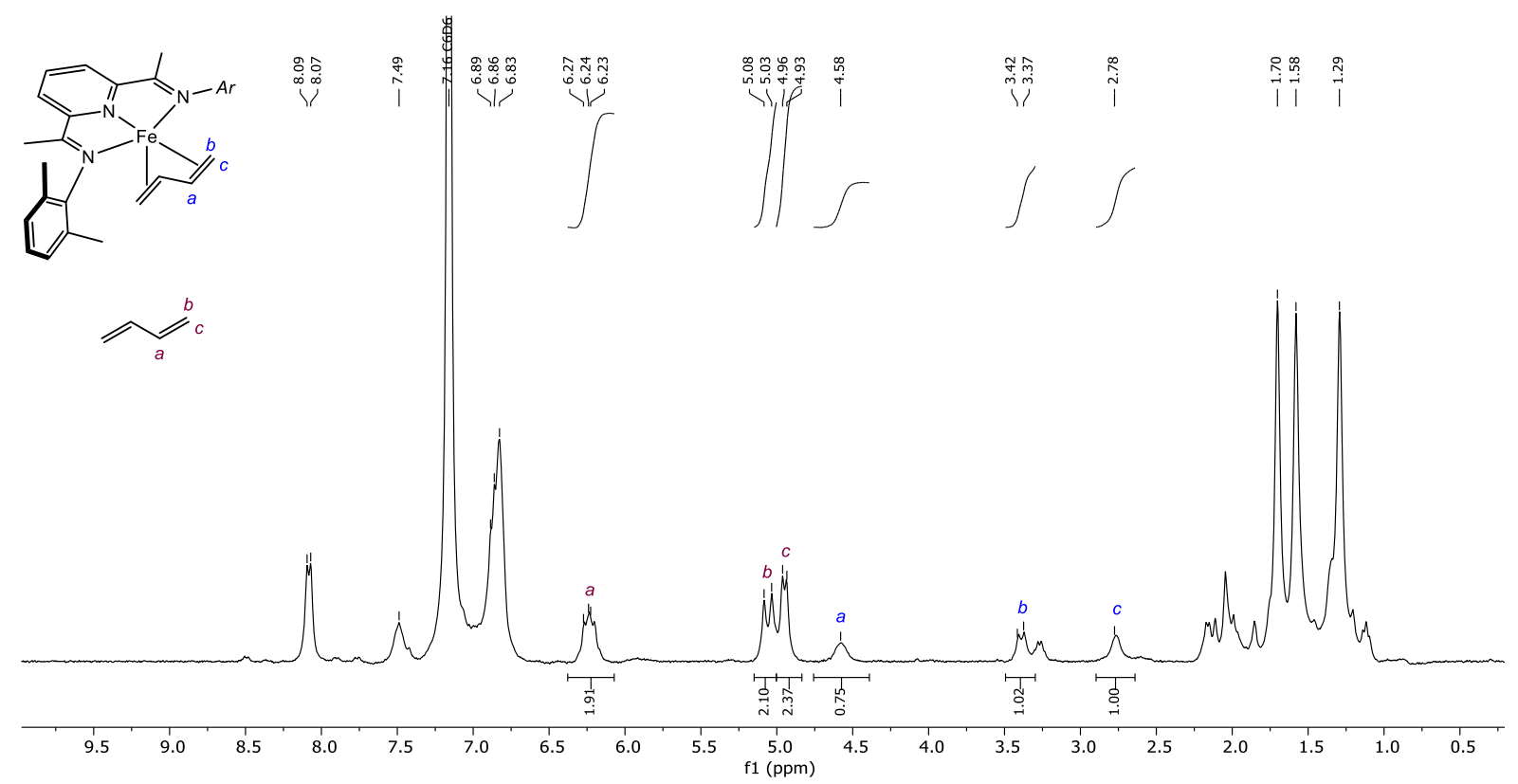

Figure S14A. ${ }^{1} \mathrm{H}$ NMR $\left(500 \mathrm{MHz}, \mathrm{C}_{6} \mathrm{D}_{6}, 25{ }^{\circ} \mathrm{C}\right)$ spectra of the reaction of (MePDI)Fe(s-trans $\left.\mathrm{C}_{4} \mathrm{H}_{6}\right)$ with stoichiometric butadiene- $d_{6}$ at the initial ( $\left.\sim 2 \mathrm{~min}\right)$ timepoint. Assignment of the protio-butadiene moieties is given.

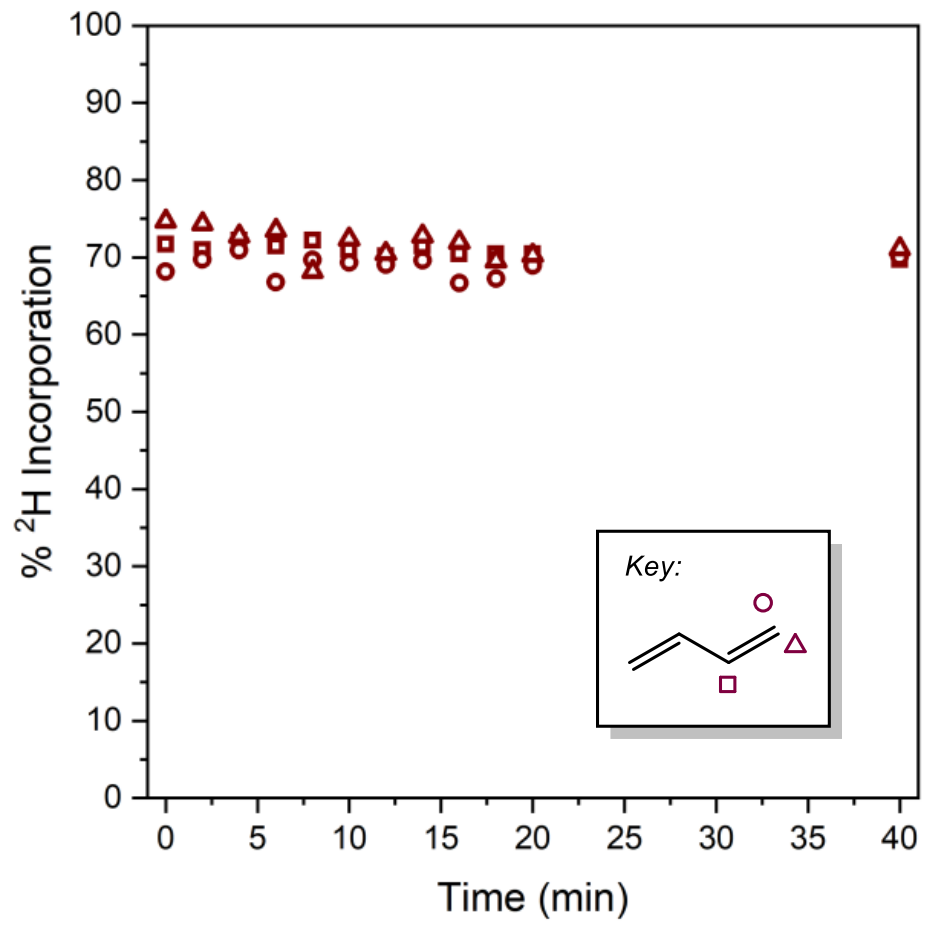

Figure S14B. Percent butadiene- $d_{6}$ incorporation plotted as a function of time, indicating equilibration at the initial timepoint. Inset: key of butadiene signals used to assess percent incorporation of labeled butadiene. 


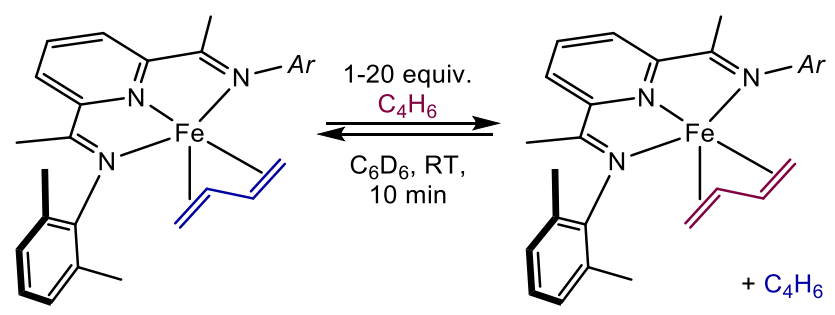

EXSY Experiments. To a J. Young tube in the glove box was added a solution of $0.012 \mathrm{~g}(0.0240$ mmol) of ( $\left.{ }^{\mathrm{Me}} \mathrm{PDI}\right) \mathrm{Fe}\left(\mathbf{s}\right.$-trans $\mathrm{C}_{4} \mathrm{H}_{6}$ ) in $0.600 \mathrm{~mL}$ of $\mathrm{C}_{6} \mathrm{D}_{6}$. The tube was capped and the contents frozen in liquid nitrogen after which $0.0240 \mathrm{mmol}$ (1 equiv.) of butadiene were added using a calibrated gas bulb. The contents of the tube were thawed in a room temperature water bath, then mixed by inversion intermittently for ten minutes. The reaction mixture was analyzed by ${ }^{1} \mathrm{H}-{ }^{1} \mathrm{H}$ NOESY NMR with a mixing time of 1.5 seconds. This procedure was repeated with $0.120 \mathrm{mmol}$ (5 equiv.), $0.240 \mathrm{mmol}$ (10 equiv.), and $0.480 \mathrm{mmol}$ (20 equiv.) of butadiene. Example NOESY data is given in Figure S15. Intensities were obtained from integration of cross-peaks between

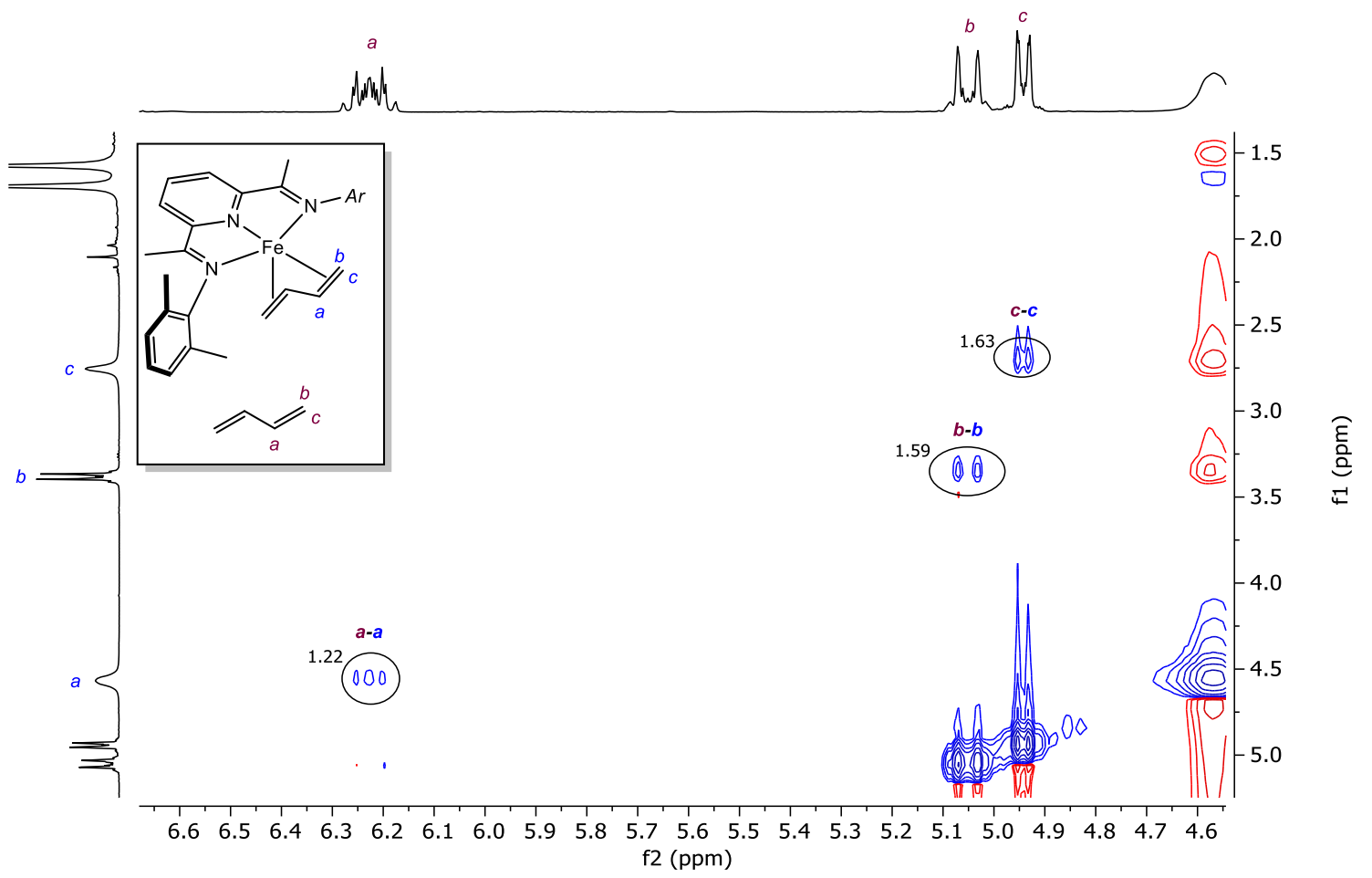

Figure S15. Truncated ${ }^{1} \mathrm{H}-{ }^{1} \mathrm{H}$ NOESY NMR $\left(400 \mathrm{MHz}, \mathrm{C}_{6} \mathrm{D}_{6}, 25^{\circ} \mathrm{C}\right)$ spectra of the reaction of (MePDI)Fe(s-trans $\mathrm{C}_{4} \mathrm{H}_{6}$ ) with 1 equivalent of butadiene. Assignments of cross-peaks and integrations are given. 
free and iron-bound butadiene. Values for $k_{o b s}$ were then obtained using Perrin's equations ${ }^{12}$ and intensities from each concentration.

\section{Experiments Relevant to Oxidative Cyclization}

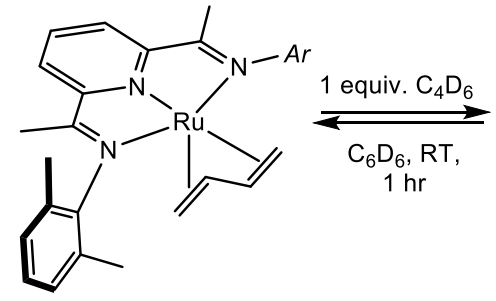

(MePDI)Ru(s-trans $\mathrm{C}_{4} \mathrm{H}_{6}$ )

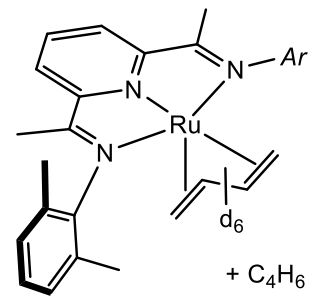

$10 \%$ D incorporation

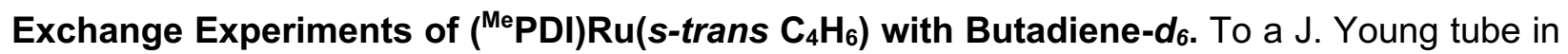
the glove box was added a solution of $0.012 \mathrm{~g}(0.022 \mathrm{mmol})$ of ( $\left.{ }^{\mathrm{Me}} \mathrm{PDI}\right) \mathbf{R u}\left(\mathbf{s}\right.$-trans $\left.\mathbf{C}_{4} \mathrm{H}_{6}\right)$ in 0.600 $\mathrm{mL}$ of $\mathrm{C}_{6} \mathrm{D}_{6}$. The tube was capped and the contents frozen in liquid nitrogen after which 0.022 mmol ( 1 equiv.) of butadiene- $d_{6}$ was added using a calibrated gas bulb. The contents of the tube were thawed in a room temperature water bath, mixed by inversion continuously for 1 hour, then analyzed by ${ }^{1} \mathrm{H}$ NMR spectroscopy. The presence of free protio-butadiene in the ${ }^{1} \mathrm{H}$ NMR spectrum indicated exchange of butadiene, which was quantified as conversion relative to the
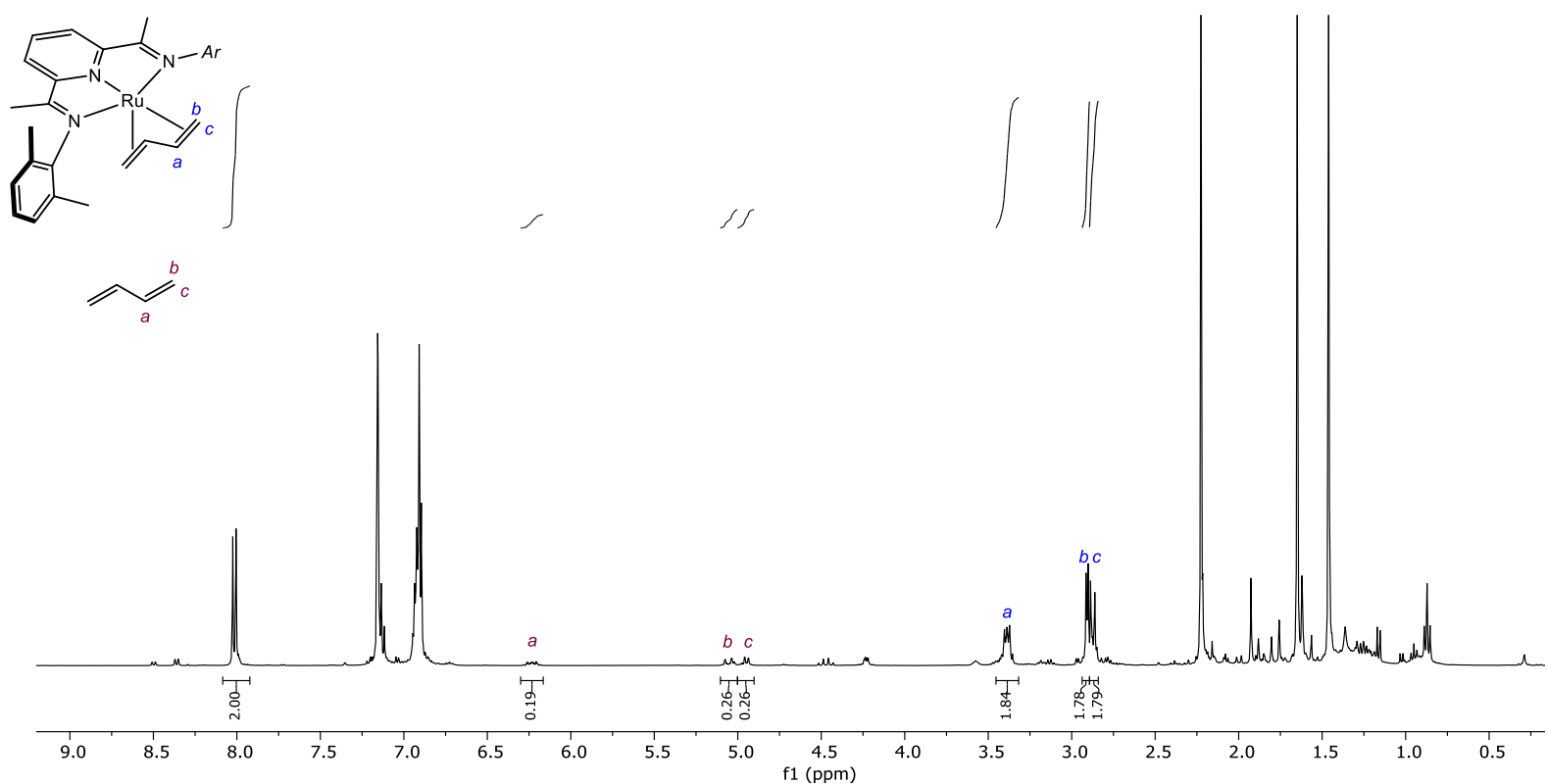

Figure S16. ${ }^{1} \mathrm{H}$ NMR $\left(400 \mathrm{MHz}, \mathrm{C}_{6} \mathrm{D}_{6}, 25^{\circ} \mathrm{C}\right)$ spectra of the reaction of (MePDI)Ru(s-trans $\left.\mathrm{C}_{4} \mathrm{H}_{6}\right)$ with stoichiometric butadiene- $d_{6}$ after 1 hour of reaction time. Assignment of the protio-butadiene moieties is given. 
signals corresponding to natural abundance butadiene bound to the Ru center. Analysis of liberated butadiene indicated that only $10 \%$ of the butadiene had exchanged after 1 hour. The ${ }^{1} \mathrm{H}$ NMR spectrum is presented in Figure S16.

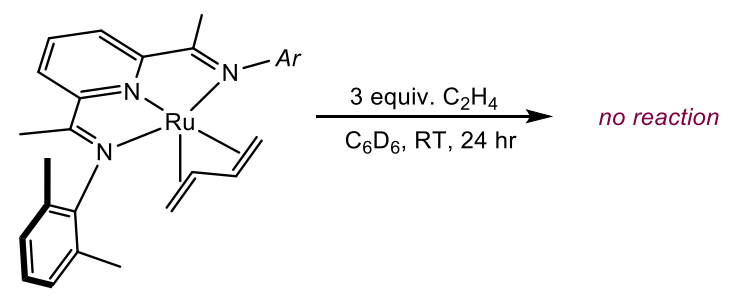

Stoichiometric Reactivity of of $\left({ }^{\mathrm{Me}} \mathrm{PDI}\right) \mathrm{Ru}\left(\mathrm{s}\right.$-trans $\left.\mathrm{C}_{4} \mathrm{H}_{6}\right)$ with Ethylene. To a J. Young tube in the glove box was added a solution of $0.010 \mathrm{~g}(0.0190 \mathrm{mmol})$ of ( $\left.{ }^{\mathrm{Me}} \mathrm{PDI}\right) \mathbf{R u}\left(\mathbf{s}-\right.$ trans $\left.\mathbf{C}_{4} \mathbf{H}_{6}\right)$ in 0.600 $\mathrm{mL} \mathrm{C}_{6} \mathrm{D}_{6}$. The tube was capped and frozen in liquid nitrogen, after which $0.057 \mathrm{mmol}$ (3 equiv.) of ethylene was added using a calibrated gas bulb. The contents of the tube were thawed in a room temperature water bath and mixed by inversion continuously for 24 hours. After 24 hours, the reaction was analyzed by ${ }^{1} \mathrm{H}$ NMR spectroscopy and no evidence for the formation of 2 was obtained. The identity of the Ru was determined to be unreacted ( $\left.{ }^{M e} \mathrm{PDI}\right) \mathrm{Ru}\left(\mathrm{s}-\mathrm{trans} \mathrm{C}_{4} \mathrm{H}_{6}\right)$. The 1H NMR spectrum is presented in Figure S17.

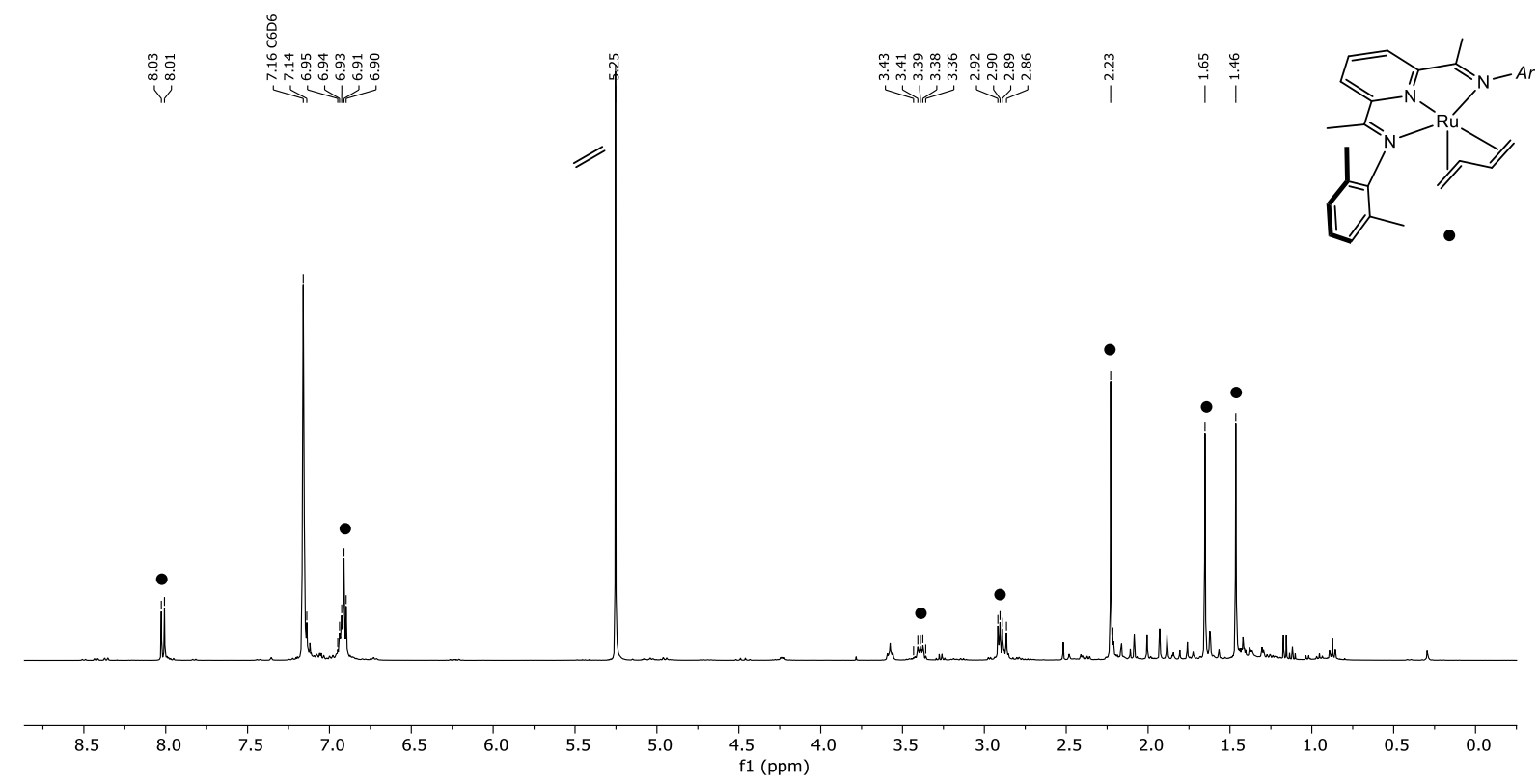

Figure S17. ${ }^{1} \mathrm{H}$ NMR (400 MHz, $\left.\mathrm{C}_{6} \mathrm{D}_{6}, 25^{\circ} \mathrm{C}\right)$ spectra of the reaction of (MePDI)Ru(s-trans $\left.\mathbf{C}_{4} \mathrm{H}_{6}\right)$ with superstoichiometric ethylene after 24 hours of reaction time. 


\section{Experiments Relevant to Reductive Elimination}

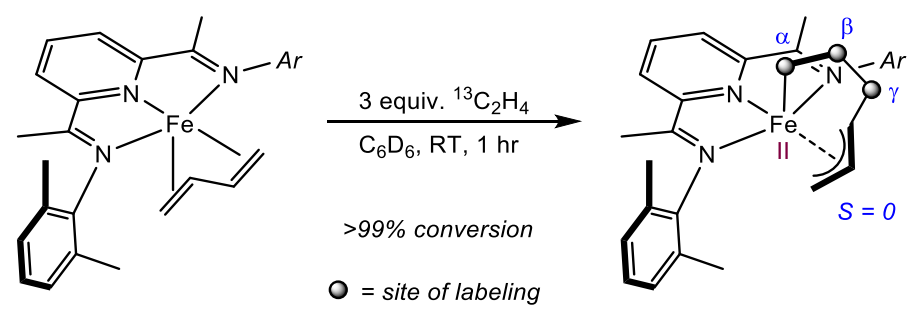

Stoichiometric Reactivity of (MePDI)Fe(s-trans $\mathrm{C}_{4} \mathrm{H}_{6}$ ) with ${ }^{13} \mathrm{C}$-Labeled Ethylene. To a J. Young tube in the glove box was added a solution of $0.015 \mathrm{mg}(0.0313 \mathrm{mmol})$ of (MePDI)Fe(strans $\mathrm{C}_{4} \mathrm{H}_{6}$ ) in $0.500 \mathrm{~mL} \mathrm{C}_{6} \mathrm{D}_{6}$. The tube was capped and the contents frozen in liquid nitrogen, after which $0.0939 \mathrm{mmol}$ ( 3 equiv) of ${ }^{13} \mathrm{C}$-labeled ethylene was added with a calibrated gas bulb. The solution was thawed in a room temperature water bath and mixed by inversion for one hour, after which the reaction was analyzed by ${ }^{1} \mathrm{H}$ and ${ }^{13} \mathrm{C}\left\{{ }^{1} \mathrm{H}\right\}$ NMR spectroscopy. The ${ }^{1} \mathrm{H}$ and ${ }^{13} \mathrm{C}\left\{{ }^{1} \mathrm{H}\right\}$ NMR spectra are presented in Figure S18A and S18B, respectively.

The volatiles of the reaction were isolated from the reaction mixture by vacuum transfer into a $\mathrm{J}$. Young tube containing $0.010 \mathrm{~mL}(0.0718 \mathrm{mmol})$ of mesitylene. The tube containing the reaction mixture was placed in a room temperature water bath during the vacuum transfer. The volatiles of the reaction were then analyzed by ${ }^{1} \mathrm{H}$ and ${ }^{13} \mathrm{C}\left\{{ }^{1} \mathrm{H}\right\}$ NMR and indicated free, labeled vinylcyclobutane in $21 \%$ yield. The ${ }^{1} \mathrm{H}$ and ${ }^{13} \mathrm{C}\left\{{ }^{1} \mathrm{H}\right\}$ NMR spectra are presented in Figure S18C and S18D, respectively. 


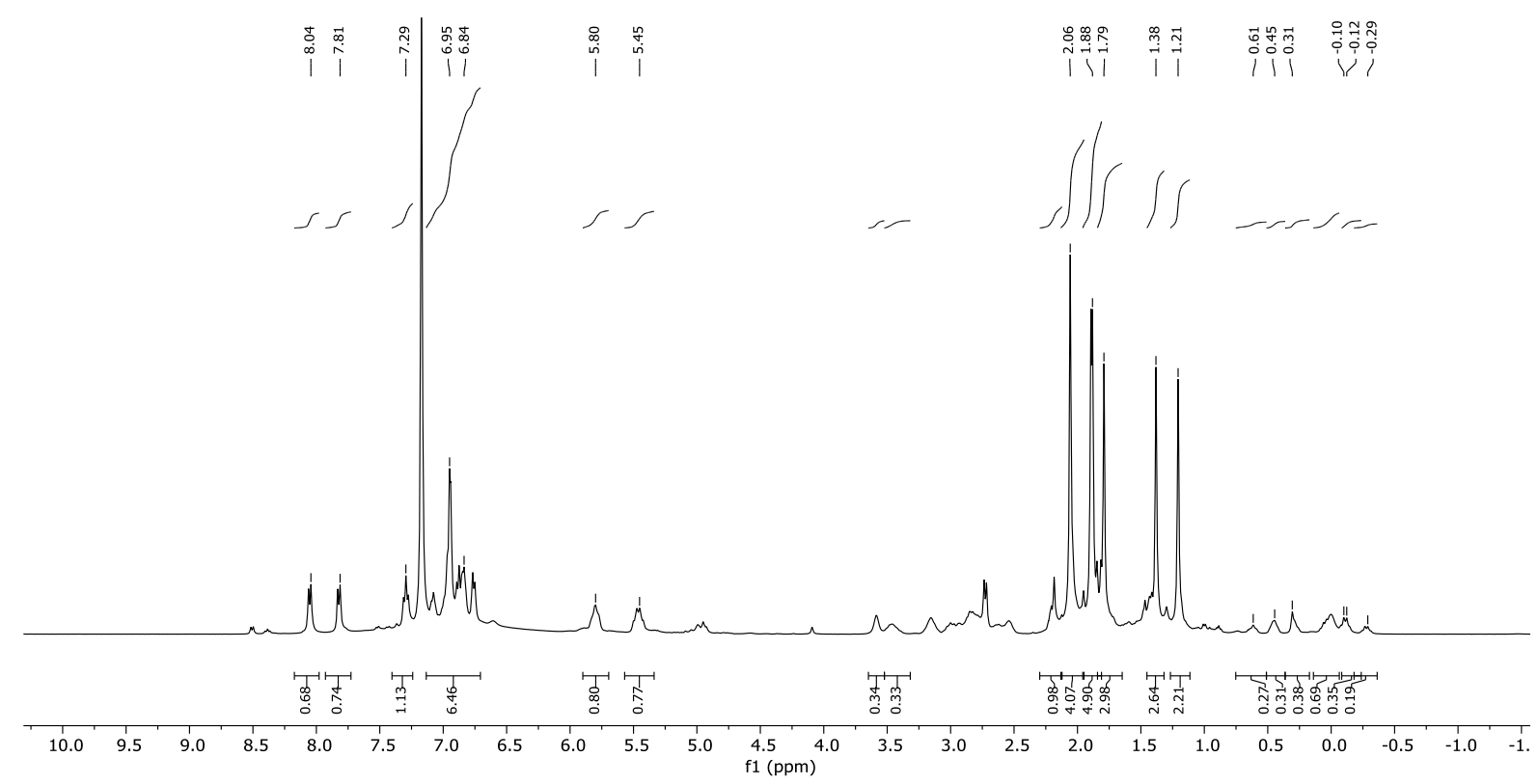

Figure S18A. ${ }^{1} \mathrm{H}$ NMR $\left(400 \mathrm{MHz}, \mathrm{C}_{6} \mathrm{D}_{6}, 25^{\circ} \mathrm{C}\right)$ spectrum of the reaction of (MepDI)Fe(s-trans $\left.\mathrm{C}_{4} \mathrm{H}_{6}\right)$ with superstoichiometric ${ }^{13} \mathrm{C}$-labeled ethylene.

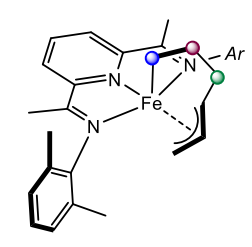

$$
\begin{aligned}
& 0 \\
& 00 \\
& 0 \\
& 0 \\
& 0 \\
& -1 \\
& 1
\end{aligned}
$$

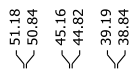

$\circ$
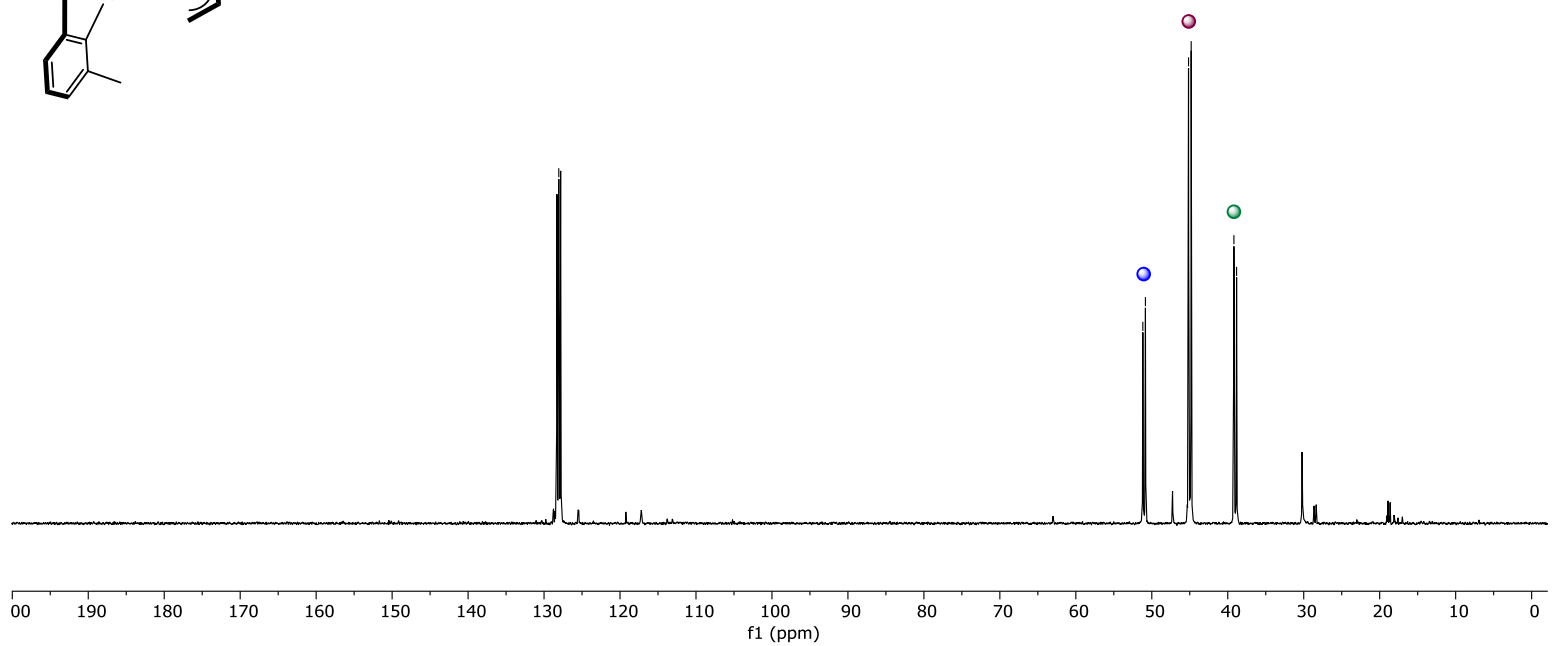

Figure S18B. ${ }^{13} \mathrm{C}\left\{{ }^{1} \mathrm{H}\right\} \mathrm{NMR}\left(101 \mathrm{MHz}, \mathrm{C}_{6} \mathrm{D}_{6}, 25^{\circ} \mathrm{C}\right)$ spectrum of the reaction of (MePDI)Fe(s-trans $\left.\mathrm{C}_{4} \mathrm{H}_{6}\right)$ with superstoichiometric ${ }^{13} \mathrm{C}$-labeled ethylene. Assignment of the signals corresponding to the ${ }^{13} \mathrm{C}$-labeled carbons in the metallacyclic fragment are given. 


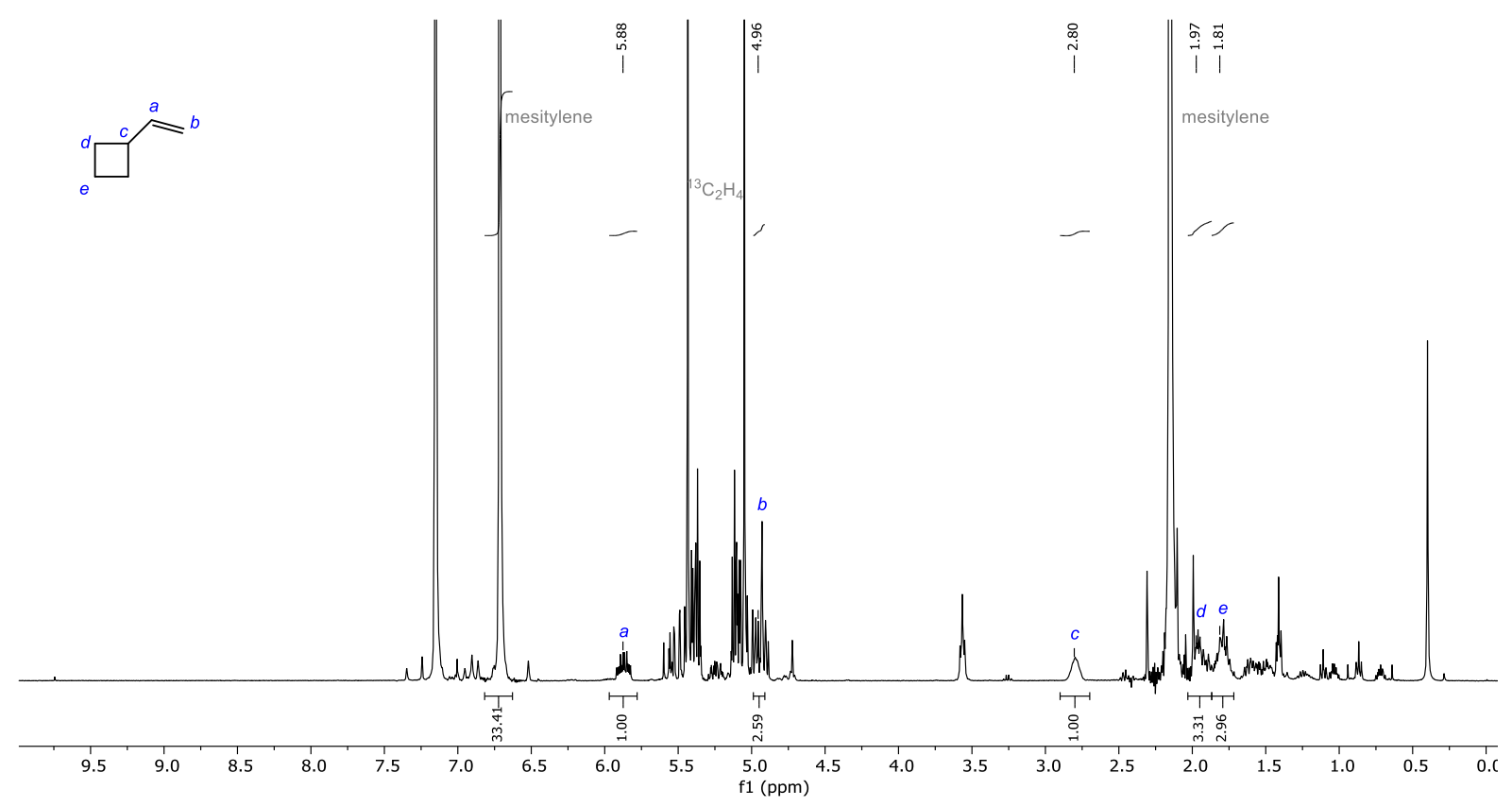

Figure S18C. ${ }^{1} \mathrm{H}$ NMR $\left(400 \mathrm{MHz}, \mathrm{C}_{6} \mathrm{D}_{6}, 25^{\circ} \mathrm{C}\right)$ spectrum of the volatiles of the reaction of (MePDI)Fe(s-trans $\mathrm{C}_{4} \mathrm{H}_{6}$ ) with superstoichiometric ${ }^{13} \mathrm{C}$-labeled ethylene. Peaks corresponding to vinylcyclobutane are annotated.

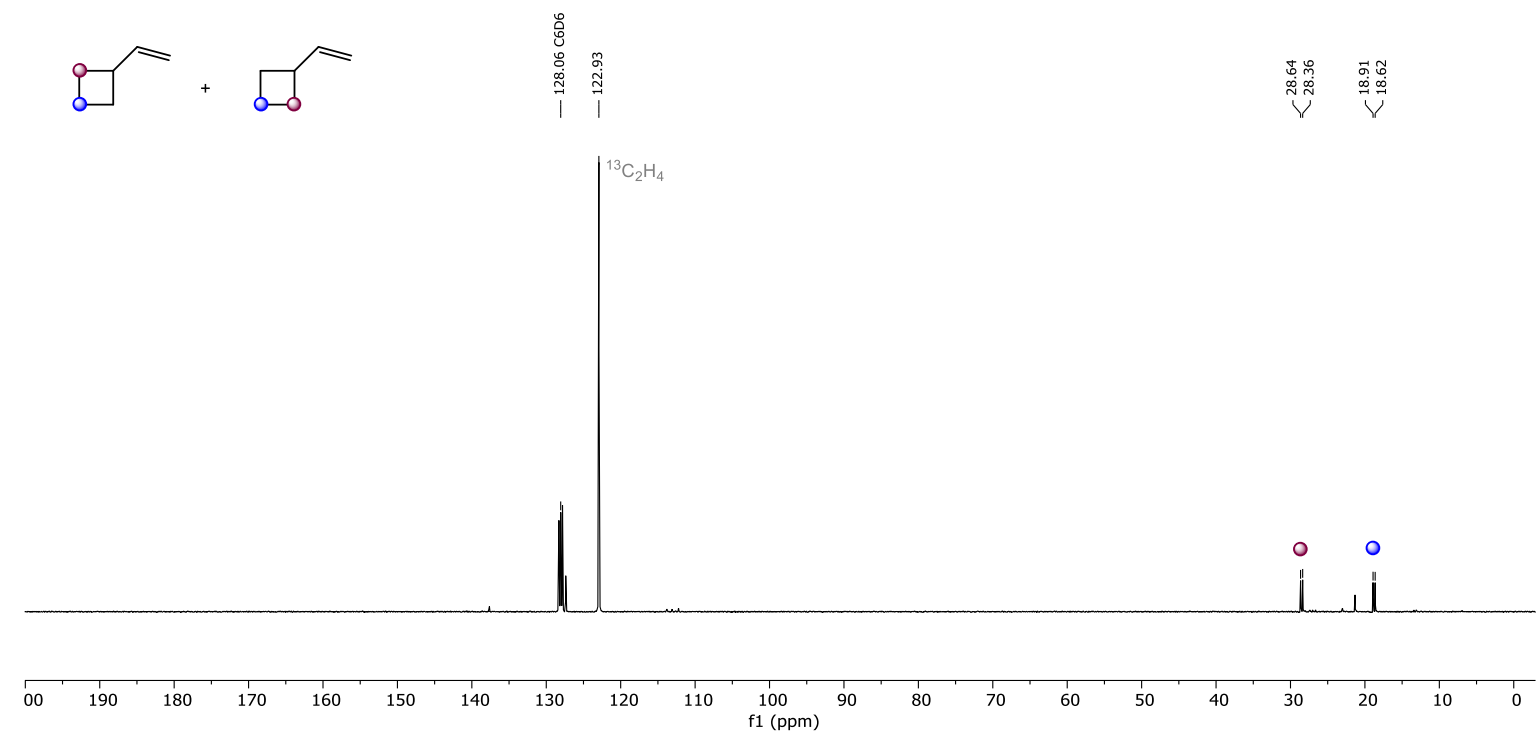

Figure S18D. ${ }^{13} \mathrm{C}\left\{{ }^{1} \mathrm{H}\right\}$ NMR $\left(101 \mathrm{MHz}, \mathrm{C}_{6} \mathrm{D}_{6}, 25^{\circ} \mathrm{C}\right)$ spectrum of the volatiles from the reaction of (MepDI)Fe(strans $\mathrm{C}_{4} \mathrm{H}_{6}$ ) with superstoichiometric ${ }^{13} \mathrm{C}$-labeled ethylene. Assignment of the signals corresponding to ${ }^{13} \mathrm{C}$-labeled carbons in vinylcyclobutane are given. 

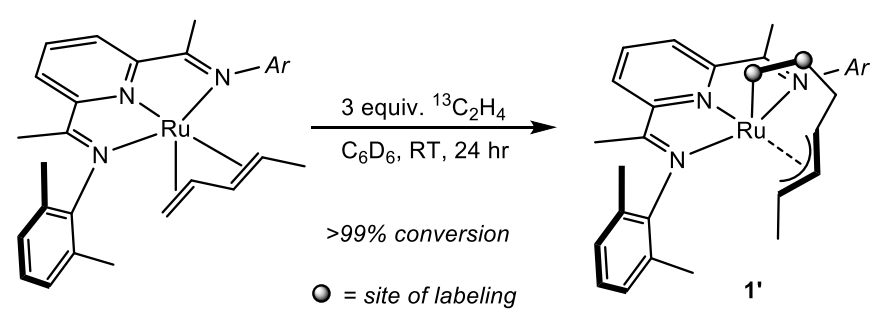

Stoichiometric Reactivity of ( ${ }^{\text {MePDI}}$ Ru(s-trans E-piperylene) with ${ }^{13} \mathrm{C}$-Labeled Ethylene. To a J. Young tube in the glove box was added a solution of $0.013 \mathrm{mg}(0.0241 \mathrm{mmol})$ of ( $\left.{ }^{\mathrm{Me}} \mathrm{PDI}\right) \mathrm{Ru}(\mathrm{s}-$ trans $\mathrm{C}_{4} \mathrm{H}_{6}$ ) in $0.600 \mathrm{~mL} \mathrm{C}_{6} \mathrm{D}_{6}$. The tube was capped and the contents frozen in liquid nitrogen, after which $0.0724 \mathrm{mmol}$ ( 3 equiv,) of ${ }^{13} \mathrm{C}$-labeled ethylene were added with a calibrated gas bulb. The solution was thawed in a room temperature water bath, mixed by inversion and analyzed by ${ }^{1} \mathrm{H}$ and ${ }^{13} \mathrm{C}\left\{{ }^{1} \mathrm{H}\right\}$ NMR immediately. The tube was then mixed by inversion at room temperature for 24 hours, with timepoints taken by ${ }^{1} \mathrm{H}$ and ${ }^{13} \mathrm{C}\left\{{ }^{1} \mathrm{H}\right\}$ NMR after 2 hours and 24 hours of reaction time. The compiled ${ }^{1} \mathrm{H}$ and ${ }^{13} \mathrm{C}\left\{{ }^{1} \mathrm{H}\right\}$ NMR spectra are presented in Figure S19A and S19B, respectively. After 24 hours, the volatiles of the reaction mixture were removed by vacuum distillation into a J. Young tube, and the residue was reconstituted in $0.600 \mathrm{~mL}$ of $\mathrm{C}_{6} \mathrm{D}_{6}$ in the glove box. Characterization of the volatiles by ${ }^{1} \mathrm{H}$ NMR provided no evidence for the formation of propenylcyclobutane (Figure S19C). Further, characterization of the nonvolatile product in the residue by ${ }^{1} \mathrm{H}$ and ${ }^{13} \mathrm{C}\left\{{ }^{1} \mathrm{H}\right\}$ NMR indicated clean and quantitative formation of a product assigned as 1' (Figure S19D and S19E). 


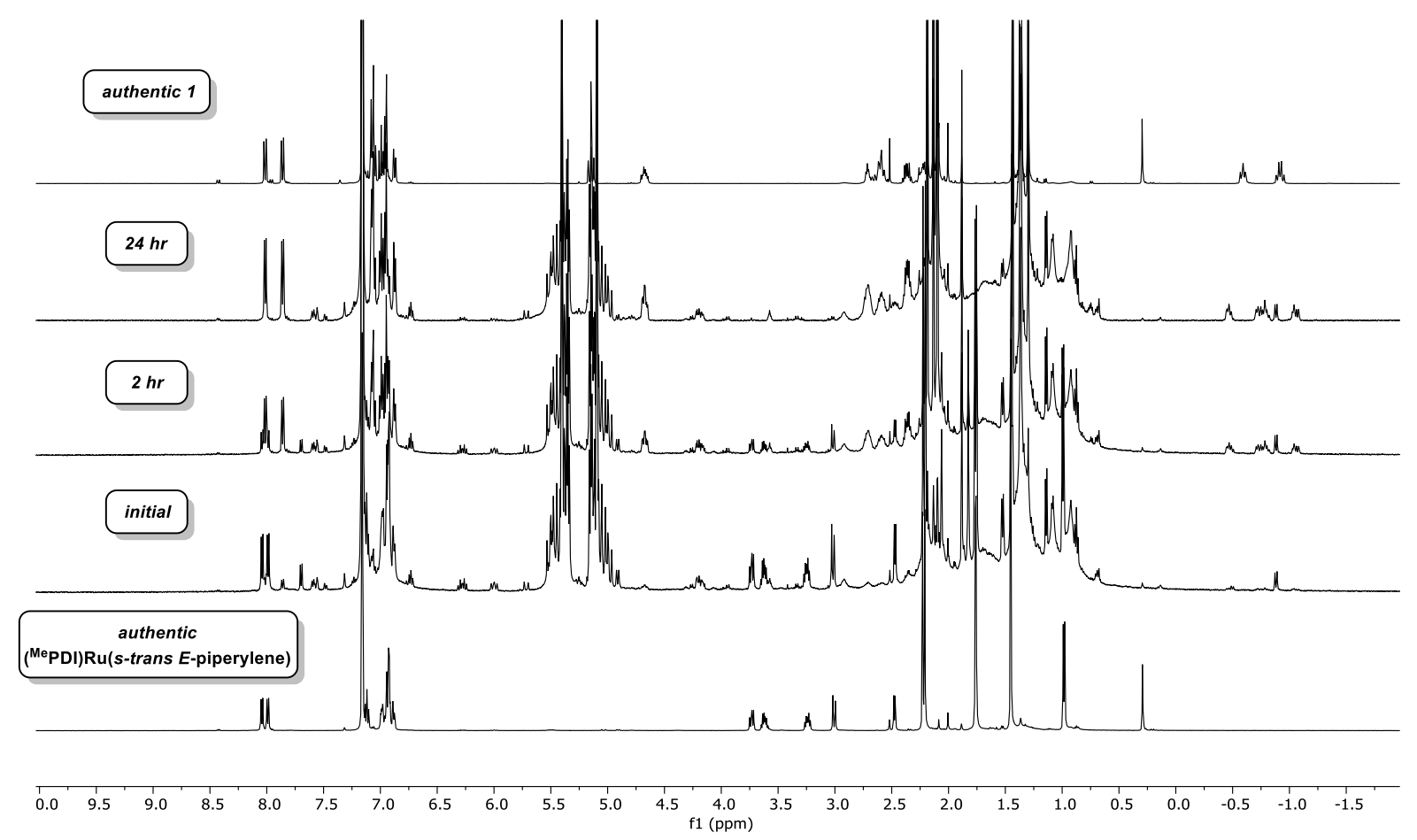

Figure S19A. Stacked ${ }^{1} \mathrm{H}$ NMR $\left(500 \mathrm{MHz}, \mathrm{C}_{6} \mathrm{D}_{6}, 25^{\circ} \mathrm{C}\right)$ spectra of the reaction of (MePDI)Ru(s-trans E-piperylene) with superstoichiometric ${ }^{13} \mathrm{C}$-labeled ethylene. Authentic spectra of (MePDI)Ru(s-trans E-piperylene) (bottom) and 1 (top) are provided for comparison
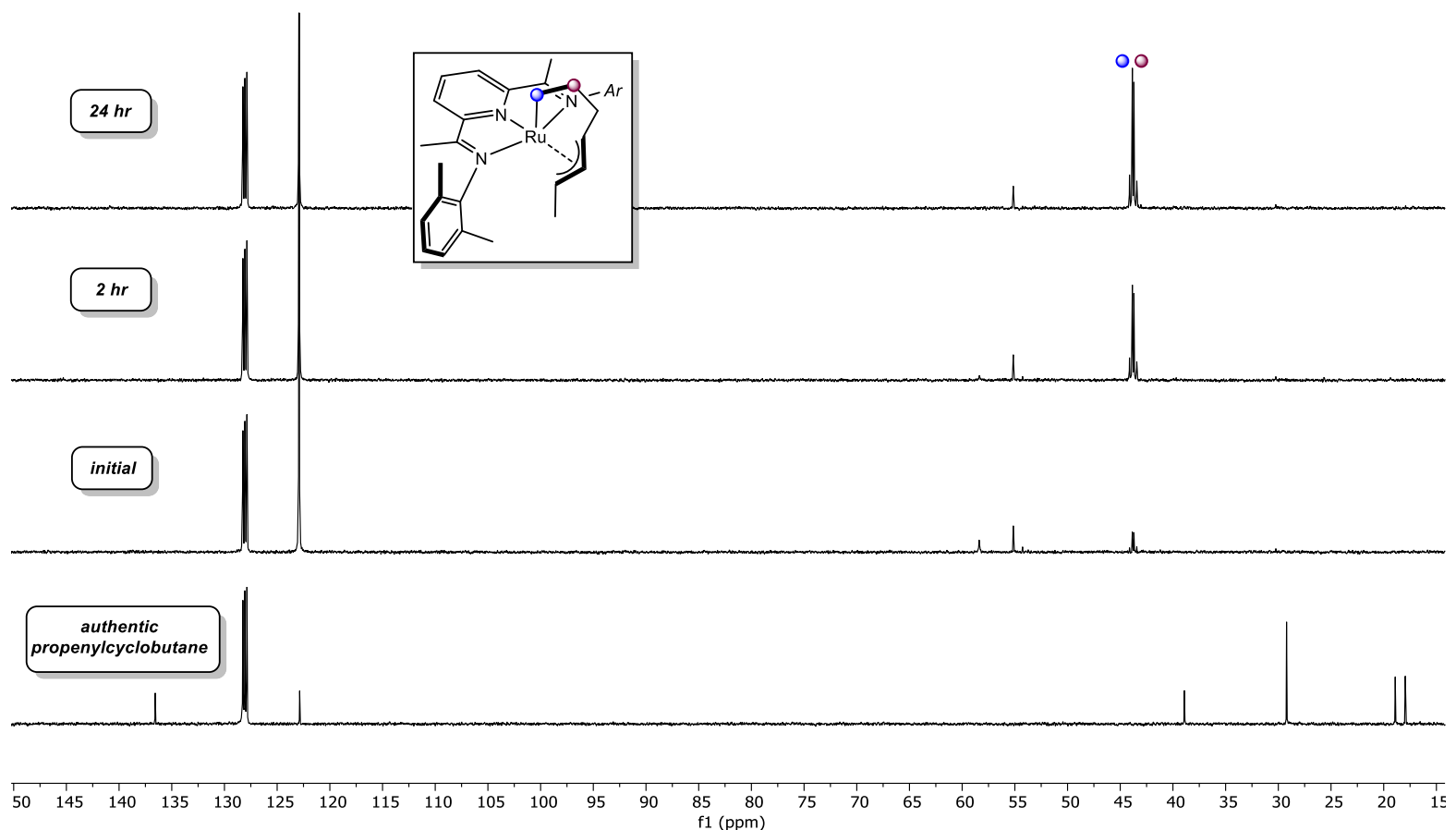

Figure S19B. Stacked ${ }^{13} \mathrm{C}\left\{{ }^{1} \mathrm{H}\right\}$ NMR $\left(126 \mathrm{MHz}, \mathrm{C}_{6} \mathrm{D}_{6}, 25^{\circ} \mathrm{C}\right)$ spectrum of the reaction of (MePDI)Ru(s-trans Epiperylene) with superstoichiometric ${ }^{13} \mathrm{C}$-labeled ethylene. An authentic spectrum of propenylcyclobutane is provided for comparison. Assignment of the ${ }^{13} \mathrm{C}$-labeled positions of 1 ' is shown. 


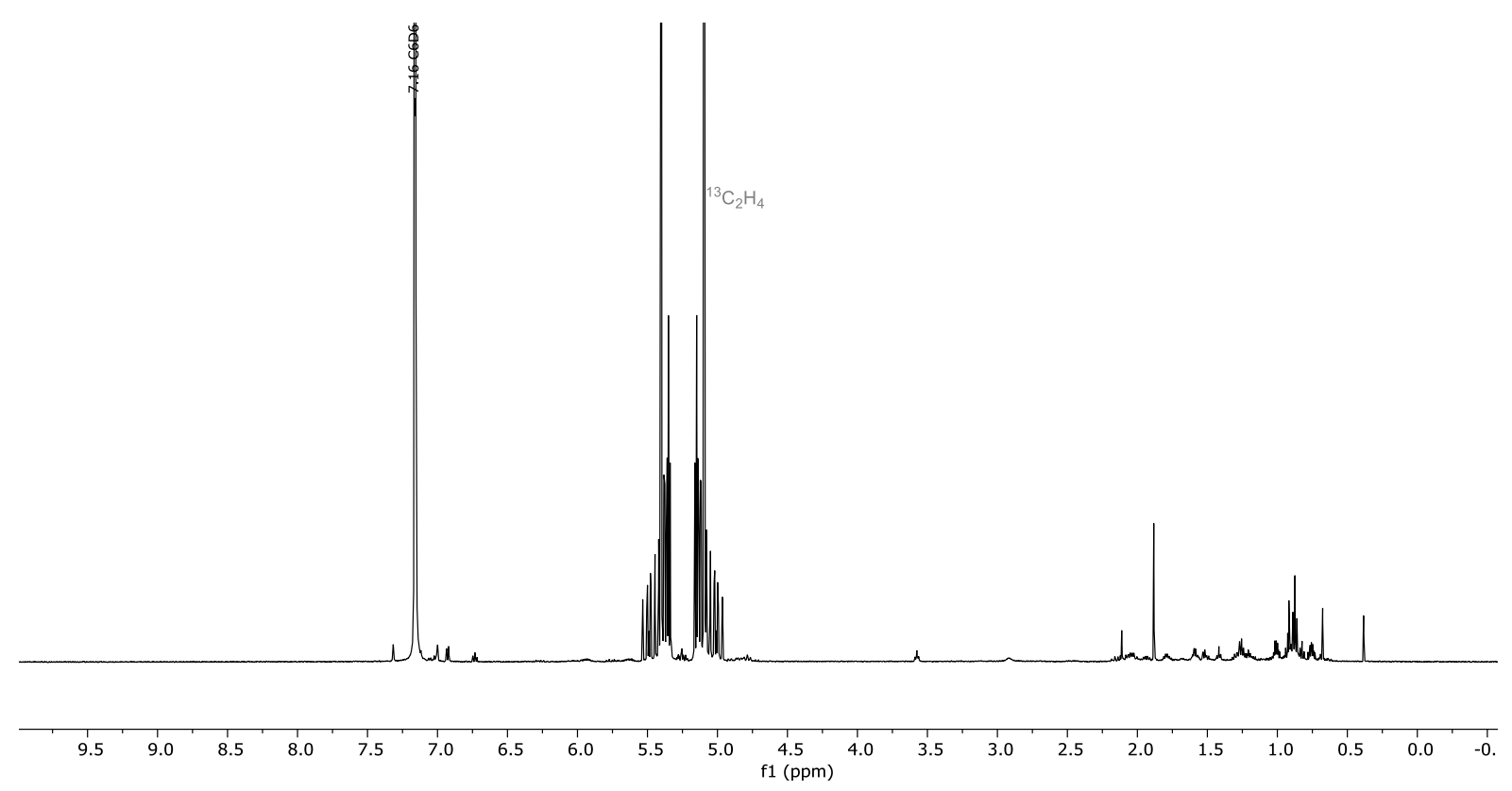

Figure S19C. ${ }^{1} \mathrm{H}$ NMR $\left(500 \mathrm{MHz}, \mathrm{C}_{6} \mathrm{D}_{6}, 25^{\circ} \mathrm{C}\right)$ spectrum of the volatiles from the reaction of (MePDI)Ru(s-trans Epiperylene) with superstoichiometric ${ }^{13} \mathrm{C}$-labeled ethylene.

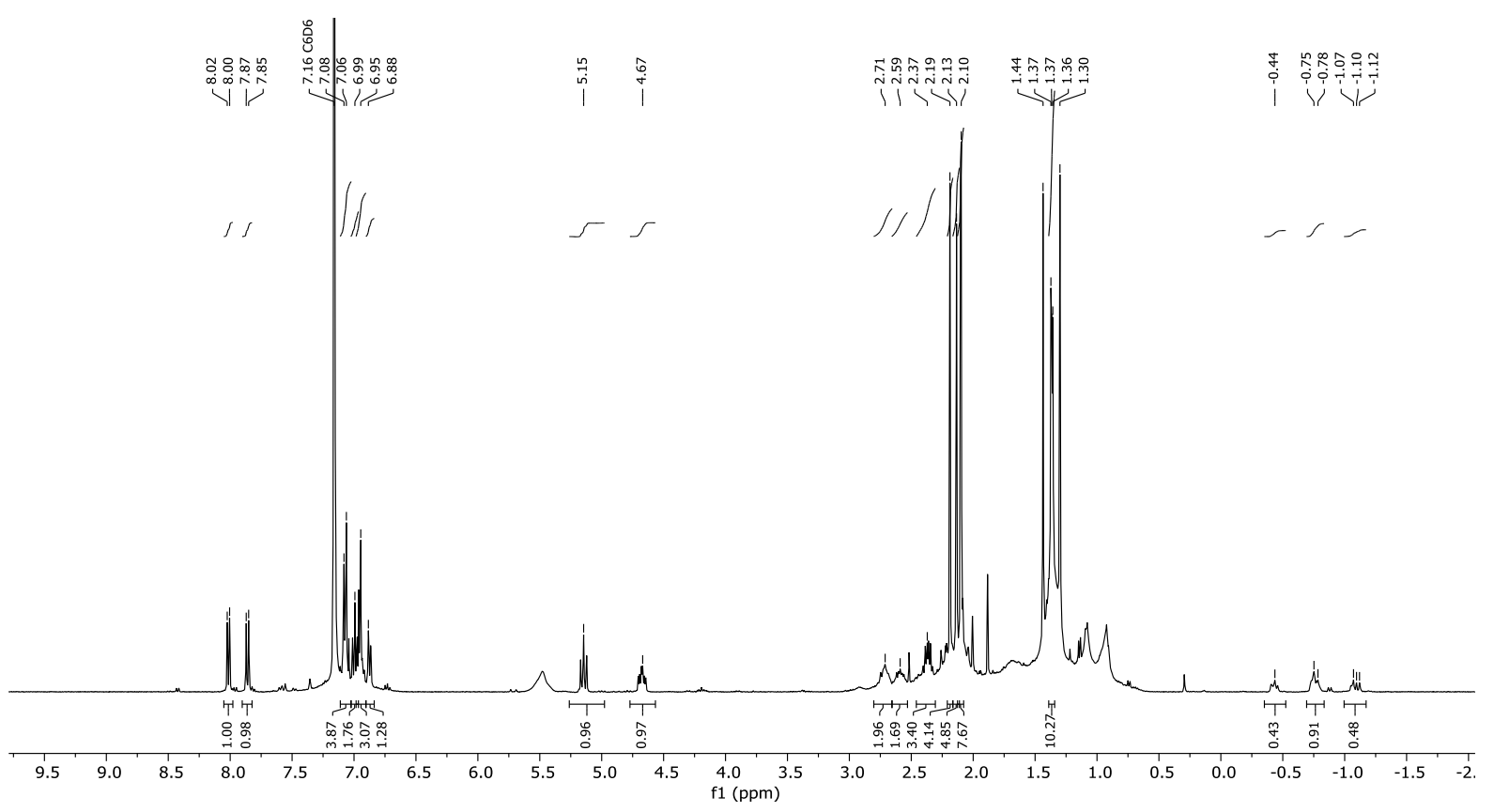

Figure S19D. ${ }^{1} \mathrm{H}$ NMR $\left(500 \mathrm{MHz}, \mathrm{C}_{6} \mathrm{D}_{6}, 25^{\circ} \mathrm{C}\right)$ spectrum of the nonvolatile product (1') of the reaction of (MePDI)Ru(s-trans E-piperylene) with superstoichiometric ${ }^{13} \mathrm{C}$-labeled ethylene. 


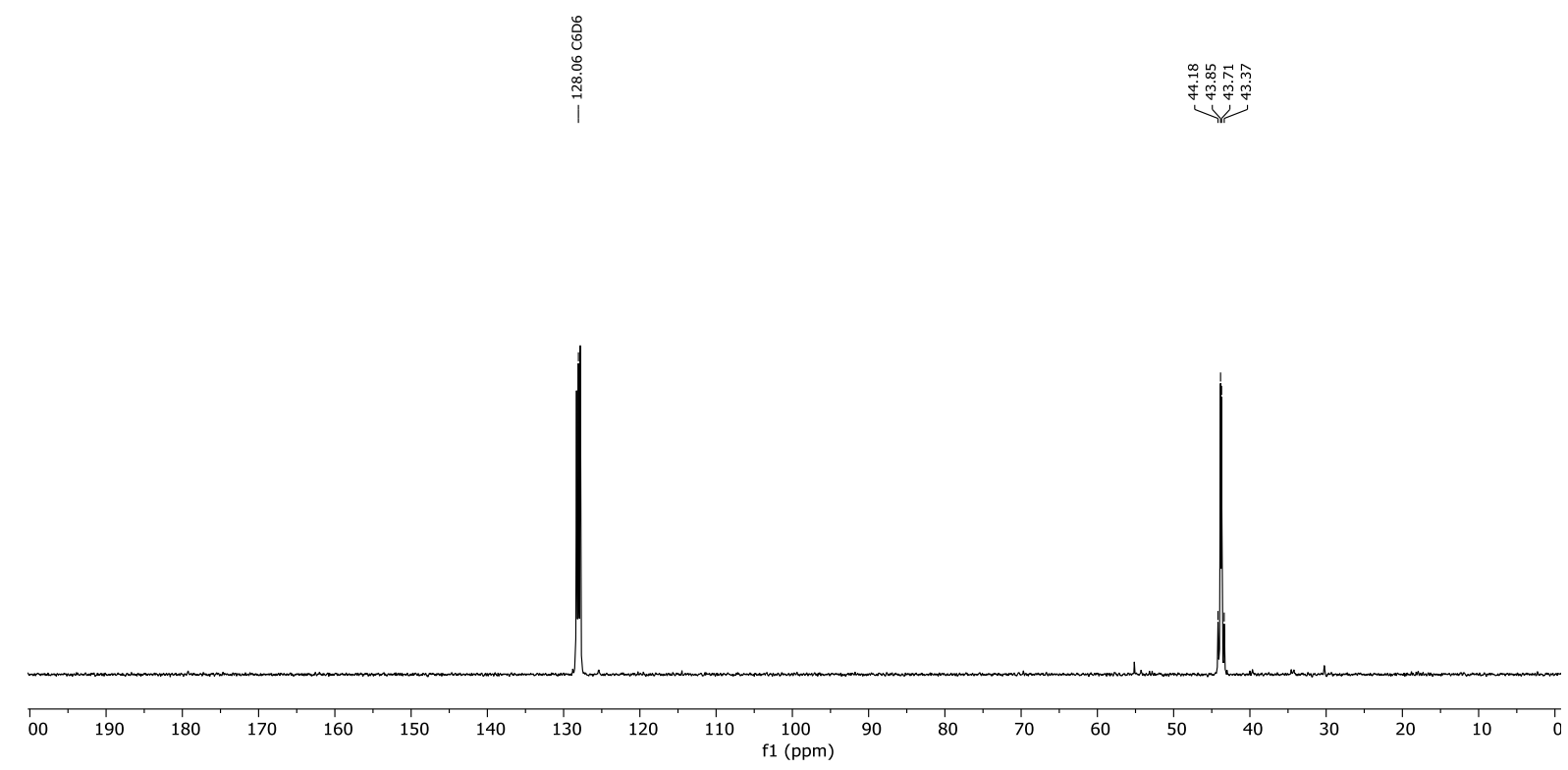

Figure S19E. ${ }^{1} \mathrm{H}$ NMR $\left(500 \mathrm{MHz}, \mathrm{C}_{6} \mathrm{D}_{6}, 25^{\circ} \mathrm{C}\right)$ spectrum of the nonvolatile product (1') of the reaction of ( ${ }^{\text {MePDI}) R u(s-t r a n s ~ E-p i p e r y l e n e) ~ w i t h ~ s u p e r s t o i c h i o m e t r i c ~}{ }^{13} \mathrm{C}$-labeled ethylene. 


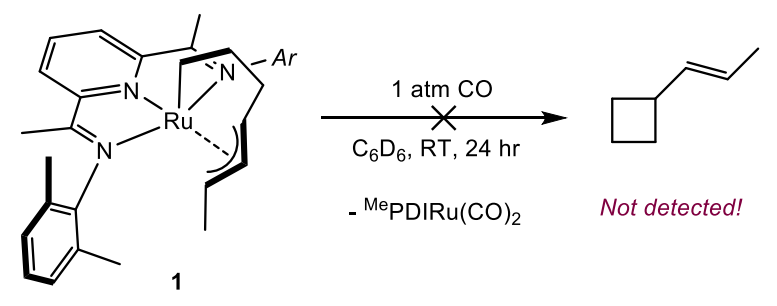

Stoichiometric Reactivity of 1 with CO. To a J. Young tube in the glove box was added a solution of $0.014 \mathrm{mg}(0.0249 \mathrm{mmol})$ of $1 \mathrm{in} 0.600 \mathrm{~mL} \mathrm{C}_{6} \mathrm{D}_{6}$. The tube was capped and the contents frozen in liquid nitrogen after which 1 atm of $\mathrm{CO}$ was added on a high vacuum line. The solution was thawed in a room temperature water bath and mixed by inversion for 24 hours. After 24 hours, a ${ }^{1} \mathrm{H}$ NMR was taken of the reaction mixture and indicated the formation of $\left({ }^{\mathrm{Me} P D I}\right) \mathrm{Ru}(\mathrm{CO})_{2}$ and an unidentified, $C_{2 v}$ symmetric product. No free propenylcyclobutane was identified in the crude reaction mixture (Figure S20A). The volatiles of the reaction were isolated from the reaction mixture by vacuum transfer into a J. Young tube and analyzed by ${ }^{1} \mathrm{H}$ NMR spectroscopy. The ${ }^{1} \mathrm{H}$ NMR spectrum did not contain free propenylcyclobutane (Figure S20B). Taken together, it appears that the addition of $\mathrm{CO}$ either did not induce reductive elimination or that $\mathrm{CO}$ cannot liberate formed propenylcyclobutane from being bound to the ruthenium center. 




Figure S20A. ${ }^{1} \mathrm{H}$ NMR $\left(400 \mathrm{MHz}, \mathrm{C}_{6} \mathrm{D}_{6}, 25^{\circ} \mathrm{C}\right)$ spectrum of the reaction of 1 with superstoichiometric CO. Annotations for ( $\left.{ }^{\mathrm{Me}} \mathrm{PDI}\right) \mathrm{Ru}(\mathrm{CO})_{2}$ and an unidentified, $\mathrm{C}_{2 v}$ symmetric product are given.

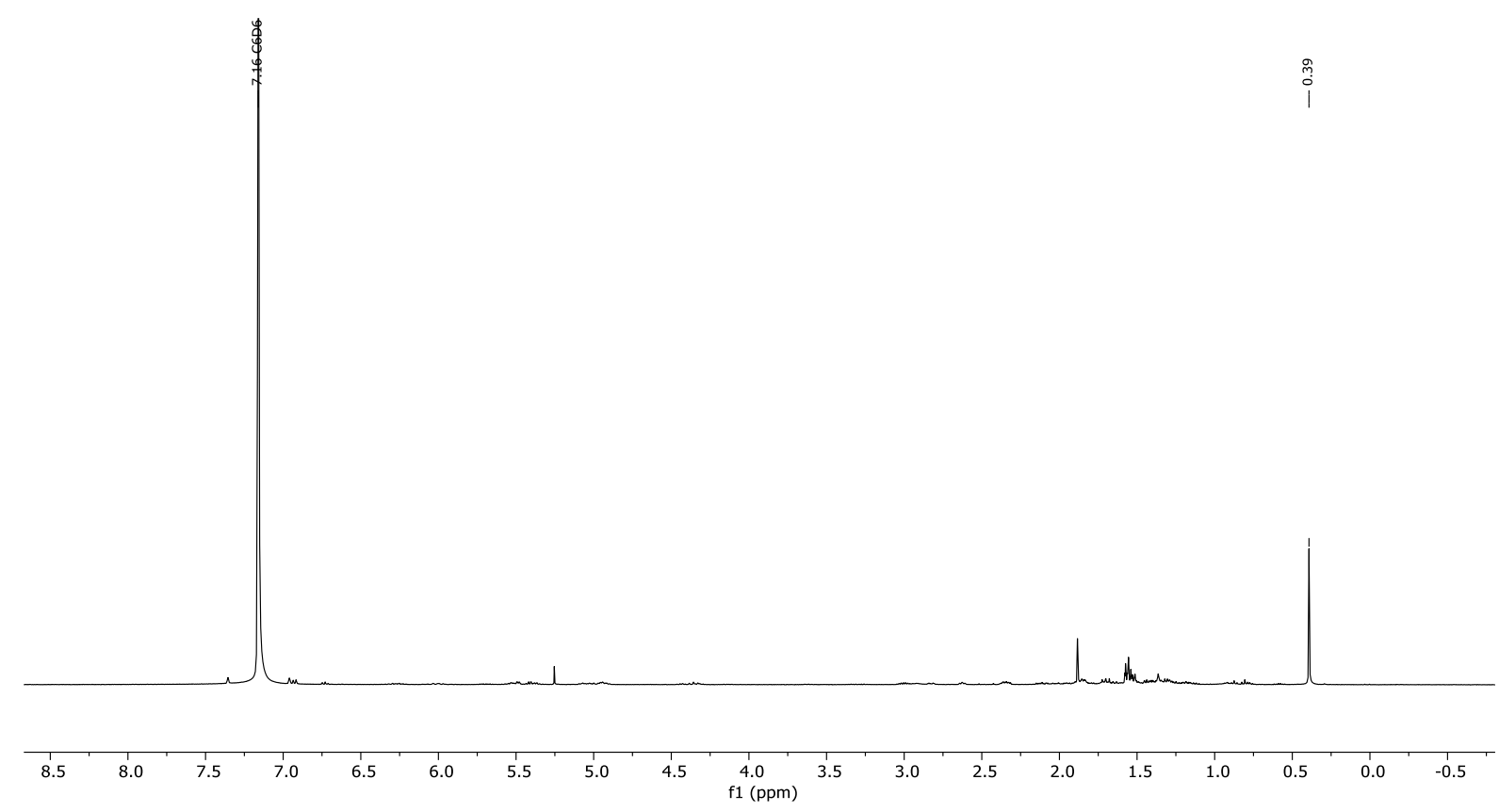

Figure S20B. ${ }^{1} \mathrm{H}$ NMR $\left(400 \mathrm{MHz}, \mathrm{C}_{6} \mathrm{D}_{6}, 25{ }^{\circ} \mathrm{C}\right)$ spectrum of the volatiles from the reaction of 1 with superstoichiometric $\mathrm{CO}$. 


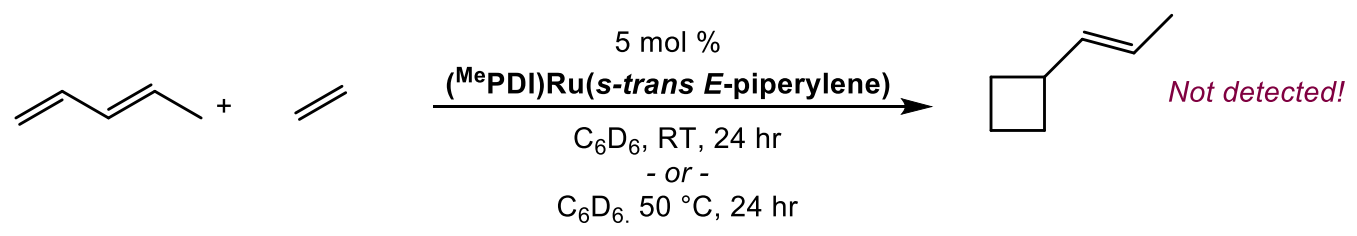

Catalytic Competence of ( $\left.{ }^{\mathrm{Me}} \mathrm{PDI}\right) \mathrm{Ru}($ s-trans E-piperylene) in [2+2] Cycloaddition. A J. Young tube was prepared as described in General Procedure B: [2+2] Cycloaddition of Piperylene and Ethylene. After 24 hours of reaction time, the reaction was analyzed by ${ }^{1} \mathrm{H}$ NMR spectroscopy and no formation of propenylcyclobutane was detected (Figure S21A). The tube was then placed in an oil bath at $50{ }^{\circ} \mathrm{C}$ and heated without inversion for an additional 24 hours. Analysis of the reaction mixture by ${ }^{1} \mathrm{H}$ NMR spectroscopy also provided no evidence for the formation of propenylcyclobutane (Figure S21B). Identification of the Ru product in the reaction mixture was conducted by ${ }^{1} \mathrm{H}$ NMR spectroscopy of the $50{ }^{\circ} \mathrm{C}$ reaction; the compound present is consistent with 1 , resulting from oxidative cyclization of the precatalyst and ethylene. 

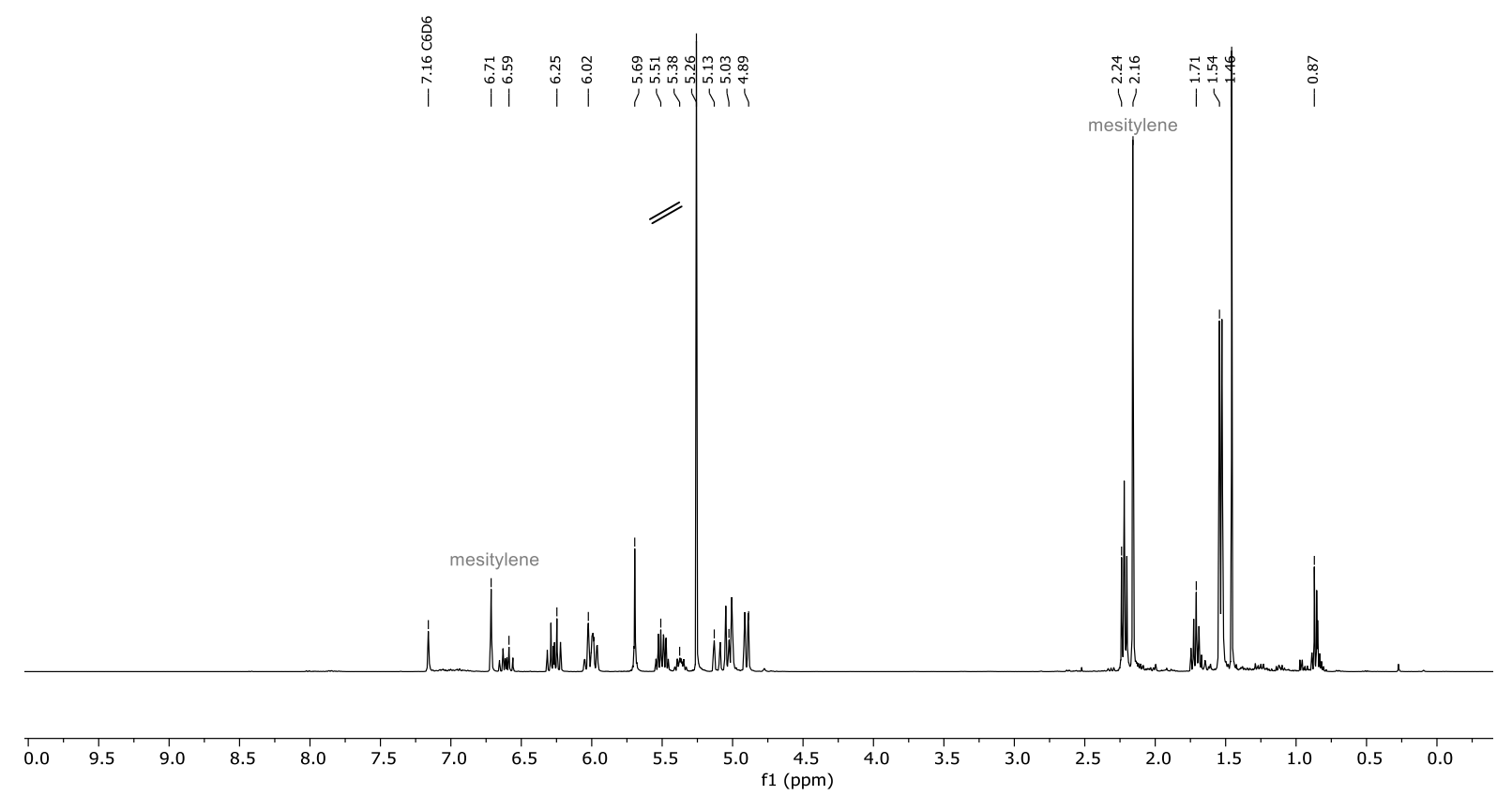

Figure S21A. ${ }^{1} \mathrm{H}$ NMR $\left(400 \mathrm{MHz}, \mathrm{C}_{6} \mathrm{D}_{6}, 25^{\circ} \mathrm{C}\right)$ spectrum of the [2+2] cycloaddition of piperylene and ethylene catalyzed by (MePDI)Ru(s-trans E-piperylene) after 24 hours of reaction time at room temperature.

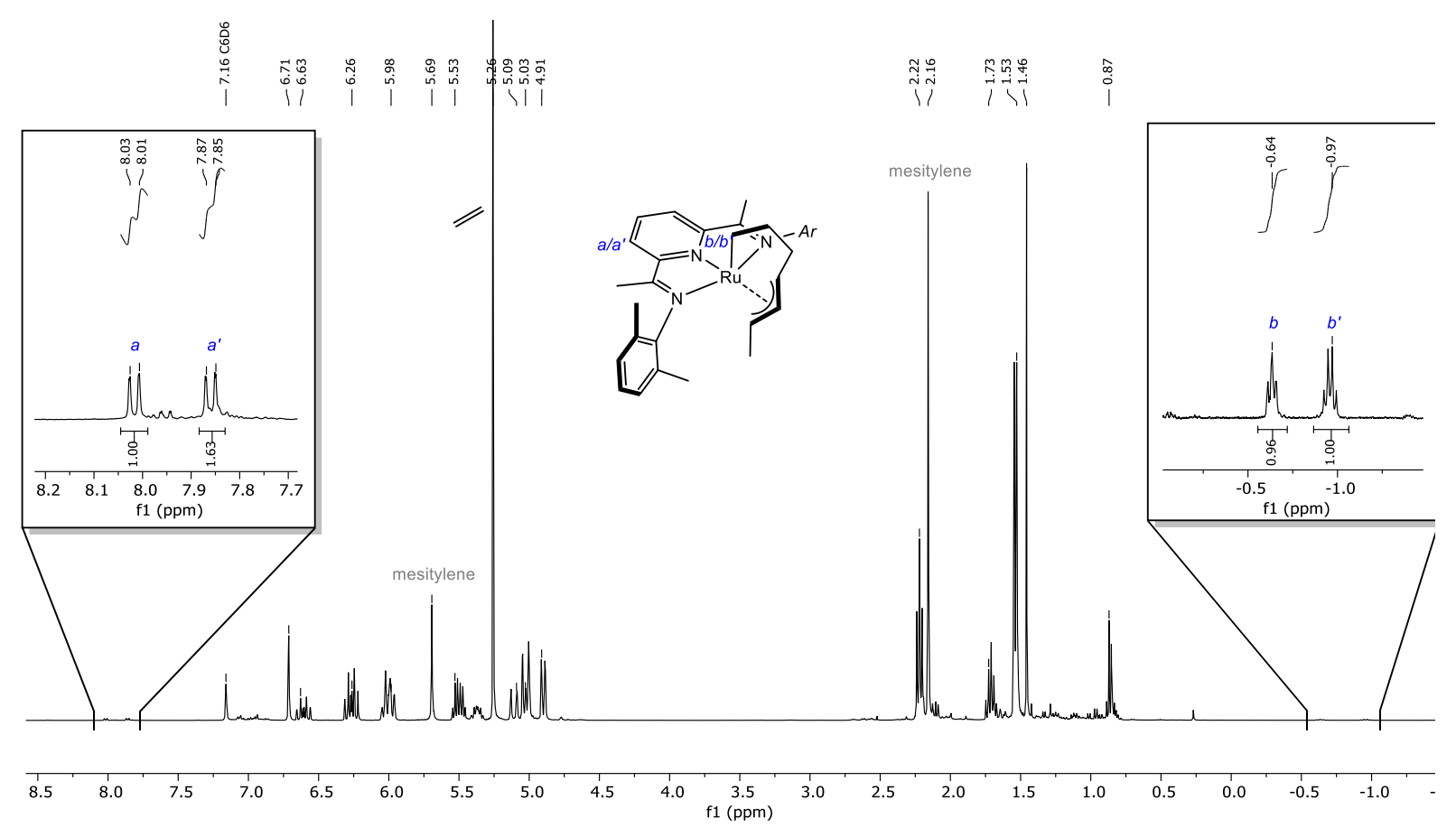

Figure S21B. ${ }^{1} \mathrm{H}$ NMR $\left(400 \mathrm{MHz}, \mathrm{C}_{6} \mathrm{D}_{6}, 25^{\circ} \mathrm{C}\right)$ spectrum of the [2+2] cycloaddition of piperylene and ethylene catalyzed by (MePDI)Ru(s-trans E-piperylene) after 24 hours of reaction time at $50{ }^{\circ} \mathrm{C}$. Insets: Signals consistent with the identification of the resting state of Ru as 1. 

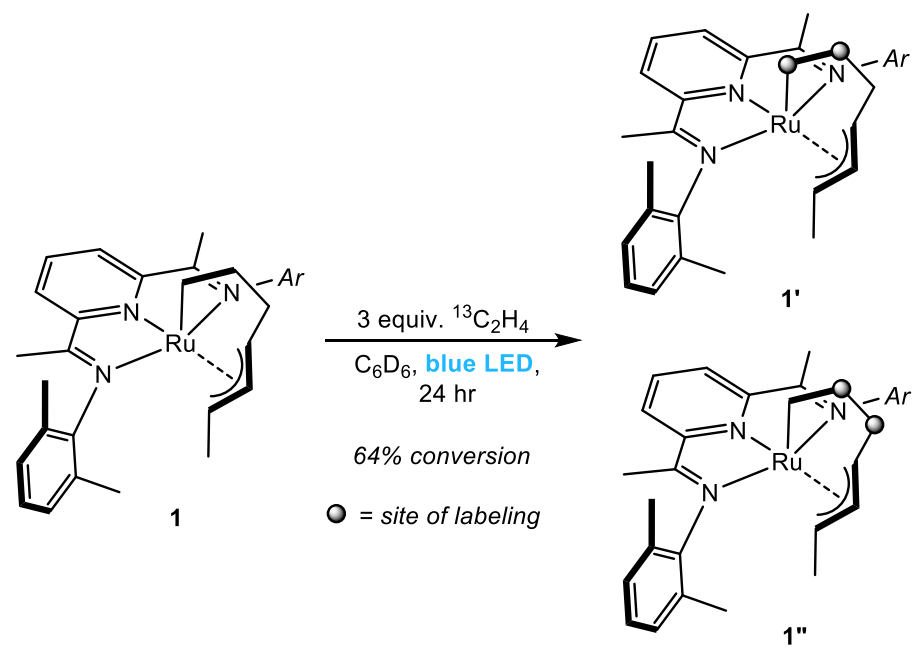

+ isomers

Stoichiometric Reactivity of 1 with ${ }^{13} \mathrm{C}$-Labeled Ethylene Under Irradiation. To a J. Young tube in the glove box was added a solution of $0.011 \mathrm{mg}(0.0194 \mathrm{mmol})$ of $1 \mathrm{in} 0.500 \mathrm{~mL} \mathrm{C}_{6} \mathrm{D}_{6}$. The tube was capped and the contents frozen in liquid nitrogen after which 0.0582 (3 equiv.) of ${ }^{13} \mathrm{C}$-labeled ethylene was added using a calibrated gas bulb. The solution was thawed in a room temperature water bath and irradiated with two $427 \mathrm{~nm}$ Kessil ${ }^{\mathrm{TM}}$ lamps for 24 hours without inversion. After 24 hours, the product mixture was analyzed by ${ }^{1} \mathrm{H}$ and ${ }^{13} \mathrm{C}\left\{{ }^{1} \mathrm{H}\right\}$ NMR spectroscopy. Analysis by NMR indicated the formation of isotopomers consistent with scrambling of the ${ }^{13} \mathrm{C}$ label into the metallacycle along with other products consistent with metallacycles arising from the asymmetry of piperylene. The ${ }^{1} \mathrm{H}$ and ${ }^{13} \mathrm{C}\left\{{ }^{1} \mathrm{H}\right\}$ NMR are presented in Figure S22A and S22B, respectively.

The scrambling pattern obtained from this experiment is inconsistent with only a retro-[2+2] process occurring, which would only place ${ }^{13} \mathrm{C}$ labels in the $\alpha$ and $\beta$ positions of $\mathbf{1}$ to generate $\mathbf{1}^{\prime}$. Instead, the labeling pattern is consistent with reductive coupling and rotation of the formed cyclobutane (Scheme S1). The side products evident by ${ }^{13} \mathrm{C}$ NMR are hypothesized to arise from an oxidative cyclization sequence with the piperylene methyl group in the internal position of the metallacycle. Side products can also arise from a retro-[2+2] process from 1' or 1", which would produce ethylene and piperylene moieties with only one ${ }^{13} \mathrm{C}$ label. Iterations of oxidative 
cyclization from these species would also scramble the label throughout the metallacycle fragment; the net total of all possible scrambling processes is shown in Scheme S1. Taken together, the scrambling pattern observed producing 1' and 1"' is indicative of $\mathrm{C}-\mathrm{C}$ bond forming reductive coupling at (PDI)Ru.

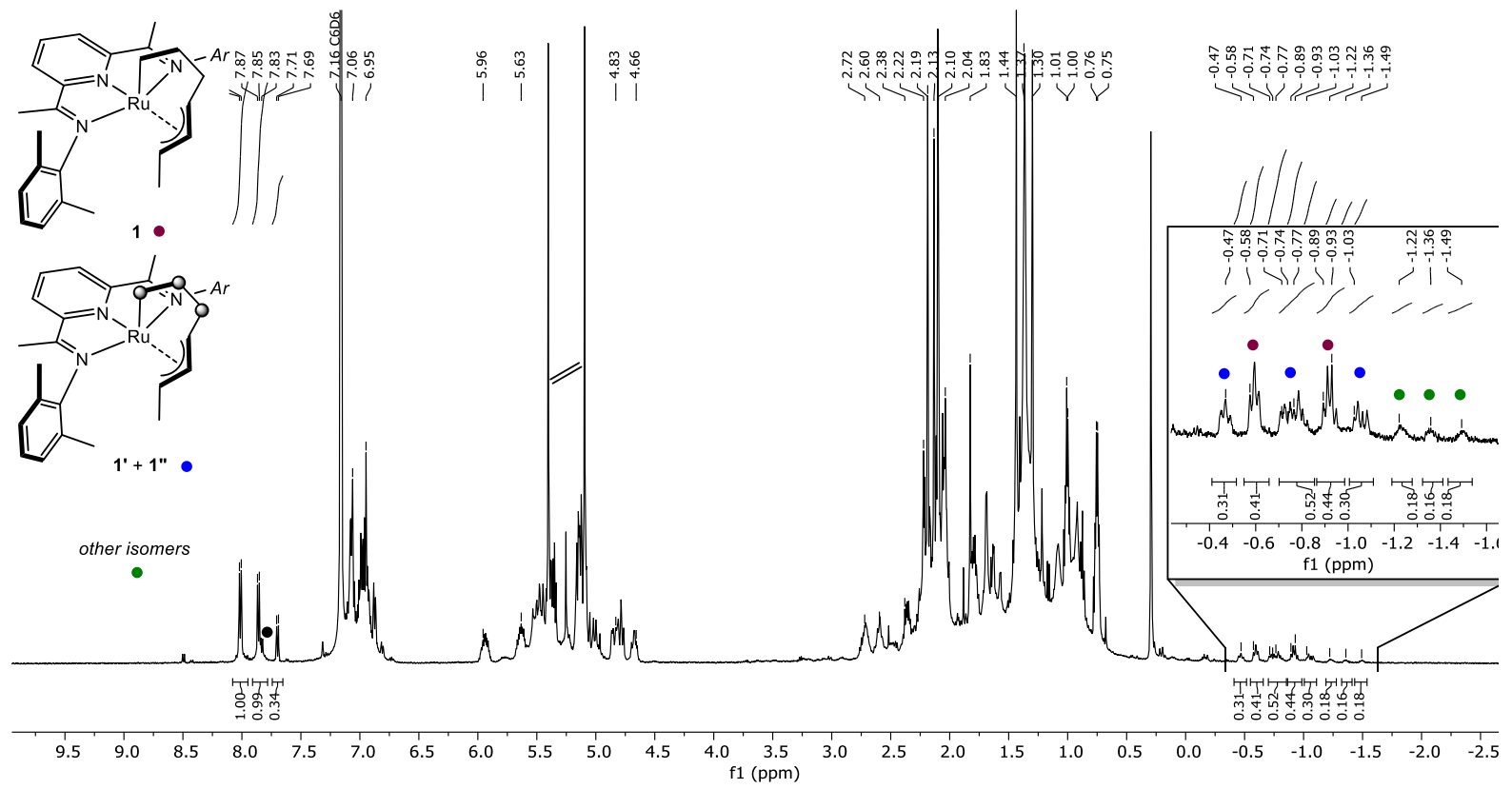

Figure S22A. ${ }^{1} \mathrm{H}$ NMR $\left(500 \mathrm{MHz}, \mathrm{C}_{6} \mathrm{D}_{6}, 25^{\circ} \mathrm{C}\right)$ spectrum of the products from the irradiation of 1 with a blue LED for 24 hours. Partial assignment of the isotopomers is given. Inset: assignment of Ru-alkyl bond region.

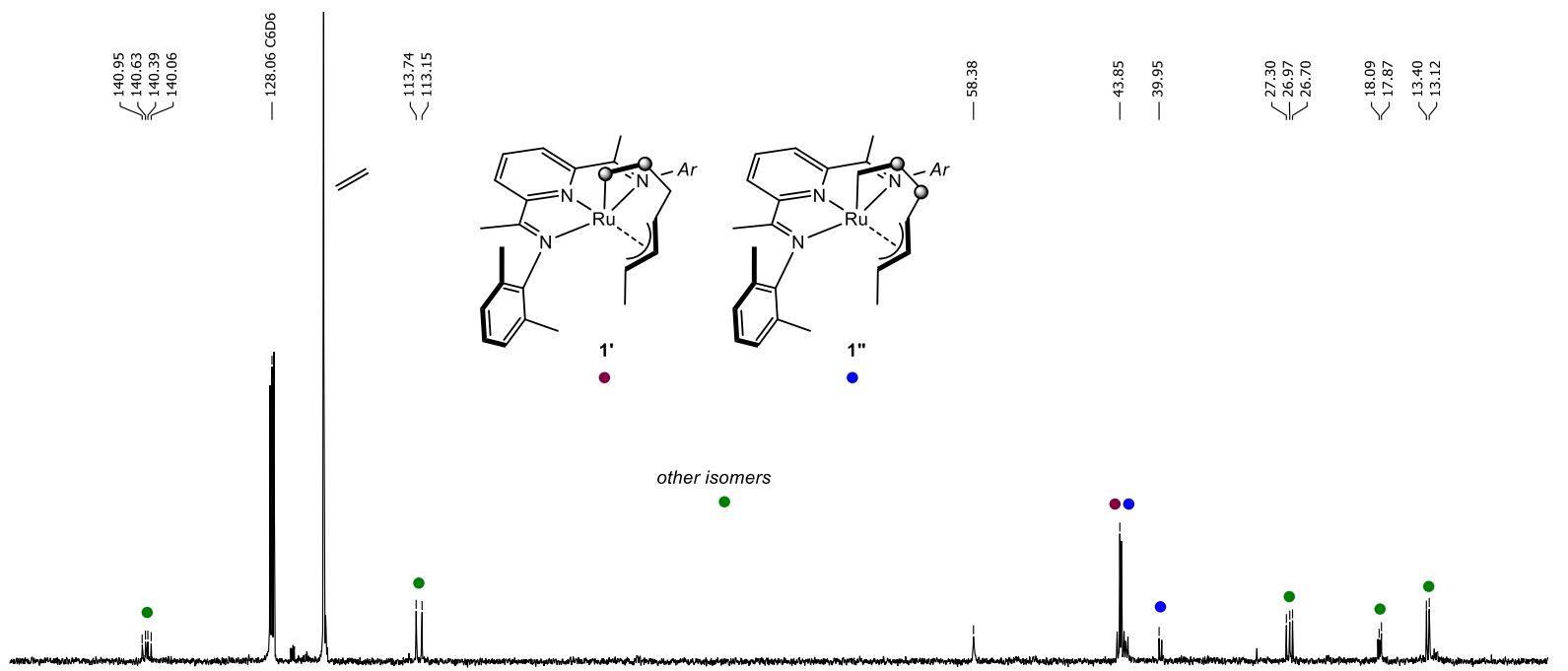

$\begin{array}{llllllllllllllllllllllllllllllll}150 & 145 & 140 & 135 & 130 & 125 & 120 & 115 & 110 & 105 & 100 & 95 & 90 & 85 & \begin{array}{c}80 \\ \mathrm{f} 1(\mathrm{ppm})\end{array} & 70 & 65 & 60 & 55 & 50 & 45 & 40 & 35 & 30 & 25 & 20 & 15 & 10 & 5\end{array}$

Figure S22B. ${ }^{13} \mathrm{C}\left\{{ }^{1} \mathrm{H}\right\} \mathrm{NMR}\left(500 \mathrm{MHz}, \mathrm{C}_{6} \mathrm{D}_{6}, 25^{\circ} \mathrm{C}\right)$ spectrum of the products from the irradiation of 1 with a blue LED for 24 hours. Partial assignment of the isotopomers is given. 
Retro-[2+2] Only:

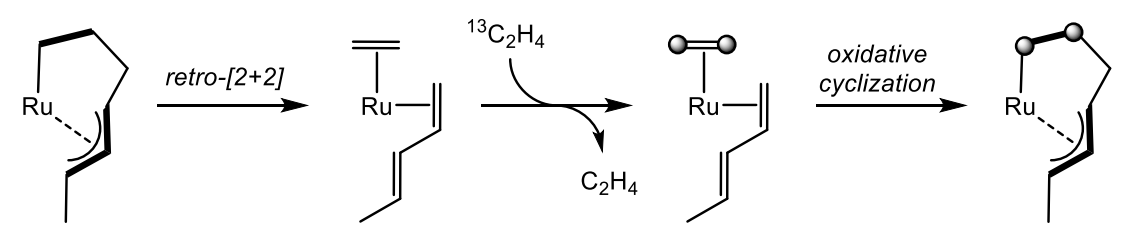

Reductive Coupling:
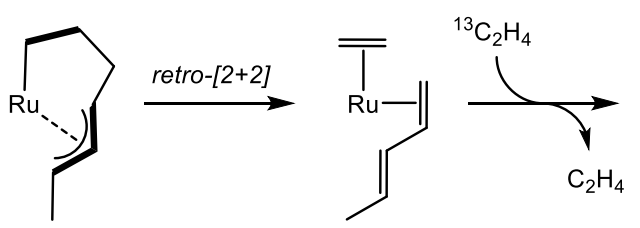<smiles>C=C/C=C\C=C/[R1]=O</smiles>

oxidative

cyclization
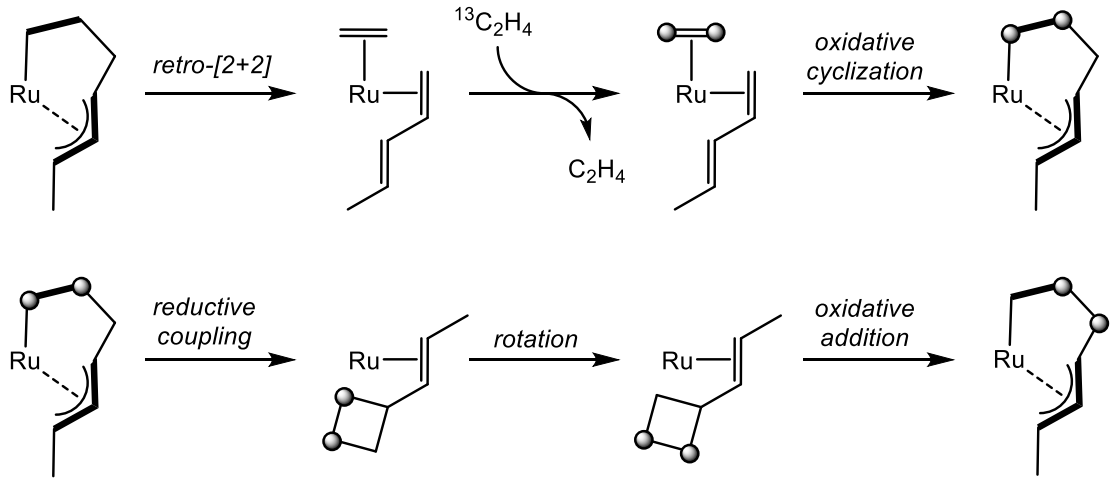

Possible Side Products From Asymmetric Piperylene:

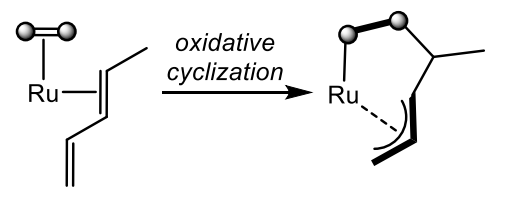

Possible Side Products From Retro-[2+2] of 1":
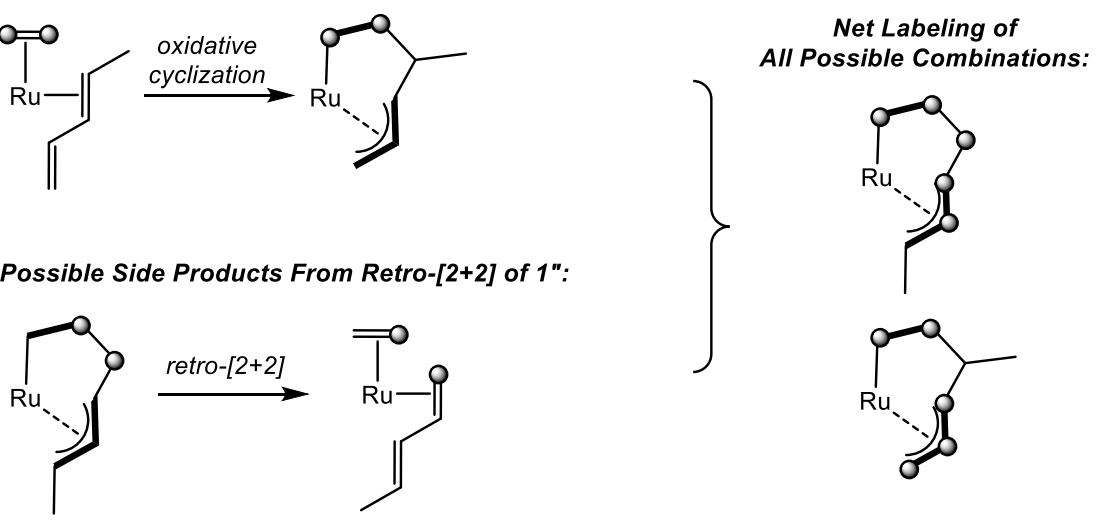

Scheme S1. Mechanisms of label scrambling in the metallacyclic fragment accounting for the observed isotopic patterns. 


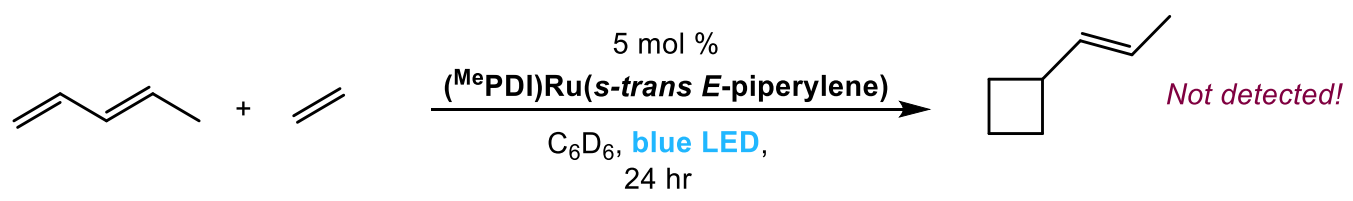

Catalytic Competence of (MePDI)Ru(s-trans E-piperylene) in [2+2] Cycloaddition Under

Irradiation. A J. Young tube was prepared as described in General Procedure B: [2+2]

Cycloaddition of Piperylene and Ethylene. The tube was then irradiated with two $427 \mathrm{~nm}$

Kessil $^{\mathrm{TM}}$ lamps for 24 hours without inversion. After 24 hours, the product mixture was analyzed by ${ }^{1} \mathrm{H}$ NMR spectroscopy and no propenylcyclobutane was detected (Figure S23).

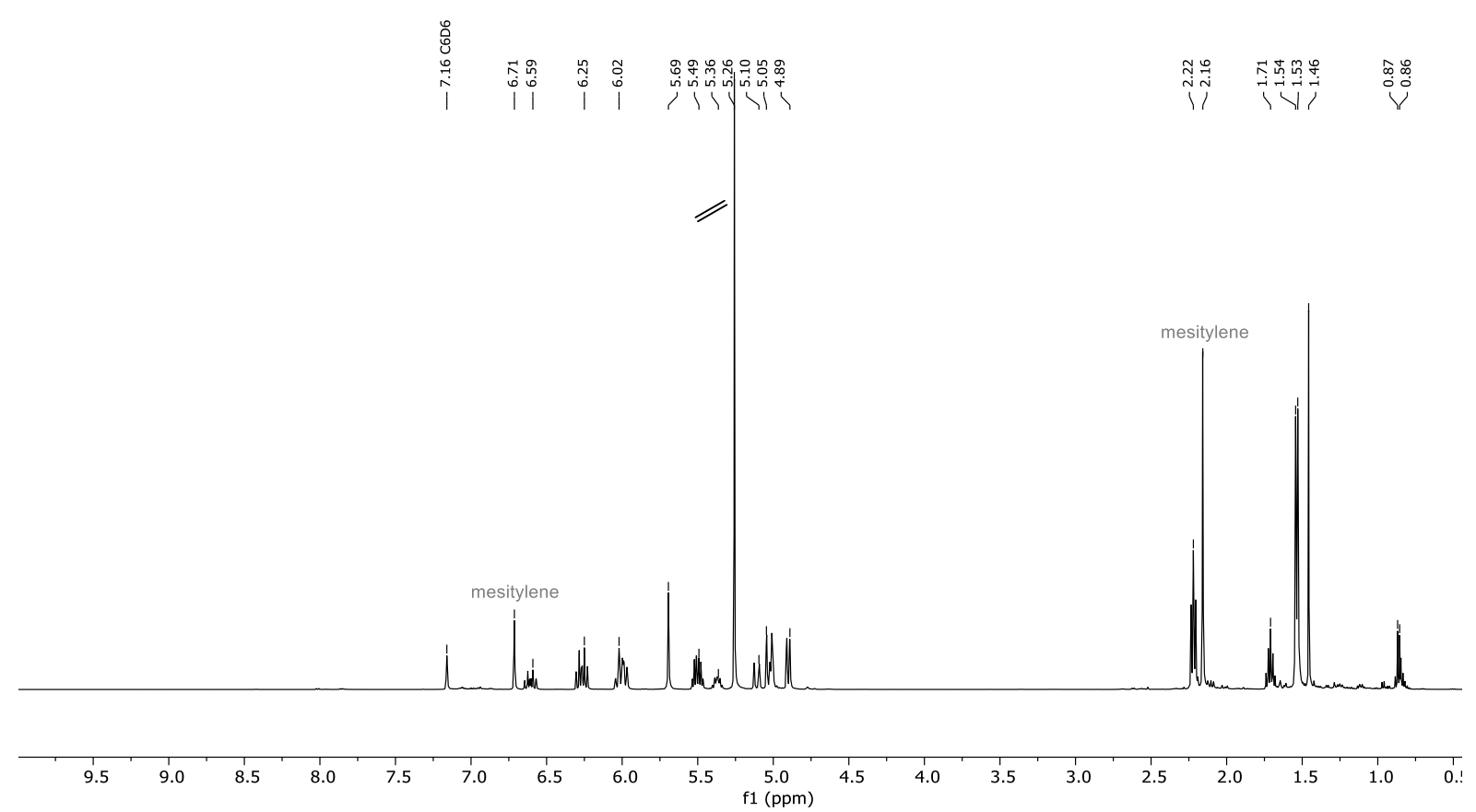

Figure S23. ${ }^{1} \mathrm{H}$ NMR $\left(400 \mathrm{MHz}, \mathrm{C}_{6} \mathrm{D}_{6}, 25^{\circ} \mathrm{C}\right)$ spectrum of the [2+2] cycloaddition of piperylene and ethylene catalyzed by (MePDI)Ru(s-trans E-piperylene) after 24 hours of irradiation. 


\section{Experiments Relevant to Retro-[2+2] Cyclization}

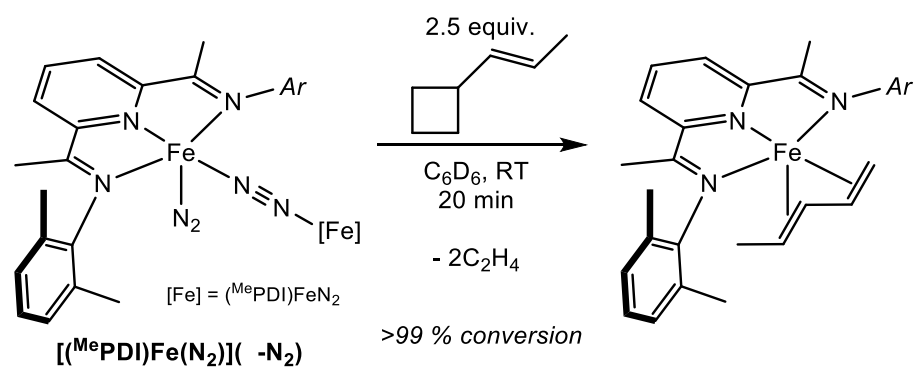

Identification of Speciation of [Fe] in the Retro-Cyclization of Propenylcyclobutane. To a J. Young tube in the glove box was added a solution of $0.009 \mathrm{mg}(0.00963 \mathrm{mmol})$ of [( $\left.\left.{ }^{\mathrm{Me} P D I}\right) \mathrm{Fe}\left(\mathbf{N}_{2}\right)\right]\left(\boldsymbol{\mu}-\mathbf{N}_{2}\right)$ in $0.400 \mathrm{~mL} \mathrm{C} \mathrm{D}_{6}$. A stock solution of $0.006 \mathrm{mg}(0.0722 \mathrm{mmol})$ of $E$ propenylcyclobutane in $0.300 \mathrm{~mL} \mathrm{C}_{6} \mathrm{D}_{6}$ was prepared of which $0.100 \mathrm{~mL}(0.0241 \mathrm{mmol}, 2.5$ equiv. E-propenylcyclobutane) was added to the J. Young tube. The tube was capped and the contents mixed by inversion for 20 minutes after which the product mixture was analyzed by ${ }^{1} \mathrm{H}$ NMR spectroscopy. The ${ }^{1} \mathrm{H}$ NMR spectrum is presented in Figure S24A and indicates that the observable Fe species in solution is ( $\left.{ }^{\mathrm{e}} \mathrm{PDI}\right) \mathrm{Fe}(\boldsymbol{s}$-trans E-piperylene) by comparison to literature data. $^{3}$

In order to rule out the presence of NMR-silent iron-containing species in this reaction, the reaction was analyzed by solution Mössbauer at $80 \mathrm{~K}$. To a vial containing a stir bar in the glove box was added $0.065 \mathrm{~g}(0.0695 \mathrm{mmol})$ of $\left[\left({ }^{\mathrm{Me}} \mathrm{PDI}\right) \mathrm{Fe}\left(\mathbf{N}_{\mathbf{2}}\right)\right]\left(\boldsymbol{\mu}-\mathbf{N}_{\mathbf{2}}\right)$ in $1 \mathrm{~mL}$ of $\mathrm{C}_{6} \mathrm{H}_{6} .0 .017 \mathrm{~g}$ of $E-$ propenylcyclobutane $(0.173 \mathrm{mmol}, 2.5$ equiv. $)$ was weighed directly into the vial. The vial was capped and stirred at room temperature for 10 minutes, after which the solution was transferred into the solution Mössbauer sample holder and frozen. A Mössbauer spectrum was obtained at $80 \mathrm{~K}$ and confirmed that the sole iron-containing species in the reaction is ( $\left.{ }^{\mathrm{Me}} \mathrm{PDI}\right) \mathrm{Fe}(\mathrm{s}$-trans Epiperylene) based on comparison of the obtained parameters to literature data. ${ }^{3}$ The Mössbauer spectrum is presented in Figure S24B. 


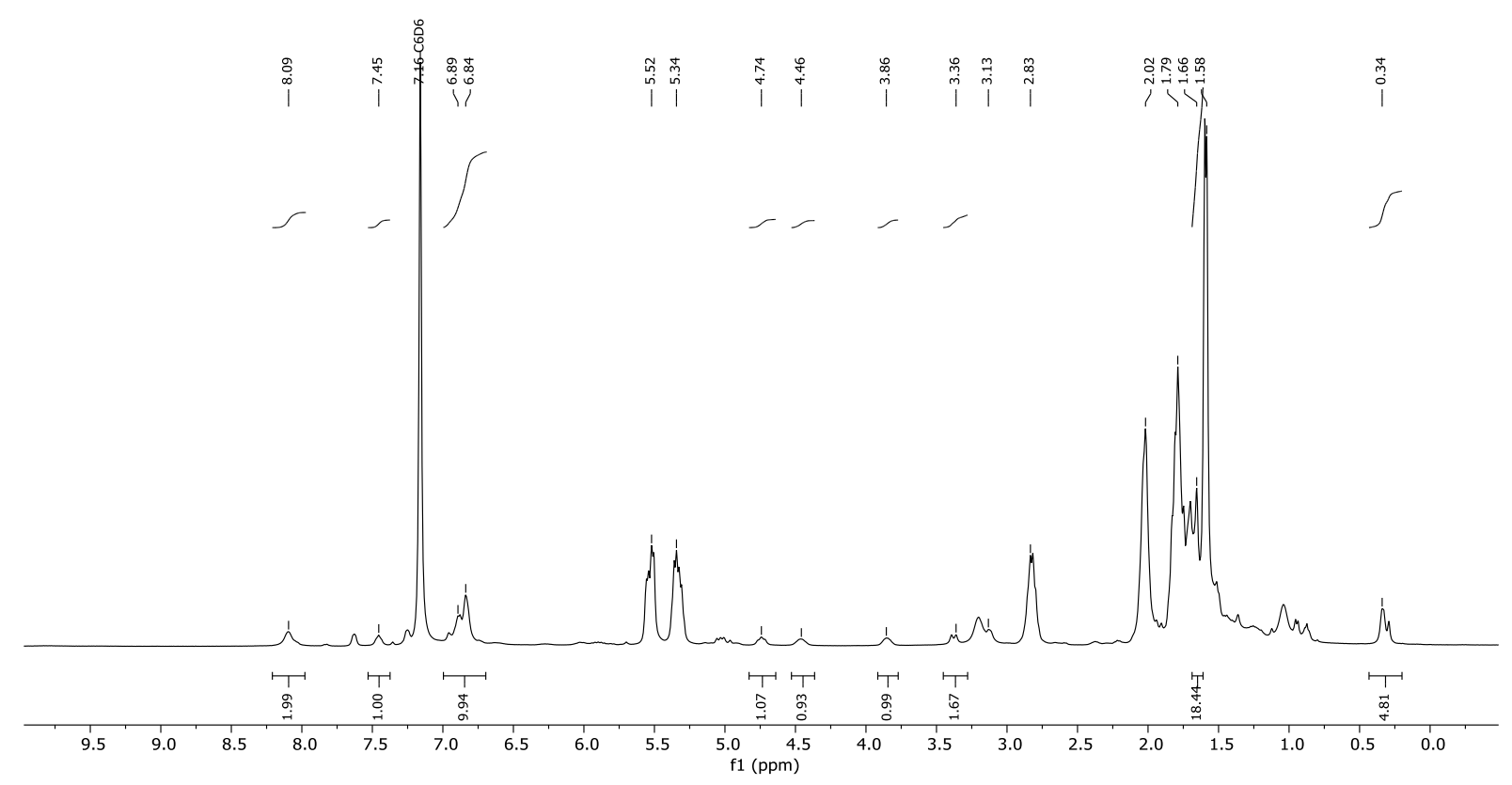

Figure S24A. ${ }^{1} \mathrm{H}$ NMR $\left(400 \mathrm{MHz}, \mathrm{C}_{6} \mathrm{D}_{6}, 2^{\circ} \mathrm{C}\right)$ spectrum of the products resulting from retro-[2+2] cyclization of propenylcyclobutane with [( $\left.\left.{ }^{\mathrm{MePDI}}\right) \mathrm{Fe}\left(\mathrm{N}_{2}\right)\right]\left(\boldsymbol{\mu}-\mathrm{N}_{2}\right)$.

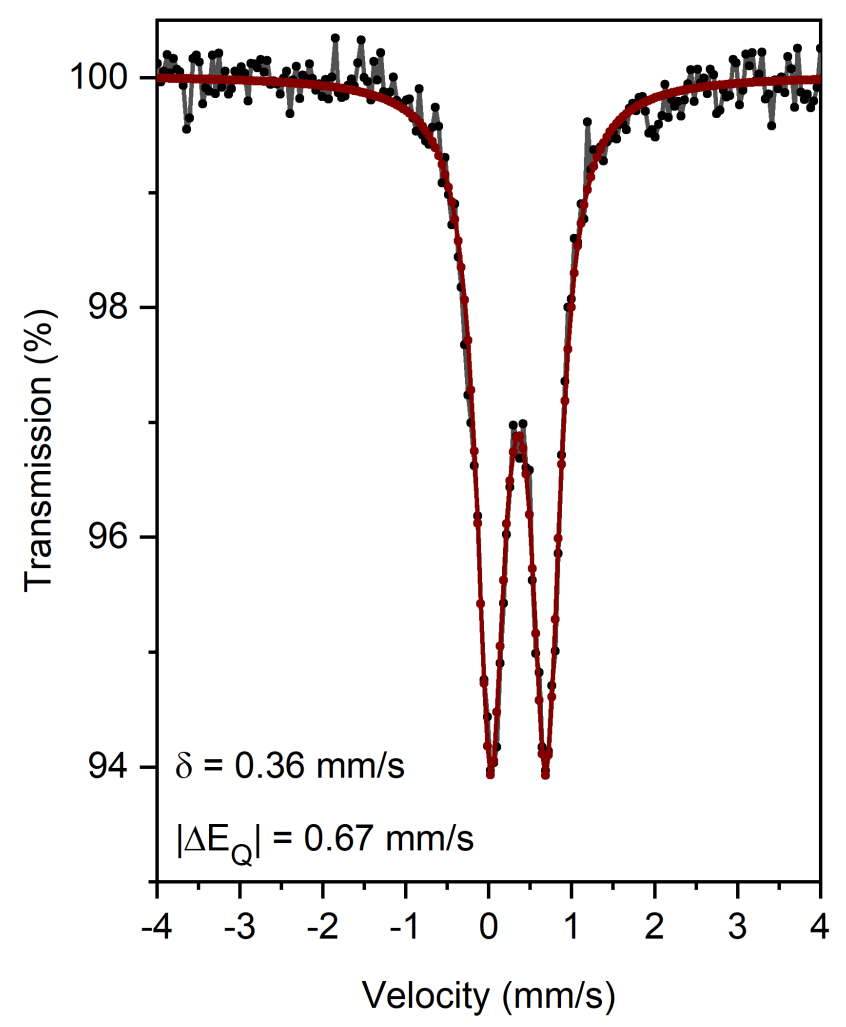

Figure S24B. Frozen-solution state $(80 \mathrm{~K})$ Mössbauer spectrum of products resulting from retro-[2+2] cyclization of propenylcyclobutane with [( $\left.\left.{ }^{\mathrm{Me}} \mathrm{PDI}\right) \mathrm{Fe}\left(\mathbf{N}_{\mathbf{2}}\right)\right]\left(\boldsymbol{\mu}-\mathbf{N}_{\mathbf{2}}\right)$. The experimental data (grey trace) was fit to the following parameters: $\delta=0.36 \mathrm{~mm} \mathrm{~s}^{-1},\left|\Delta \mathrm{E}_{\mathrm{Q}}\right|=0.67 \mathrm{~mm} \mathrm{~s}^{-1}$. The fit is shown in red. 

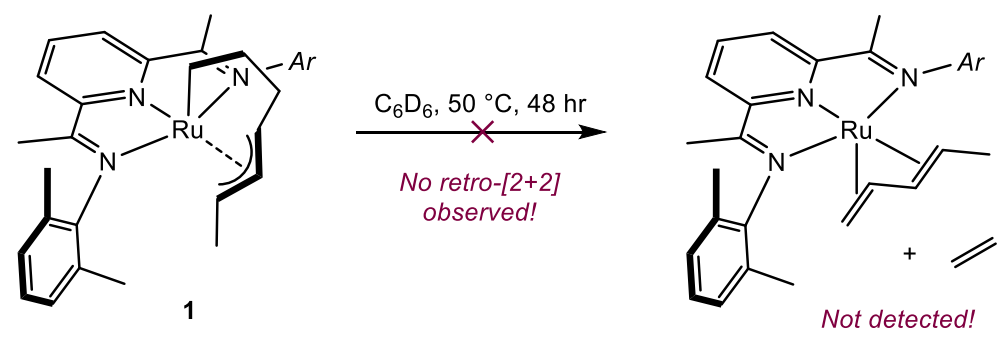

Attempted Thermal Retrocyclization of 1. To a J. Young tube in the glove box was added a solution of $0.008 \mathrm{~g}(0.0141 \mathrm{mmol})$ of $1 \mathrm{in} 0.500 \mathrm{~mL}$ of $\mathrm{C}_{6} \mathrm{D}_{6}$. The tube was capped and placed in an oil bath at $50^{\circ} \mathrm{C}$ for 24 hours without inversion, after which a ${ }^{1} \mathrm{H}$ NMR spectrum was recorded. Analysis of the reaction mixture by ${ }^{1} \mathrm{H}$ NMR spectroscopy indicated that no reaction had occurred; the identity of the ruthenium in the reaction mixture was determined to be 1 . The ${ }^{1} \mathrm{H}$ NMR spectrum is given in Figure S25.

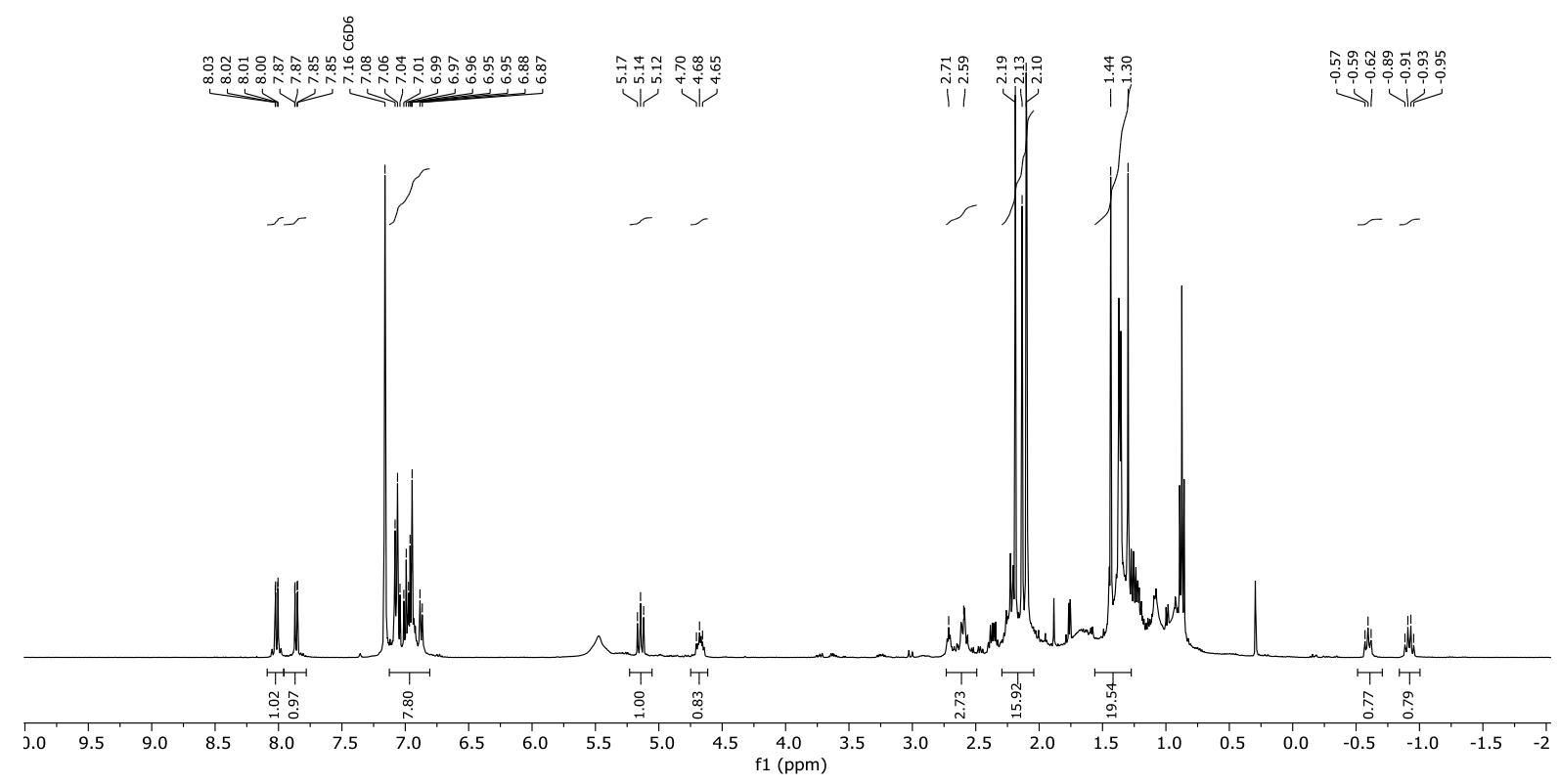

Figure S25. ${ }^{1} \mathrm{H} \mathrm{NMR}\left(400 \mathrm{MHz}, \mathrm{C}_{6} \mathrm{D}_{6}, 25^{\circ} \mathrm{C}\right)$ spectrum of the reaction mixture obtained from heating 1 for 24 hours at $50^{\circ} \mathrm{C}$. 

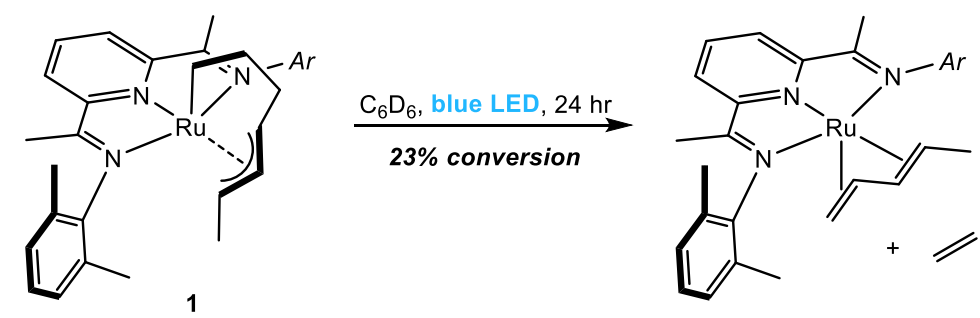

Photoinduced Retro-Cyclization of 1. To a J. Young tube in the glove box was added a solution of $0.008 \mathrm{~g}(0.0141 \mathrm{mmol})$ of $1 \mathrm{in} 0.500 \mathrm{~mL}$ of $\mathrm{C}_{6} \mathrm{D}_{6}$. The tube was capped and irradiated with two $427 \mathrm{~nm}$ Kessil ${ }^{\mathrm{TM}}$ lamps for 24 hours without inversion, after which a ${ }^{1} \mathrm{H}$ NMR spectrum was obtained. Analysis of the reaction mixture by ${ }^{1} \mathrm{H}$ NMR indicated the presence of (MePDI)Ru(strans E-piperylene) and free ethylene in $23 \%$ conversion. The ${ }^{1} \mathrm{H}$ NMR spectrum is given in Figure S26.

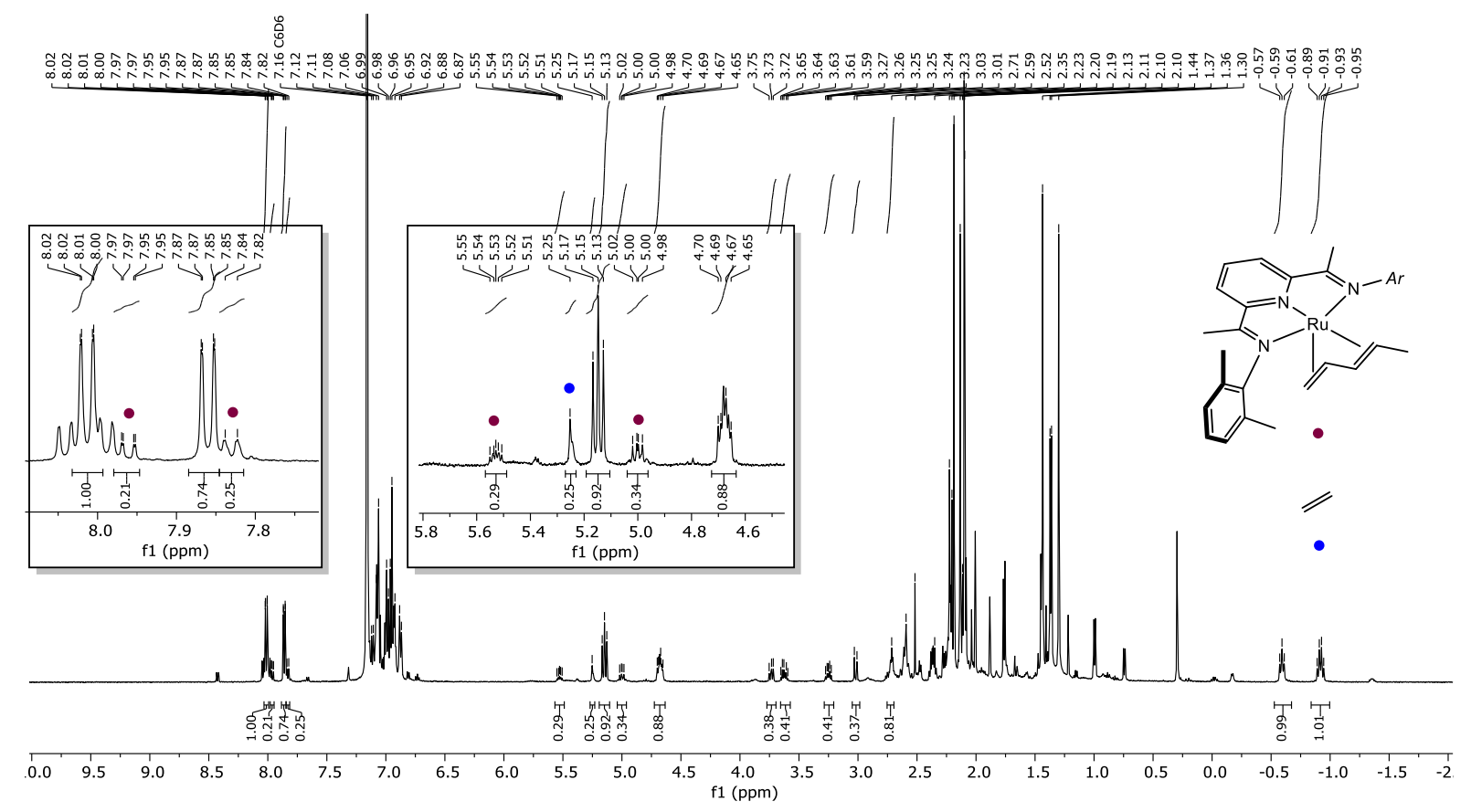

Figure S26. ${ }^{1} \mathrm{H}$ NMR $\left(500 \mathrm{MHz}, \mathrm{C}_{6} \mathrm{D}_{6}, 25^{\circ} \mathrm{C}\right)$ spectrum of the reaction mixture obtained from irradiating 1 with a blue LED for 24 hours. Annotations of peaks corresponding to (MePDI)Ru(s-trans E-piperylene) and free ethylene are given. 


\section{Computational Details}

Geometry Optimizations as a Function of Plane Angle. Density functional calculations (DFT) were performed with Amsterdam Density Functional (ADF) version 2019 release $73461 .^{13}$ Geometries were optimized with the appropriate dihedral constrained. ADF calculations employed the zeroth-order scalar relativistic approximation (ZORA), BP86 or B3LYP functionals with integration over a "good quality" grid, Grimme D3 dispersion corrections, and a TZ2P basis set. $^{14-22}$ Within ADF, ZORA/TZ2P is a slater-type basis set of triple-zeta quality with two polarization functions. A frozen-core approximation was not employed.

Calculations on Reaction Spin Surface. DFT calculations were performed with Jaguar version 10.8, release $72 .{ }^{23-24}$ Geometries were optimized at restricted Kohn-Sham (RKS), unrestricted (UKS) and broken-symmetry (BS) stationary points. In broken-symmetry notation, BS $(m, n)$ describes a state where there are $m$ unpaired spin up electrons and $n$ unpaired spin down electrons on separate fragments. For example, to obtain a $\mathrm{BS}(3,1)$ triplet state where there are three unpaired up spins on the ferric iron (site A) antiferromagnetically coupled to one unpaired down spin on the reduced ligand (site B), first the complex was optimized as an unrestricted highspin quintet, in other words UKS(S=5). Second, the highest virtual ligand orbital and highest occupied iron orbital are swapped in the input basis guess and the resulting spin densities of the converged triplet self-consistent field calculation checked to ensure a ferric iron and a reduced ligand. An analogous procedure was followed to generate the BS $(1,1)$ singlet state starting from the optimized UKS(S=1) triplet. The results from these calculations are labeled as $\mathrm{BS}(3,1) / / \mathrm{UKS}(\mathrm{S}=5)$ and $\mathrm{BS}(1,1) / / \mathrm{UKS}(\mathrm{S}=1)$ signifying a single-point at the optimized high-spin unrestricted geometry. Further, these BS single points were used as starting points for additional geometry optimizations along the BS spin manifold (e.g. BS(3,1)//BS(3,1)). Both UKS and BS suffer from spin contamination. For the latter, the spin contamination is substantial because the BS electronic state is not an eigenfunction of the single determinant spin Hamiltonian, therefore 
the absolute value of the energy is suspect. The Yamaguchi spin-projection approach is used to obtain the spin-projected energies given the following spin Hamiltonian: ${ }^{25-26}$

$$
H=-2 J S_{A} S_{B}
$$

The value of the exchange coupling constant $J$ can be approximated from the energies and spin expectation values of the of the high-spin and broken-symmetry states (at the given geometry):

$$
J=-\frac{E_{H S}-E_{B S}}{\left\langle\widehat{S}^{2}\right\rangle_{H S}-\left\langle\widehat{\boldsymbol{S}}^{2}\right\rangle_{B S}}
$$

If $J<0$, than the BS state is higher in energy than the true antiferromagnetic multi-determinant state. The following spin ladder is then used to approximate the energy of the multi-determinant state:

$$
E(S-1)=E(S)+2 J S ; S=S_{A}+S_{B}
$$

Jaguar calculations employed the TPSS functional with integration over a "fine" grid. ${ }^{27-29}$ LACVP features an effective core potential for iron and a 6-31G Pople basis set for all other atoms. ${ }^{30}$ LACV3P is the triple-zeta contraction of the LACVP basis set. Additional diffuse (+) and polarization $\left({ }^{*}\right)$ functions follow standard conventions. Vibrational mode analysis confirmed minima and saddle points.

Table S5. TPSS/LAC3VP ${ }^{* *}+/ / L A C V P^{* *}$ energies. Optimization of BS $(1,1) / / B S(1,1)$ collapsed to the restricted KohnSham (RKS) solution. The reported $\Delta \mathrm{G}_{298 \mathrm{~K}}$ values are spin-ladder corrected.

\begin{tabular}{|c|c|c|c|c|c|c|}
\hline & \multicolumn{3}{|c|}{ Singlet (S=0) } & \multicolumn{3}{c|}{ Triplet $(\mathrm{S}=1)$} \\
\hline & $\mathrm{RKS}(\mathrm{S}=0)$ & $\begin{array}{c}\mathrm{BS}(1,1) / / \\
\mathrm{BS}(1,1)\end{array}$ & $\begin{array}{c}\mathrm{BS}(1,1) / / \\
\mathrm{UKS}(\mathrm{S}=1)\end{array}$ & UKS(S=1) & $\begin{array}{c}\mathrm{BS}(3,1) / / \\
\mathrm{BS}(3,1)\end{array}$ & $\begin{array}{c}\mathrm{BS}(3,1) / / \\
\text { UKS(S=2) }\end{array}$ \\
\hline$J\left(\mathrm{~cm}^{-1}\right)$ & $\mathrm{N} / \mathrm{A}$ & $\mathrm{RKS}$ & 3536 & $\mathrm{~N} / \mathrm{A}$ & -1994 & -1142 \\
\hline$\Delta \mathrm{G}_{298 \mathrm{~K}}(\mathrm{kcal} / \mathrm{mol})$ & 0 & 0 & 43.4 & 3.1 & 1.4 & 1.9 \\
\hline Boltzmann population & & & & $0.6 \%$ & $8.5 \%$ & $4.1 \%$ \\
\hline
\end{tabular}




\section{Crystallographic Data}

\section{Crystallographic Data for (PNP)Fe(s-cis $\left.\mathrm{C}_{4} \mathrm{H}_{6}\right)$.}

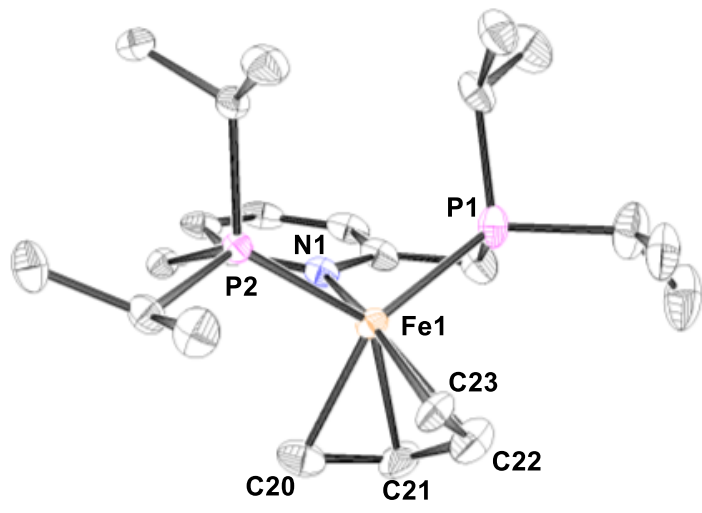

\begin{tabular}{|c|c|}
\hline \multicolumn{2}{|c|}{ Crystal data } \\
\hline Chemical formula & $\mathrm{C}_{23} \mathrm{H}_{41} \mathrm{FeNP}_{2}$ \\
\hline$M_{\mathrm{r}}$ & 449.36 \\
\hline Crystal system, space group & Orthorhombic, Pbca \\
\hline Temperature $(\mathrm{K})$ & 100 \\
\hline$a, b, c(\AA)$ & $10.1045(2), 15.3342(3), 30.4516(6)$ \\
\hline$V\left(\AA^{3}\right)$ & $4718.31(16)$ \\
\hline Z & 8 \\
\hline Radiation type & $\mathrm{Cu} \mathrm{Ka}$ \\
\hline $\mathrm{m}\left(\mathrm{mm}^{-1}\right)$ & 6.45 \\
\hline Crystal size (mm) & $0.11 \times 0.09 \times 0.05$ \\
\hline \multicolumn{2}{|c|}{ Data collection } \\
\hline Diffractometer & Bruker D8 Venture Photon 100 CMOS \\
\hline Absorption correction & $\begin{array}{c}\text { Multi-scan } \\
\text { TWINABS BRUKER AXS }\end{array}$ \\
\hline$T_{\min }, T_{\max }$ & $0.645,0.753$ \\
\hline $\begin{array}{l}\text { No. of measured, independent and } \\
\text { observed }[I>2 \mathrm{~s}(I)] \text { reflections }\end{array}$ & $87108,4167,3561$ \\
\hline$R_{\text {int }}$ & 0.069 \\
\hline$(\sin q / l)_{\max }\left(\AA^{-1}\right)$ & 0.595 \\
\hline \multicolumn{2}{|c|}{ Refinement } \\
\hline$R\left[F^{2}>2 \mathrm{~s}\left(F^{2}\right)\right], w R\left(F^{2}\right), S$ & $0.041,0.108,1.03$ \\
\hline No. of reflections & 4167 \\
\hline No. of parameters & 244 \\
\hline $\mathrm{H}$-atom treatment & $\mathrm{H}$-atom parameters constrained \\
\hline$D \tilde{n}_{\max }, D \tilde{n}_{\min }\left(e \AA^{-3}\right)$ & $1.34,-0.67$ \\
\hline
\end{tabular}

Computer programs: Bruker APEX3, Bruker SAINT, SHELXT 2014/5 (Sheldrick, 2014), SHELXL2018/3 (Sheldrick, 2018), ORTEP-3 (Farraguia, 1994). 


\section{Crystallographic Data for (PNN)Fe(s-cis $\left.\mathrm{C}_{4} \mathrm{H}_{6}\right)$.}

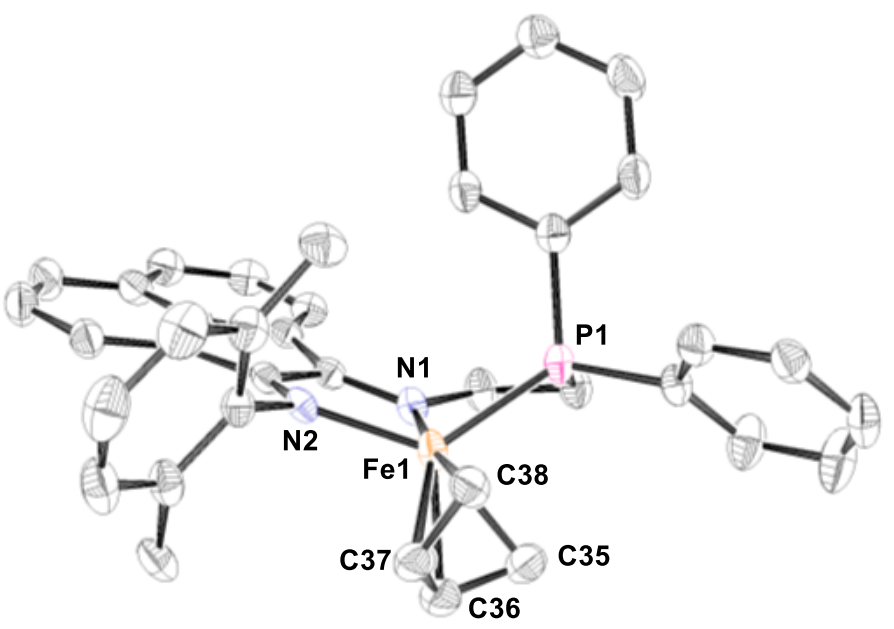

\begin{tabular}{|c|c|}
\hline \multicolumn{2}{|c|}{ Crystal data } \\
\hline Chemical formula & $\mathrm{C}_{38} \mathrm{H}_{35} \mathrm{FeN}_{2} \mathrm{P}$ \\
\hline$M_{\mathrm{r}}$ & 606.50 \\
\hline Crystal system, space group & Monoclinic, $P 2_{1} / c$ \\
\hline Temperature $(\mathrm{K})$ & 100 \\
\hline$a, b, c(\AA)$ & $11.8004(4), 18.0957(6), 15.3242(5)$ \\
\hline $\mathrm{b}\left({ }^{\circ}\right)$ & $101.826(2)$ \\
\hline$V\left(\AA^{3}\right)$ & $3202.82(19)$ \\
\hline$Z$ & 4 \\
\hline Radiation type & $\mathrm{Cu} \mathrm{Ka}$ \\
\hline $\mathrm{m}\left(\mathrm{mm}^{-1}\right)$ & 4.45 \\
\hline Crystal size (mm) & $0.10 \times 0.07 \times 0.04$ \\
\hline \multicolumn{2}{|c|}{ Data collection } \\
\hline Diffractometer & Bruker APEX-II CCD \\
\hline Absorption correction & $\begin{array}{c}\text { Multi-scan } \\
\text { twinabs bruker axs }\end{array}$ \\
\hline$T_{\min }, T_{\max }$ & $0.668,0.754$ \\
\hline $\begin{array}{l}\text { No. of measured, independent and } \\
\text { observed }[I>2 \mathrm{~s}(I)] \text { reflections }\end{array}$ & $20256,6230,5047$ \\
\hline$R_{\text {int }}$ & 0.052 \\
\hline$(\sin q / l)_{\max }\left(\AA^{-1}\right)$ & 0.618 \\
\hline \multicolumn{2}{|c|}{ Refinement } \\
\hline$R\left[F^{2}>2 \mathrm{~s}\left(F^{2}\right)\right], w R\left(F^{2}\right), S$ & $0.050,0.130,1.04$ \\
\hline No. of reflections & 6230 \\
\hline No. of parameters & 381 \\
\hline $\mathrm{H}$-atom treatment & $\mathrm{H}$-atom parameters constrained \\
\hline $\mathrm{D} \tilde{n}_{\max }, \mathrm{D} \tilde{n}_{\min }\left(\mathrm{e} \AA^{-3}\right)$ & $1.12,-0.99$ \\
\hline
\end{tabular}

Computer programs: Bruker APEX2, Bruker SAINT, SHELXS97 (Sheldrick 2008), SHELXL2014 (Sheldrick 2014), Bruker SHELXTL. 


\section{Crystallographic Data for ( $\left.{ }^{\mathrm{Me}(\mathrm{Ph})} \mathrm{PDI}\right) \mathrm{Fe}\left(\mathrm{s}\right.$-trans $\left.\mathrm{C}_{4} \mathrm{H}_{6}\right)$.}

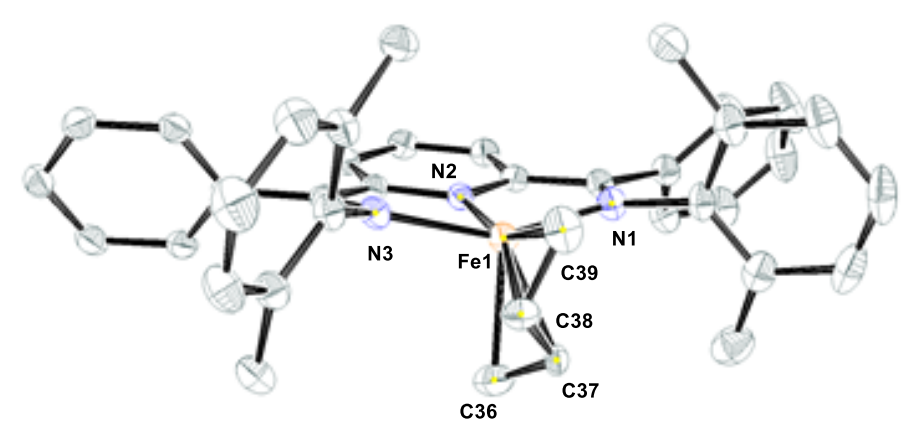

\begin{tabular}{|c|c|}
\hline \multicolumn{2}{|c|}{ Crystal data } \\
\hline Chemical formula & $\mathrm{C}_{39} \mathrm{H}_{37} \mathrm{FeN}_{3}$ \\
\hline$M_{\mathrm{r}}$ & 603.56 \\
\hline Crystal system, space group & Monoclinic, $I 2 / a$ \\
\hline Temperature $(\mathrm{K})$ & 100 \\
\hline$a, b, c(\AA)$ & $21.8718(19), 9.4176(8), 32.442(4)$ \\
\hline$\beta\left(^{\circ}\right)$ & $90.092(2)$ \\
\hline$V\left(\AA^{3}\right)$ & $6682.3(12)$ \\
\hline$Z$ & 8 \\
\hline Radiation type & Mo $K \alpha$ \\
\hline$\mu\left(\mathrm{mm}^{-1}\right)$ & 0.48 \\
\hline Crystal size $(\mathrm{mm})$ & $0.19 \times 0.19 \times 0.16$ \\
\hline \multicolumn{2}{|c|}{ Data collection } \\
\hline Diffractometer & Bruker $A P E X$-II CCD \\
\hline Absorption correction & $\begin{array}{c}\text { Multi-scan } \\
\text { TWINABS BRUKER AXS }\end{array}$ \\
\hline$T_{\min }, T_{\max }$ & $0.717,0.746$ \\
\hline $\begin{array}{l}\text { No. of measured, independent and } \\
\text { observed }[I>2 \sigma(I)] \text { reflections }\end{array}$ & $118240,8687,6257$ \\
\hline$R_{\text {int }}$ & 0.068 \\
\hline$(\sin \theta / \lambda)_{\max }\left(\AA^{-1}\right)$ & 0.678 \\
\hline \multicolumn{2}{|c|}{ Refinement } \\
\hline$R\left[F^{2}>2 \sigma\left(F^{2}\right)\right], w R\left(F^{2}\right), S$ & $0.050,0.163,1.04$ \\
\hline No. of reflections & 8687 \\
\hline No. of parameters & 407 \\
\hline H-atom treatment & H-atom parameters constrained \\
\hline$\left.\Delta\rangle_{\max }, \Delta\right\rangle_{\min }\left(\mathrm{e} \AA^{-3}\right)$ & $0.65,-0.62$ \\
\hline
\end{tabular}

Computer programs: Bruker APEX2, Bruker SAINT, SHELXT 2014/4 (Sheldrick, 2014), SHELXL2018/3 (Sheldrick, 2018). 


\section{Crystallographic Data for ("MePDI)Ru(s-trans E-piperylene).}

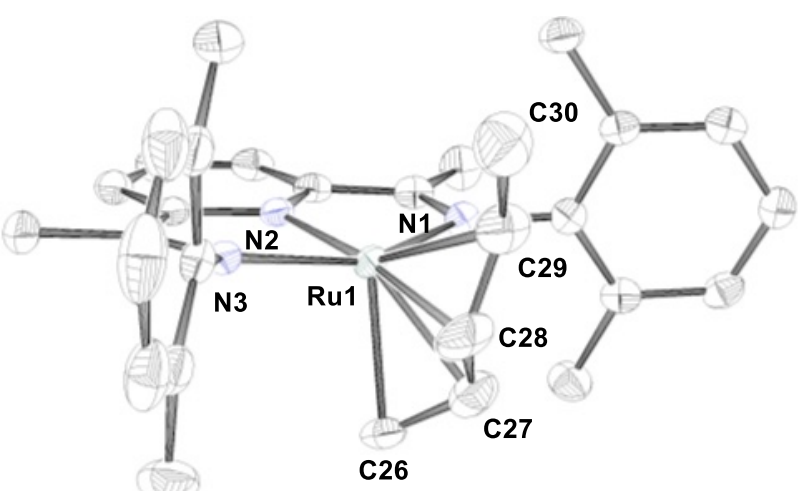

\begin{tabular}{|c|c|}
\hline \multicolumn{2}{|c|}{ Crystal data } \\
\hline Chemical formula & $\mathrm{C}_{30} \mathrm{H}_{35} \mathrm{~N}_{3} \mathrm{Ru}$ \\
\hline$M_{\mathrm{r}}$ & 538.68 \\
\hline Crystal system, space group & Triclinic, $P^{-} 1$ \\
\hline Temperature $(\mathrm{K})$ & 100 \\
\hline$a, b, c(\AA)$ & $10.6465(3), 11.8814(3), 12.3450(3)$ \\
\hline $\mathrm{a}, \mathrm{b}, \mathrm{g}\left(^{\circ}\right)$ & $63.137(1), 65.347(1), 85.598(1)$ \\
\hline$V\left(\AA^{3}\right)$ & $1254.02(6)$ \\
\hline $\bar{Z}$ & 2 \\
\hline Radiation type & $\mathrm{Cu} \mathrm{Ka}$ \\
\hline $\mathrm{m}\left(\mathrm{mm}^{-1}\right)$ & 5.22 \\
\hline Crystal size $(\mathrm{mm})$ & $0.07 \times 0.06 \times 0.03$ \\
\hline \multicolumn{2}{|c|}{ Data collection } \\
\hline Diffractometer & Bruker $A P E X$-II CCD \\
\hline Absorption correction & $\begin{array}{c}\text { Multi-scan } \\
\text { TWINABS BRUKER AXS }\end{array}$ \\
\hline$T_{\min }, T_{\max }$ & $0.674,0.753$ \\
\hline $\begin{array}{l}\text { No. of measured, independent and } \\
\text { observed }[I>2 \mathrm{~s}(I)] \text { reflections }\end{array}$ & $19080,4520,4351$ \\
\hline$R_{\text {int }}$ & 0.026 \\
\hline$(\sin \mathrm{q} / 1)_{\max }\left(\AA^{-1}\right)$ & 0.603 \\
\hline \multicolumn{2}{|c|}{ Refinement } \\
\hline$R\left[F^{2}>2 \mathrm{~s}\left(F^{2}\right)\right], w R\left(F^{2}\right), S$ & $0.031,0.083,1.05$ \\
\hline No. of reflections & 4520 \\
\hline No. of parameters & 314 \\
\hline $\mathrm{H}$-atom treatment & H-atom parameters constrained \\
\hline$D \tilde{n}_{\max }, D \tilde{n}_{\min }\left(\mathrm{e} \AA^{-3}\right)$ & $1.85,-0.56$ \\
\hline
\end{tabular}

Computer programs: Bruker APEX2, Bruker SAINT, SHELXS97 (Sheldrick 2008), SHELXL2014 (Sheldrick 2014), Bruker SHELXTL. 


\section{Crystallographic Data for 1.}

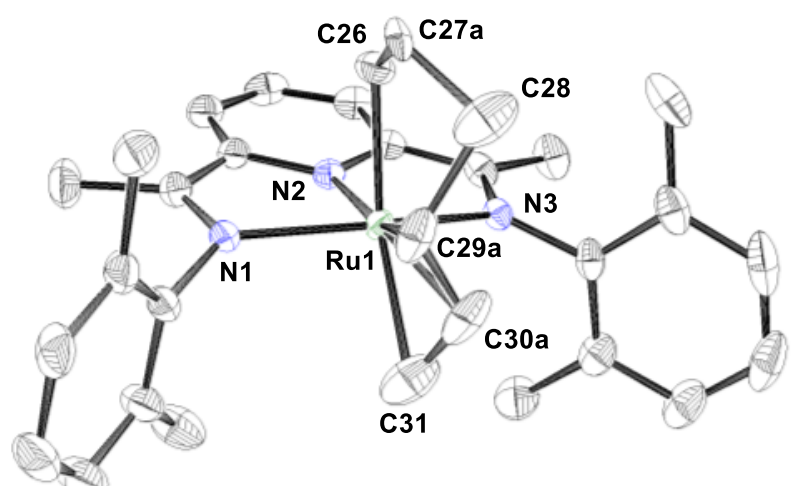

\begin{tabular}{|c|c|}
\hline \multicolumn{2}{|c|}{ Crystal data } \\
\hline Chemical formula & $\mathrm{C}_{31} \mathrm{H}_{37} \mathrm{~N}_{3} \mathrm{Ru}$ \\
\hline$M_{\mathrm{r}}$ & 552.70 \\
\hline Crystal system, space group & Orthorhombic, $\mathrm{Pbca}$ \\
\hline Temperature $(\mathrm{K})$ & 100 \\
\hline$a, b, c(\AA)$ & $17.709(13), 10.345(9), 28.39(3)$ \\
\hline$V\left(\AA^{3}\right)$ & $5202(8)$ \\
\hline$Z$ & 8 \\
\hline Radiation type & Mo $K \alpha$ \\
\hline$\mu\left(\mathrm{mm}^{-1}\right)$ & 0.63 \\
\hline Crystal size $(\mathrm{mm})$ & $0.14 \times 0.11 \times 0.11$ \\
\hline \multicolumn{2}{|c|}{ Data collection } \\
\hline Diffractometer & Bruker $A P E X$-II CCD \\
\hline Absorption correction & $\begin{array}{c}\text { Multi-scan } \\
\text { twinabs bruker axs }\end{array}$ \\
\hline$T_{\min }, T_{\max }$ & $0.684,0.746$ \\
\hline $\begin{array}{l}\text { No. of measured, independent and } \\
\text { observed }[I>2 \sigma(I)] \text { reflections }\end{array}$ & $69032,7329,5139$ \\
\hline$R_{\text {int }}$ & 0.108 \\
\hline$(\sin \theta / \lambda)_{\max }\left(\AA^{-1}\right)$ & 0.696 \\
\hline \multicolumn{2}{|c|}{ Refinement } \\
\hline$R\left[F^{2}>2 \sigma\left(F^{2}\right)\right], w R\left(F^{2}\right), S$ & $0.049,0.100,1.07$ \\
\hline No. of reflections & 7329 \\
\hline No. of parameters & 344 \\
\hline H-atom treatment & H-atom parameters constrained \\
\hline & $\begin{array}{c}c w=1 /\left[\sigma^{2}\left(F_{\mathrm{o}}^{2}\right)+(0.0215 P)^{2}+12.1196 P\right] \\
\text { where } P=\left(F_{\mathrm{o}}^{2}+2 F_{\mathrm{c}}^{2}\right) / 3\end{array}$ \\
\hline$\left.\Delta\rangle_{\max }, \Delta\right\rangle_{\min }\left(\mathrm{e} \AA^{-3}\right)$ & $1.07,-0.93$ \\
\hline
\end{tabular}

Computer programs: Bruker APEX2, Bruker SAINT, SHELXS97 (Sheldrick 2008), SHELXL2014 (Sheldrick 2014), Bruker SHELXTL. 


\section{References}

1. Pangborn, A. B.; Giardello, M. A.; Grubbs, R. H.; Rosen, R. K.; Timmers, F. J. Safe and Convenient Procedure for Solvent Purification. Organometallics 1996, 15, 15181520.

2. Russell, S. K.; Lobkovsky, E.; Chirik, P. J., Iron-Catalyzed Intermolecular $[2 \pi+2 \pi]$ Cycloaddition. J. Am. Chem. Soc. 2011, 133 (23), 8858-8861.

3. Kennedy, C. R.; Zhong, H.; Joannou, M. V.; Chirik, P. J., Pyridine(diimine) Iron Diene Complexes Relevant to Catalytic [2+2]-Cycloaddition Reactions. Adv. Synth. Catal. 2020, 362 (2), 404-416.

4. Wreford, S. S.; Whitney, J. F., Magnesium butadiene as a reagent for the preparation of transition-metal butadiene complexes: molecular structure of bis(.eta.-butadiene)[1,2bis(dimethylphosphino)ethane]hafnium. Inorg. Chem. 1981, 20 (11), 3918-3924.

5. Small, B. L.; Brookhart, M.; Bennett, A. M. A., Highly Active Iron and Cobalt Catalysts for the Polymerization of Ethylene. J. Am. Chem. Soc. 1998, 120 (16), 4049-4050.

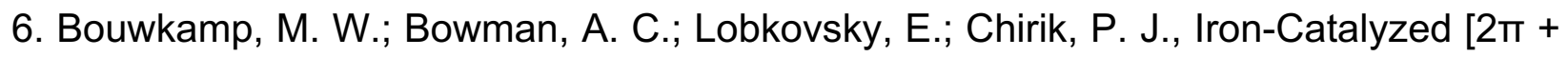
$2 \pi]$ Cycloaddition of $\alpha, \omega$-Dienes: The Importance of Redox-Active Supporting Ligands. J. Am. Chem. Soc. 2006, 128 (41), 13340-13341.

7. Schmidt, R.; Welch, M. B.; Palackal, S. J.; Alt, H. G., Heterogenized iron(II) complexes as highly active ethene polymerization catalysts. J. Mol. Catal. A. Chem. 2002, 179 (1), 155-173.

8. Zhang, J.; Gandelman, M.; Herrman, D.; Leitus, G.; Shimon, L. J. W.; Ben-David, Y.; Milstein, D., Iron(II) complexes based on electron-rich, bulky PNN- and PNP-type ligands. Inorg. Chim. Acta 2006, 359 (6), 1955-1960.

9. Schmiege, B. M.; Carney, M. J.; Small, B. L.; Gerlach, D. L.; Halfen, J. A., Alternatives to pyridinediimine ligands: syntheses and structures of metal complexes supported by donor-modified a-diimine ligands. Dalton Trans. 2007, (24), 2547-2562.

10. Çetinkaya, B.; Çetinkaya, E.; Brookhart, M.; White, P. S., Ruthenium(II) complexes with 2,6-pyridyl-diimine ligands: synthesis, characterization and catalytic activity in epoxidation reactions. J. Mol. Catal. A. Chem. 1999, 142 (2), 101-112.

11. Ion Prisecaru, WMOSS4 Mössbauer Spectral Analysis Software, www.wmoss.org, 2009-2016.

12. Perrin, C. L.; Dwyer, T. J., Application of two-dimensionaL NMR to kinetics of chemical exchange. Chem. Rev. 1990, 90 (6), 935-967. 
13. G. te Velde, F. M. Bickelhaupt, E. J. Baerends, C. F. Guerra, S. J. A. van Gisbergen, J. G. Snijders, T. Ziegler, Chemistry with ADF. J. Comput. Chem. 2001, 22, 931-967.

14. A. D. Becke, Density-functional exchange-energy approximation with correct asymptotic behavior. Phys. Rev. A 1988, 38, 3098-3100.

15. J. P. Perdew, A. Zunger, Self-interaction correction to density-functional approximations for many-electron systems. Phys. Rev. B 1981, 23, 5048-5079.

16. J. P. Perdew, Density-functional approximation for the correlation energy of the inhomogeneous electron gas. Phys. Rev. B 1986, 33, 8822-8824.

17. J. P. Perdew, Erratum: Density-functional approximation for the correlation energy of the inhomogeneous electron gas. Phys. Rev. B 1986, 34, 7406-7406.

18. S. H. Vosko, L. Wilk, M. Nusair, Accurate spin-dependent electron liquid correlation energies for local spin density calculations: A critical analysis. Can. J. Phys. 1980, 58, $1200-1211$.

19. C. Lee, W. Yang, R. G. Parr, Development of the Colle-Salvetti correlation-energy formula into a functional of the electron density. Phys. Rev. B 1988, 37, 785-789.

20. B. Miehlich, A. Savin, H. Stoll, H. Preuss, Results obtained with the correlation energy density functionals of Becke and Lee, Yang and Parr. Chem. Phys. Lett. 1989, 157, 200206.

21. E. van Lenthe, E. J. Baerends, J. G. Snijders, Relativistic two-component Hamiltonians. J. Chem. Phys. 1993, 99, 4597.

22. S. Grimme, J. Antony, S. Ehrlich, H. Krieg, A consistent and accurate ab initio parameterization of density functional dispersion correction (DFT-D) for the 94 elements H-Pu. J. Chem. Phys. 2010, 132, 154104.

23. Schrödinger Release 2020-2: Jaguar, Schrödinger, LLC, New York, NY (2020)

24. Bochevarov, A. D. et al. Jaguar: a high-performance quantum chemistry software program with strengths in life and materials science. Int. J. Quantum Chem. 2013, 113, 2110-2142.

25. S. T. Soda, Y. Kitagawa, T. Onishi, Y. Takano, Y. Shigeta, H. Nagao, Y. Yoshioka, K. Yamaguchi. Ab initio computations of effective exchange integrals for $\mathrm{H}-\mathrm{H}, \mathrm{H}-\mathrm{He}-\mathrm{H}$ and $\mathrm{Mn}_{2} \mathrm{O}_{2}$ complex: comparison of broken-symmetry approaches. Chem. Phys. Lett. 2000, 319, 223-230.

26. F. Neese. Prediction of Molecular Properties and Molecular Spectroscopy with Density Functional Theory: From Fundamental Theory to Exchange-Coupling. Coord. Chem. Rev. 2009, 253, 526-563. 
27. Tao, J. M., Perdew, J. P., Staroverov, V. N., \& Scuseria, G. E. Climbing the density functional ladder: nonempirical meta-generalized gradient approximation designed for molecules and solids. Phys. Rev. Lett. 2003, 91, 146401.

28. Staroverov, V. N., Scuseria, G. E., Tao, J. \& Perdew, J. P. Comparative assessment of a new nonempirical density functional: molecules and hydrogen-bonded complexes. $J$. Chem. Phys. 2003, 119, 12129. [Erratum] 2003, 121, 11507(E).

29. Cirera, J., Via-Nadal, M., \& Ruiz, E. Benchmarking density functional methods for calculation of state energies of first row spin-crossover molecules. Inorg. Chem. 2018, 57, 14097-14105.

30. Hay, J. P., \& Wadt, W. R. Ab initio effective core potentials for molecular calculations. Potentials for K to Au including the outermost core orbitals. J. Chem. Phys. 1985, 82, 299-310. 